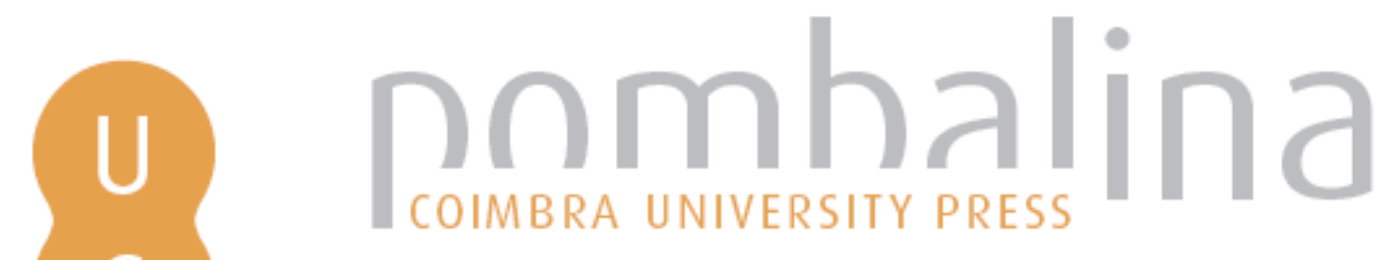

\title{
Vidas Paralelas: Teseu e Rómulo
}

Autor(es): $\quad$ Plutarco

Publicado por: Centro de Estudos Clássicos e Humanísticos

URL

persistente: URI:http://hdl.handle.net/10316.2/2412

DOI: $\quad$ DOI:http://dx.doi.org/10.14195/978-989-721-065-5

Accessed : $\quad$ 26-Apr-2023 14:06:30

A navegação consulta e descarregamento dos títulos inseridos nas Bibliotecas Digitais UC Digitalis, UC Pombalina e UC Impactum, pressupõem a aceitação plena e sem reservas dos Termos e Condições de Uso destas Bibliotecas Digitais, disponíveis em https://digitalis.uc.pt/pt-pt/termos.

Conforme exposto nos referidos Termos e Condições de Uso, o descarregamento de títulos de acesso restrito requer uma licença válida de autorização devendo o utilizador aceder ao(s) documento(s) a partir de um endereço de IP da instituição detentora da supramencionada licença.

Ao utilizador é apenas permitido o descarregamento para uso pessoal, pelo que o emprego do(s) título(s) descarregado(s) para outro fim, designadamente comercial, carece de autorização do respetivo autor ou editor da obra.

Na medida em que todas as obras da UC Digitalis se encontram protegidas pelo Código do Direito de Autor e Direitos Conexos e demais legislação aplicável, toda a cópia, parcial ou total, deste documento, nos casos em que é legalmente admitida, deverá conter ou fazer-se acompanhar por este aviso.

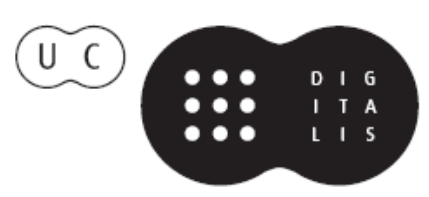


Colecção Autores Gregos e Latinos

SÉrie TeXTos

\section{Plutarco}

\section{Vidas Paralelas Teseu e Rómulo}

TRADUÇÃO DO GREGO, INTRODUÇÃO E NOTAS

DELFIM F. LeÃo Maria do Céu Fialho 
Série "Autores Gregos e Latinos -

TRADUÇÃO, INTRODUÇÁO E COMENTÁRIO”

ISSN: 2183-220X

Apresentação: Esta série procura apresentar em língua portuguesa obras de autores gregos, latinos e neolatinos, em tradução feita diretamente a partir da língua original. Além da tradução, todos os volumes são também caraterizados por conterem estudos introdutórios, bibliografia crítica e notas. Reforça-se, assim, a originalidade científica e o alcance da série, cumprindo o duplo objetivo de tornar acessíveis textos clássicos, medievais e renascentistas a leitores que náo dominam as línguas antigas em que foram escritos. Também do ponto de vista da reflexão académica, a coleçáo se reveste no panorama lusófono de particular importância, pois proporciona contributos originais numa área de investigaçáo científica fundamental no universo geral do conhecimento e divulgaçáo do património literário da Humanidade. 
(Página deixada propositadamente em branco) 
Volume integrado no projecto

Plutarco e os fundamentos da identidade europeia

e financiado pela Fundação para a Ciência e a Tecnologia.

Investigador responsável pelo projecto: Delfim Ferreira Leão. 


\section{Plutarco}

\section{Vidas Paralelas: Teseu e Rómulo}

TraduÇấo do GREGo, INTROdUÇÃo E NOTAS DE

Delfim F. Leấo

Universidade de Coimbra

Maria do Céu Fialho

Universidade de Coimbra

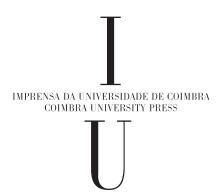


Autor: Plutarco

Título: Vidas Paralel as - Teseu e Rómulo

Traduçấo do grego, introdução e notas: Delfim F. LeÃo e Maria do Céu Fialho

Editor: Centro de Estudos Clássicos e Humanísticos

e Imprensa da Universidade de Coimbra

EDIÇÃO: 1a / 2008

Concepção Gráfica: Rodolfo Lopes

Obra REALIZADa No ÂMbito Das actividades Da UI\&D

Centro de Estudos Clássicos e Humanísticos

\author{
Universidade DE CoImbra \\ FACULdADE DE LETRAS \\ TeL.: 239859981 | FAX: 239836733 \\ 3000-447 CoImbra
}

ISBN: 978-989-8281-03-6

ISBN Digital: 978-989-721-065-5

DOI: http://dx.doi.org/10.14195/978-989-721-065-5

Depósito Legal: 278951/08

Obra Publicada com o Apoio de:

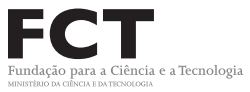

\title{
SoPlutarco
}

Sociedade Portuguesa de Plutarco

POCI $/ 2010$ 


\section{ÍNDICE}

$\begin{array}{ll}\text { Nota INAUgural } & 6\end{array}$

INTRODUÇÃo GERAL 9

$\begin{array}{ll}\text { Vida de TESEU } & 17\end{array}$

INTRODUÇÃO 19

VIDA DE TESEU

VIDA DE RÓMULO 95

INTRODUÇÃO $\quad 97$

VIDA DE RÓMULO 111

COMPARAÇÁO ENTRE TESEU E RÓMULO 175

$\begin{array}{ll}\text { BIBLIOGRAFIA } & 185\end{array}$ 


\section{Nota INAUguraL}

Com a tradução das Vidas Paralelas dos dois heróis fundadores de Atenas e Roma se inicia esta colecção de autores gregos e latinos. O Centro de Estudos Clássicos e Humanísticos realiza, agora, a etapa inaugural de um projecto de publicação de textos gregos e latinos, em tradução, que visa difundir obras que foram e são determinantes na construção de um processo de comunicação e construção referencial e identitária.

Não é fortuita a escolha das biografias de Teseu e Rómulo, postas a par por Plutarco, para inaugurar esta série. É que nela colaboram, estreitamente, a UI\&D$\mathrm{CECH}$ e o Projecto de Investigação Plutarco e os fundamentos da identidade europeia, coordenado pelo Investigador Doutor Delfim Ferreira Leão e que, como tal, será responsável por toda a linha de publicaçôes da obra traduzida de Plutarco. Ao Projecto se deve este balanço inicial, o apoio de tratamento informático dos textos, através dos seus Bolseiros, e o financiamento da publicação no que toca a obra do erudito de Queroneia e de que este é apenas o primeiro volume apresentado.

Outros autores gregos e latinos, outros textos escritos em Grego Antigo ou em Latim, e que constituem o património da nossa cultura, serão também acolhidos nesta série que, esperamos, conheça um processo de rápido e sólido crescimento e difusão.

A Coordenadora Científica do Centro de Estudos Clássicos e Humanísticos da Universidade de Coimbra Maria do Céu Fialho 


\section{As Vidas dos Dois Fundadores}

O proémio das Vidas Paralelas de Teseu e Rómulo (Thes. 1.1-3) é um passo justamente célebre, na medida em que, nestes parágrafos iniciais, Plutarco mostra estar bem consciente dos problemas acrescidos que implicava discutir figuras cuja existência se afastava da factualidade histórica, para aproximar-se de matérias geralmente mais aptas a serem tratadas por poetas e mitógrafos, terreno propício à efabulação e à lenda. $\mathrm{O}$ autor começa, aliás, por expor essa dificuldade através de um significativo paralelismo com a geografia, recordando que a operação que se prepara para iniciar equivale, de alguma forma, às notas explicativas que os cartógrafos escrevem à margem dos mapas, quando se referem a zonas cujo conhecimento não dominam. É desse terreno movediço da archaiologia que Plutarco reconhece estar agora a aproximar-se, depois de publicar as Vitae de Licurgo e Numa. No entanto, a fim de minimizar os riscos de uma empresa que poderia afigurar-se temerária aos olhos de 
um leitor mais crítico, o biógrafo compromete-se ao esforço metodológico de submeter o passado mítico a um processo de racionalizaçáo, ${ }^{1}$ que permita revestir os relatos fabulosos de uma aceitável aparência histórica (Thes. 1. 5):

Seja-me, então, permitido submeter o elemento mítico (to mythodes) à depuração da razão (logoi) de modo a assumir, assim, uma perspectiva de história.

Esta abertura das Vitae serve, igualmente, de justificação para a escolha do par Teseu-Rómulo, seleccionado para ilustrar a origem das duas cidades mais marcantes da Antiguidade Clássica: Atenas e Roma. De resto, elas simbolizam, metaforicamente, o regime democrático e o império romano (tal como o biógrafo o conhecia na viragem do séc. I para o II da nossa Era) e cujos heróis fundadores representam ainda, como veremos, enquanto expressão de uma espécie de 'genoma étnico', as características civilizacionais que hão-de marcar Atenienses e Romanos. A selecção das figuras a retratar não era indiferente, pois embora Teseu já tivesse, ao menos desde o séc. V a.C., contornos 'históricos' e políticos bastante definidos e fosse a incarnação por excelência do espírito ático, a verdade é que alguns autores, antes de Plutarco, preferiam ver em Licurgo (o lendário criador da constituição espartana) uma personalidade naturalmente mais talhada para alinhar com

${ }^{1}$ Sobre as marcas do racionalismo de Plutarco nas biografias de Teseu e de Rómulo, vide sistematização de Ampolo (1993) xi-xvii. Mais adiante, essa questáo será retomada. 
Rómulo enquanto símbolos de naçôes com grandes capacidades bélicas e com uma constituição bastante estável. ${ }^{2}$ Para mais, Teseu não fora propriamente o fundador de Atenas, mas antes o responsável pelo sinecismo de várias povoaçóes já existentes, se bem que tenha sido essa agregação o factor que potenciaria a afirmação da Ática como berço de uma importante pólis. Quanto a Rómulo, os antigos viam nele efectivamente o fundador de Roma, numa data que situavam em meados do séc. VIII a.C., se bem que também eles se apercebessem de algumas das dificuldades cronológicas criadas por esta forma de organizar o passado, em especial no que se referia à articulação com os relatos da viagem de Eneias até ao Lácio. Uma vez que, tradicionalmente, a guerra de Tróia era colocada à volta do séc. XII a.C., Eneias teria fundado Lavínio pouco depois e, por conseguinte, os gémeos não poderiam estar ligados a esse herói por um laço de parentesco próximo, na medida em que, entre as duas geraçóes, mediavam cerca de quatrocentos anos. Ora esse lapso cronológico vai ser preenchido pela dinastia dos reis albanos, iniciada por Ascânio, filho de Eneias, ao fundar Alba Longa. Este pormenor mostra que a saga de Tróia não pertence ao núcleo originário das lendas fundacionais e tem, por conseguinte, uma génese diferente, ligada ao mundo heróico da epopeia. Em todo o caso, o papel de Eneias acaba por ser secundário para os nossos objectivos, na medida em que a escolha de Plutarco recaiu sobre a vertente da lenda mais

${ }^{2}$ E.g. Cícero, Rep. 2.9.15; Dionísio de Halicarnasso, Ant. Rom. 2.23.3. 
genuinamente romana e é essa, portanto, que agora nos interessa.

Assim se compreende que Teseu seja, primeiramente, designado como oikistes, 'fundador', e Rómulo como pater, 'pai', designação que traduz uma relação visceral, bem mais profunda que aquele termo, com a cidade fundada. ${ }^{3}$ Para fazer vénia à tradição de um Teseu oikistes de Atenas, Plutarco utilizou tal recurso, introduzindo uma diferença de grau no papel de fundador, e assim preparou o terreno para realçar a distância entre a actuação do filho de Egeu e a do rebento de Reia Sílvia através dos verbos utilizados. Teseu 'congregou' (synoikise) Atenas, enquanto Rómulo fundou, 'construiu' (ektise) Roma. ${ }^{4}$

$\mathrm{O}$ verbo ktizo traduz uma acção de alcance bem mais profundo que o primeiro termo, pois é criação a partir do nada, lançar de fundamentos. Implica, também, uma concepção prévia de conjunto e a sua realização, com uma solidez que é garantia de estabilidade e perdurabilidade. Synoikizo, por seu turno, supóe reconversão, abandono do espaço ou hábitos de origem e criação de um espaço e normas comuns - Teseu terá que destruir primeiro os pritaneus locais para poder impor um pritaneu comum. ${ }^{5}$

A eficácia do seu empreendimento decorrerá, assim, da capacidade humana de fazer perdurar um projecto, mediante o exercício continuado de um sábio

\footnotetext{
${ }^{3}$ Thes. 1. 5 .

${ }^{4}$ Ibid. 2. 2.

${ }^{5}$ Ibid. 24. 3.
} 
equilíbrio. $\mathrm{O}$ que pede a intervenção decidida de um governante. Na synkrisis das biografias de ambas as figuras, Plutarco decidir-se-á, definitivamente, pela supremacia de Rómulo, que prepara desde esta primeira etapa.

A diferença entre a acção fundadora de Teseu e de Rómulo traduzir-se-á numa diferença de raiz entre a estabilidade da aniketos Rhome ${ }^{6}$ e a aventura da contingência que a democracia ateniense conheceu. $O$ perfil de cada uma das figuras denuncia, consoante já foi exposto, a natureza e o modo de ser da obra executada por cada uma delas. E ainda no que de cada uma representa o impulso da irracionalidade e do prazer imediato - eros deixa Plutarco perceber, de forma clara, a diferença entre Teseu e Rómulo. A comparação final atesta que o herói grego, que começou por seguir o paradigma de Héracles, se foi progressivamente deixando tomar pelo império da irracionalidade e do prazer, que teve o seu cúmulo no rapto de Helena. Os interesses da cidade ficaram, entretanto, relegados para segundo plano, deixando aberto o espaço para a desordem da demagogia, por falta da presença reguladora e firme do monarca (à imagem, afinal, da alma sem o exercício regulador da razão e da virtude). Rómulo, porém, enquadra política e institucionalmente o rapto das Sabinas pelo contrato matrimonial e pela aliança entre povos - tendo, para ele, reservado apenas Hersília. Assim se converte em paradigma de comportamento, ainda que essa conversão se venha, progressiva-

${ }^{6}$ Ibid. 1.5. 
mente, a converter em dureza e inflexibilidade.

O modelo de pensamento que preside à elaboração da comparação final é de inspiração ético-política aristotélica: o fio condutor da acção ideal situa-se in medio. Os desvios para um ou outro lado correspondem a falhas comportamentais, individuais e colectivas (tendo em conta o carácter metonímico do perfil e itinerário de cada uma das Vidas dos fundadores). Ainda assim, o desvio representado por Rómulo-Roma (o despotismo decorrente do egoísmo e da dureza) é abrandado por esse enquadramento de comportamentos impulsivos ao serviço das instituições e da própria estabilidade do Estado.

Uma nota final se nos impóe registar: para realizar a tradução, adoptou-se como texto de referência a edição estabelecida por K. Ziegler, Plutarchi Vitae Parallelae (Leipzig, Teubner, I959-I97I).

As notas ao texto visam esclarecer o público em geral sobre alguns aspectos fundamentais da cultura clássica e chamar a atenção para os grandes problemas levantados pela análise e interpretação das Vitae destes heróis fundadores. O leitor interessado em informação mais pormenorizada poderá consultar a sugestão bibliográfica apresentada no final deste volume.

Maria do Céu Fialho é a responsável pela introdução, tradução do grego e notas à Vida de Teseu. Delfim F. Leão tratou da parte relativa à Vida de Rómulo e à Comparação entre Teseu e Rómulo. 
VIDA DE TESEU 


\section{INTRODUÇÃO}

Os princípios expostos no proémio às Vidas $\mathrm{Pa}$ ralelas dos dois fundadores cumprem-se na biografia de Teseu, pela aplicação metodológica, por parte de Plutarco, de múltiplos processos de racionalização ao espólio de informaçôes e versóes tradicionais diversas de que dispóe. ${ }^{1}$

A contraposição, ao longo da Vita de Teseu, de fontes documentais, ou a enumeração das que se corroboram entre si atesta que Plutarco concebeu o prólogo dentro dos moldes retóricos próprios do intróito a obras históricas. ${ }^{2}$ Não se trata, apenas, de sublinhar a metodologia de racionalização sistemática, mas de proteger o seu autor de críticas de imprecisão.

E se a extensão do tempo envolve e obscurece os acontecimentos mais remotos, a história de acontecimentos

${ }^{1}$ Vide AMPOLO (1993) xii sqq.: quando Plutarco se confronta com duas versóes opostas segue a mais verosímil e mais atestada (o que o próprio escritor refere em Thes. 31,2) ; essa sua atitude leva-o a silenciar episódios famosos da vida de Teseu, ou a fazer uma alusão racionalizada, como acontece com muito do que respeita à expedição a Creta. A mesma restrição do maravilhoso ocorre com o episódio tradicional da descida ao Hades com Pirítoo, na mesma linha da tendência os atidógrafos. Por vezes, perante várias versôes igualmente verosímeis, Plutarco limita-se a reproduzi-las. É sistemática a desconfiança nos poetas, sobretudo cómicos, e, entre os trágicos, sobretudo Eurípides. A versão dos poetas só é aceite quando confirmada por outras fontes. Um outro traço do racionalismo de Plutarco apontado por Ampolo é a sua preferência por versōes da tradiçấo que se liguem à instituiçáo de um culto testemunhado pela sua sobrevivência ou pela existência de lugares onde se celebrou no passado.

${ }^{2}$ Op. cit. pp.X-XI. 
mais próximos confronta-se, no entanto, com dificuldades que lhe são peculiares, como a sua distorção, subjectiva e premeditada, operada pelos poetas - essencialmente os de índole satírica, levados pelo princípio de concessão ao gosto das massas, para delas colher aplausos. Assim o reconhece Plutarco na Vida de Péricles (13. 16): ${ }^{3}$

Assim se vê até que ponto é árdua e difícil para o historiador a tarefa de apurar a verdade. Todo aquele que viver depois dos acontecimentos de que se ocupar conte sempre com a acção veladora do tempo a ocultar-lhe o conhecimento dos factos, mas a história de feitos e vidas de contemporâneos corrompe e distorce a verdade por via de ódios e malquerenças ou com o intuito de agradar e lisonjear.

A aproximação de Teseu a Rómulo justifica-se, antes de qualquer outro motivo, pelo facto de ambas as figuras estarem associadas aos primórdios da duas cidades que se equivalem - Atenas e Roma.

Teseu é, primeiramente, designado como oikistes, fundador, e Rómulo por pater, designação que traduz uma relação visceral, bem mais profunda que aquele termo, com a cidade fundada. ${ }^{4} \mathrm{Na}$ synkrisis das biografias de ambas as figuras, Plutarco decidir-se-á pela supremacia de Rómulo, que prepara desde esta primeira etapa.

A diferença entre a acção fundadora de Rómulo e a de Teseu traduz-se numa diferença de raiz entre a

${ }^{3} \mathrm{O}$ passo inscreve-se numa sequência em que Plutarco aludira aos efeitos causados pela comédia.

${ }^{4}$ Thes. 1. 5 . 
estabilidade da aniketos Rhome e a aventura da contingência que a democracia ateniense conheceu. $\mathrm{O}$ perfil dos dois biografados transporta a natureza e o modo de ser da obra executada por cada uma deles.

Ocupar-me-ei, na introdução à biografia traduzida do construtor de Atenas, especificamente, das linhas mestras que configuram o seu carácter e que pautam a sua acção em Plutarco, o que me levará, necessariamente, a considerar o modo como Plutarco utilizou os dados da tradição sobre este herói fundador, em correlação com a sua perspectiva sobre os fundamentos e qualidades da obra criada - o sinecismo e a democracia ateniense.

A figura suscita franca controvérsia, já no que diz respeito à sua origem, já no que toca os seus traços constitutivos. ${ }^{6}$ É bem provável que Teseu tivesse sido, primordialmente, um herói local do espaço rural do nordeste da Ática.

Maratona e Afidnas constituem, de facto, o cenário onde se desenrolam alguns dos episódios mais antigos do mito, como a luta contra o touro, ou o ocultamento de Helena, raptada ainda criança. Da ligação de Teseu a Maratona constitui ainda eco a decoração da Stoa poikile em Atenas, consoante a descreve Pausânias, 1. 15. 3. Aí se encontrava representado o herói, saindo da terra para combater os Persas em Maratona. A cena é paralela à que descreve Heródoto a propósito

${ }^{5}$ Ibid. 1. 5.

${ }^{6}$ Sou particularmente sensível à tese de WALKER (1995) 9 ss., na esteira de HERTHER (1936) 177-239. 
da tentativa persa de tomar os tesouros do santuário de Delfos - dois heróis locais, Fílaco e Autónoo, erguem-se dos seus túmulos sagrados, para ajudar a escorraçar o inimigo do território. ${ }^{7}$

O nascimento mítico de Teseu em Trezena poderá, então, corresponder a uma fase posterior de expansão do conhecimento e acolhimento do herói, se tivermos em conta que, anteriormente à fixação dos Dórios na região, parecem ter aí residido Iónios - naturalmente vindos do norte.

Datam do séc. VIII a. C., ao que parece, várias trípodes de bronze, encontradas em Olímpia, e onde se vê representado o Minotauro, sob a característica forma que posteriormente se lhe reconhece na arte figurativa, com corpo humano e cabeça taurina. ${ }^{8}$ Estando o mito do Minotauro ligado a Atenas pelo tributo humano que esta cidade enviava para Creta e pelo papel libertador de Teseu, esta representação no bronze, (ainda que nela não haja indícios de um contexto de luta ou da presença do vencedor do Minotauro), pode fazer pensar que a cidade já havia, ao tempo, adoptado o herói como seu. A mais antiga representação da luta entre o herói e o monstro do Labirinto encontra-se na ornamentação pictórica de uma ânfora cicládica da primeira metade do séc. VII a. C., que se encontra no museu de Basileia.

De qualquer modo, da expansão da aceitação do herói por espaço helénico decorre uma singular genealogia e

\footnotetext{
7 Heródoto, 8. 38-39.

${ }^{8}$ Vide WALKER (1995) 16.
} 
origem geográfica de carácter mítico - aquele que se virá a converter no herói tutelar de Atenas por excelência, no criador do sinecismo e na figura em que se vão projectando os próprios valores de uma Atenas idealizada como, a título de exemplo, nas Suplicantes de Eurípides ou no Coloneus sofocliano, é filho da união entre Egeu, o descendente da autoctonia ática, e de uma mulher da casa de Pélops - dórica, pois, por excelência. ${ }^{9}$ União que Plutarco explica por ter sido consumada pelo engano (hapate) ou pelo acaso de um oráculo mal compreendido. ${ }^{10}$

Deparamo-nos, pois, com uma origem 'descentrada' em relação a Atenas do filho do monarca ateniense: ele terá que percorrer o caminho de Trezena até Atenas, até ao reconhecimento paterno e à adopção pela cidade. Esse caminho de aventuras e perigos é decalcado sobre as aventuras e perigos vividos por Héracles, conforme Plutarco reconhece.

O biógrafo apresenta-nos um Teseu criado em segredo, cuja infância e adolescência se desenrolam sob o signo de uma falsa referência paterna - a de Poséidon para posteriormente vir a ser confrontado, no despontar da sua virilidade, com a verdadeira identidade do pai - a de um pai humano - através dos sinais de reconhecimento, ocultos pelo rochedo que conseguiu remover. O herói conhece, assim, a sua real identidade. No entanto, ambas as referências continuam a pesar, naquilo a

${ }^{9}$ WALKER (1995) cap. 2, mostra como o perfil da figura sofre, mesmo no séc. V, oscilações que são fruto da projecção de concepçóes de governo e do papel do governante na época, ou do questionamento das estruturas políticas e da sua eficácia.

${ }^{10}$ Thes. 3. 5. 
que Walker designa por paternidade dupla ou ambígua, mesmo por detrás da versáo racionalizada de Plutarco. ${ }^{11}$ Tal é perceptível quando Teseu adopta, para a afirmação da sua imagem, um critério de exigência de comportamento e de excelência, imposto simultaneamente pelo facto de ser publicamente considerado como filho de um deus e pelo modo como se quer vir a apresentar perante o seu verdadeiro pai. ${ }^{12}$ Do mesmo modo, ao chegar à Ática e encontrar os Fitálidas, Teseu pede para ser purificado (12.1) pelo facto de ter morto Sínis, segundo Pausânias (1. 37. 4), que seria filho de Poséidon. Este pedido denuncia vestígios de uma versão de Teseu filho de Poséidon - logo, meio-irmão do assassinado.

O herói escolhe o caminho por Atenas por terra e não por mar, por ser o mais difícil e por poder aí evidenciar a sua coragem, determinando, deste modo, o efeito do seu aparecimento público na cidade e o paralelismo dos seus feitos com os de Héracles.

A multiplicidade de aspectos da figura de Teseu deu azo a explicaçóes diversas sobre a sua verdadeira dimensão original: entre outras a de réplica de Héracles, de herói iónico, de herói iniciático de ritos de passagem da efebia à maturidade - de que seria eco o episódio da aventura em Creta e do resgate.

11 (1995). cap. 3. Em Baquílides, nota o autor, Teseu é filho de Poséidon. Mas dessa filiação há ainda vestígios, mesmo em contextos posteriores, como no Hipólito de Eurípides. Só assim faz sentido o motivo dos três desejos cuja satisfação Poséidon proporciona a Teseu.

${ }^{12}$ Thes. 7. 2. A que se junta, ainda, a emulação com o exemplo de Héracles. 
Teseu em Plutarco parece-me concentrar simultaneamente traços que atestam a aglutinaçáo de leituras e projecçóes diversas na figura, conferindo-lhe uma complexidade e contradiçóes que se tornam inalienáveis do perfil com que nos surge. Se a expedição a Creta pode, de facto, ser projecção de um ritual iniciático, centrífugo, a partir de Atenas, para depois à cidade regressar, na plena afirmação e pujança dos jovens, não o é menos o caminho de Trezena até Atenas, do espaço da infância e da esfera materna até à presença paterna e ao reconhecimento - caminho feito sem um nome assumido, como Plutarco assinala, em que várias provas se pôem ao jovem. Com elas se confronta e as vence, para, finalmente, ostentar perante Egeu, num acto público o banquete -, a arma paterna, sinal que o levará a ser reconhecido, sem que ele necessite dar-se a conhecer.

Sobre a educação de Teseu, pouco nos diz Plutarco. Apenas que esteve aos cuidados do avô paterno, Piteu, sophotatos, mas detentor de uma sabedoria prática que, certamente, não é alheia ao engenho com que persuadiu Egeu a aproximar-se de Etra, e que teria transmitido ao neto como metis, demonstrada nos feitos em Creta e mais própria do protótipo do herói iónico.

Do pedagogo de Teseu Plutarco apenas refere o nome - Cónidas ${ }^{13}$ - e não o tipo de acção educativa. Ora o que verdadeiramente influenciou de modo determinante o jovem Teseu e modelou o seu desejo de acção foi o exemplo paradigmático de Héracles, transmitido em

13 Thes. 4. 
relatos que lhe suscitaram uma admiração inflamada. É esta a motivação para a escolha do caminho até Atenas: ${ }^{14}$

Do mesmo modo a admiraçáo pelo valor de Héracles levava Teseu a sonhar de noite com os seus feitos e de dia, dominado e exaltado pelo desejo de emulaçáo, pensava em praticar feitos semelhantes.

A aproximação de Teseu à figura de Héracles é modelada pelo erudito de Queroneia à luz das suas convicçôes acerca do papel educativo do exemplo das acçôes ilustres, operado sobre a alma humana e a que alude com frequência nos seus escritos de filosofia moral.

Ao exemplo educativo dedica um dos mais belos e expressivos passos das Vitae - a abertura da biografia de Péricles: ${ }^{15}$

Pois tal como a cor mais benéfica para os olhos é aquela cujo brilho e doçura estimulam e tonificam a visão, assim mesmo se torna necessário encaminhar o pensamento para a contemplaçáo de espectáculos que, por efeito do prazer que suscitam, conduzem aquele ao bem que lhe é intrínseco.

Tais espectáculos consistem nas acçóes nascidas da virtude e despertam, nos homens que os observam, um sentimento de emulação e o desejo de os imitar.

As obras nascidas da arete convertem-se, platonicamente num equivalente ao bem, que se impóe, pela sua beleza, e que fascina a alma humana a contemplá-lo. Tais

14 Thes. 6. 9.

15 1. 3-4. 
obras tornam-se, assim, motor da acção humana, suscitando em quem delas toma conhecimento um natural anseio de imitação (mimesis), através do sentimento de emulação e desejo de as igualar (zelos kai prothymia). ${ }^{16}$

$\mathrm{Na}$ mesma Vita, em 2. 1-2, Plutarco retoma e aprofunda este pensamento:

Não acontece necessariamente, se uma obra nos encanta pela sua beleza, que o seu autor seja digno de admiraçáo. Por isso, não há vantagem em contemplar tais obras que não provocam a emulaçáo nem o arrebatamento que suscita o desejo e o afă de as imitar. A virtude, em contrapartida, pelas acçốes que inspira, dispóe claramente à admiraçấo pelos feitos e à simultânea emulação com os seus autores.

Para o polígrafo de Queroneia essa atracção das obras da arete exercida sobre a alma em formação pressupôe nesta última uma predisposição que é também arete inata e que aspira, ao receber o estímulo de uma acção modelar que se impóe como espectáculo, a elevar-se à superioridade desta e com esta se medir, numa saudável emulação, traduzida em actos. Para desenvolver esta natural propensão, expurgada da influência de maus estímulos, tem papel decisivo a formação dada pela paideia.

Ora os perigos com que Teseu arrostou no percurso até Atenas, os malfeitores punidos e exterminados

${ }^{16}$ Quanto ao papel da emulação (zelos) como um dos componentes essenciais na formação moral das figuras das Vitae de Plutarco, e sobre o lugar que ocupa a referência a zelos NA progressão peculiar do esquema das biografias, vide PÉREZ JIMÉNEZ (1985) 100-105. 
traduzem o efeito actuante do exemplo sobre um jovem cuja predisposição para a philantropia e para a megalophrosyne se realiza em actos que têm como objectivo exercer a coragem e libertar aos viandantes os caminhos.

Essa série de aventuras aparece, assim, no relato de Plutarco, integrada no todo de um percurso conseguido, coeso, sem dispersão, até à figura paterna.

Cultivando a força do exemplo, Teseu, num impulso de generosidade, oferece-se para integrar o grupo de reféns destinado a Minos. O que suscita, por seu turno, a admiração dos atenienses pela sua grandeza de alma (phronema) e pela sua devoção ao povo (demotikon): ${ }^{17}$

Estas queixas afligiam Teseu, que entendeu ser justo não se alhear, mas antes tomar parte na sorte dos seus concidadãos, pelo que se foi oferecer espontaneamente, antes do sorteio. Aos demais pareceu admirável esta grandeza de espírito e louvaram a sua devoção ao povo...

Plutarco afasta e contradita, assim, a versão de Helânico: ${ }^{18}$

Helânico afirma, no entanto, que a cidade não tirava à sorte os jovens e as donzelas que havia de enviar, mas que era o próprio rei Minos quem vinha escolhê-los e que este escolheu à partida Teseu ... 
Porém, ao oikistes fundador de ritos, libertador de caminhos e da juventude ateniense, falta a capacidade de exercício - askesis - da razão sobre a parte irracional da alma. ${ }^{19}$ Mesmo na grandeza de espírito que o leva a arrostar com o perigo percebe-se o componente impulsivo que o força a ceder a um prazer sob a forma de eros descontrolado - o que se converterá na causa da sua ruína. Já no caminho de Trezena para Atenas essa tendência se manifesta. Plutarco denuncia-a de forma esbatida, no que respeita ao estupro de Periguna, referido de forma lacunar.

O biógrafo assinala em mais de uma dezena as mulheres tomadas à força ou seduzidas e abandonadas por Teseu até ao clímax da sua hybris de hedone, atingido com o rapto de Helena ainda criança: ${ }^{20}$

Este comportamento faz suspeitar que ele agia por violência e por prazer.

Se, para Plutarco, os males humanos não podem, frequentemente, ser imputáveis aos deuses, mas ao acaso e à acção humana que, combinada com a tyche, pode levar o homem ao sofrimento, ${ }^{21} \mathrm{o}$ filósofo entendia, certamente, o destino de Teseu como ilustração deste princípio - conforme o atesta a própria synkrisis ${ }^{22}-\mathrm{e}$ não deixa de ver no rapto de Helena uma das causas do

${ }^{19}$ Sobre a askesis como uma das principais condiçóes para alcançar a virtude, veja-se PÉREZ JIMÉNEZ (1985) 35 sqq.

${ }^{20}$ Rom. 35. 2.

${ }^{21}$ Vide PÉREZ JIMÉNEZ (1973) 101-110.

${ }^{22}$ Rom. 32. 1. 
mal-estar e da sedição (stasis) do povo ateniense contra o seu governante. ${ }^{23}$

O criador do sinecismo não soube, por uma falha estrutural do seu carácter, conferir estabilidade e solidez a um vínculo social que é a base da estrutura de uma comunidade organizada - a união conjugal. Rómulo, fundador e construtor de Roma, usou-a, em contrapartida, como pedra angular da sociedade romana e como um dos pilares da conciliação e aliança política que fortalece o estado e que deu azo à prosperidade de Roma. ${ }^{24}$

Mais ainda: como homem de acção impulsiva, o criador do sinecismo náo soube desenvolver, pelo exercício e pela pertinácia, as qualidades racionais do bom governante, mesmo como mero guardião das leis, de modo a poder dar coesão à nova configuração da Cidade. O prazer, sob a forma de eros, agiu como factor de dispersão e força centrífuga que o desenraizou de Atenas. Prometendo-lhe a isoimoiria, divide-a, na prática, em classes sem direitos equivalentes, ${ }^{25}$ prometendo-lhe uma democracia de que ele seria mero chefe na guerra $e$ guardiāo das leis (24. 2), afasta-se da cidade e deixa que o povo singre sem timoneiro, ao sabor de demagogos e dos seus próprios vícios latentes, deixa que as várias classes se digladiem entre si. ${ }^{26}$

${ }^{23}$ Thes. 31 sqq.

${ }^{24}$ Rom. 35. 2-3. Para uma melhor compreensão da importância do texto no contexto da synkrisis da bigrafia de Teseu e de Rómulo, em que se situa, veja-se ERBSE (1956) 398-424.

25 25. $1-2$.

2632.1 sqq. 
O papel do governante ideal, para Plutarco, identificado com o do monarca que age com a mesma intervenção ordenadora com que a razão opera na alma, está longe desta figura excepcional, mas marcada por contradiçóes, por falhas estruturais que determinarão o seu exílio e a sua morte, despenhando-se do alto de um rochedo.

A sua morte pode ser tida como a paradigmática imagem do desenlace do percurso existencial daquele que ao mais alto subiu para se despenhar no abismo perspectiva antropológica tão cara à poesia grega arcaica, à tragédia clássica, ${ }^{27}$ às Histórias de Heródoto.

Desprezando as versôes dos poetas, Plutarco quase nos póe, no entanto, perante um itinerário trágico de uma figura heróica. E sê-lo-ia, se a esta não faltasse o necessário reconhecimento do limite e do erro.

Concluiria, então, que parece haver, assim, entre as virtudes e fraquezas de Teseu e as virtudes e fraquezas da sua própria cidade uma estreita simbiose, uma correspondência que Plutarco teria esboçado conscientemente, de modo a que os vícios e a magnitude do criador do sinecismo assumam uma dimensão arcaica, no sentido etimológico do termo. Na praxis de Teseu transparece a etiologia das próprias fissuras e contradiçóes da democracia ateniense e no destino daquele o destino de uma cidade que conheceu um excepcional esplendor político e cultural, marcado pela philantropia e megalophrosyne, mas sem a askesis que lhe permitisse refrear a cupidez de poder e lucro.

${ }^{27}$ Veja-se, a título de exemplo, o estásimo IV de Rei Édipo. 
É que essa askesis opera através da intervenção sábia e decidida do governante, num sistema de monarquia - governante atento ao seu próprio equilíbrio moral como fonte de competência para salvaguardar a harmonia do estado que governa.

Difícil é esse equilíbrio, solicitando atenção constante, e esbatida é a fronteira que o separa da degenerescência em democracia ou em tirania. Ambas são, para Plutarco, formas de governo adulteradas, de sinal contrário, mas nascidas da mesma fonte - a perda da justa relação do governante com o poder que exerce, decorrente ou da philantropia ou da philautia $^{28}$ e que o irá converter em demagogo ou em déspota. 
VIDA DE TESEU 


\section{1. Os historiógrafos, ó Sóssio Senecião, ${ }^{1}$ re-}

metem para os confins das cartas geográficas aqueles espaços que escapam ao seu entendimento e registam, à margem, a seguinte anotação: "a partir daqui estendem-se areais sem água e infestados de feras" ou entáo "pântano sombrio", ou "gelo cítio", ou "mar gelado". 2. Ora também eu, que, para redigir as Vidas Paralelas, passei em revista ${ }^{2}$ a extensão de tempo passível de um relato verosímil e susceptível de uma investigação que se atenha a factos, bem poderia afirmar das eras que a precedem: 3. "daí para trás fica o domínio dos prodí-

${ }^{1} \mathrm{O}$ par de Vitae Teseu-Rómulo é dedicado a Sóssio Senecião, como o atesta a utilização do vocativo, de acordo com os cânones da própria dedicatória. Trata-se de uma importante figura do mundo romano do tempo dos imperadores Domiciano e Trajano. Foi amigo influente deste último, durante cujo reinado foi cônsul ordinário (99 e 107 p. C.), governador de uma província imperial, alta patente militar na segunda Guerra Dácia, na sequência do que recebeu, pelo desempenho que aí teve, os ornamenta triumphalia. Parece ser oriundo de uma província romana da parte oriental da Grécia. A sua amizade com Plutarco deve ter-se sedimentado durante a década de oitenta, quando foi questor na Grécia: AMPOLO (1993) comm. ad 1.1. Foi também amigo de Plínio-o-Moço. É referido em outras Vidas Paralelas (Dem. 1.1; 31.7 e Dio. 1.1) e Plutarco dedicou-lhe vários outros escritos. JONES (1971) 54-55, sublinha o significado desta amizade entre o romano e o polígrafo de Queroneia. Aquele teria representado um forte elo de ligação de Plutarco ao mundo romano e, ao mesmo tempo, uma espécie de síntese paradigmática dos valores gregos e romanos, já que, político e militar de sucesso, era também um homem votado às letras e à filosofia.

${ }^{2}$ A forma "passei em revista", que fiz corresponder ao aoristo grego dielthonti, como bem o observa PÉREZ JIMÉNEZ (1985) 152 n. 3, deixa perceber que outras biografias haviam já sido escritas, mas não dá margem a que se conclua que todas as outras haviam já sido compostas e que este é o último par a ser escrito. 
gios e da matéria própria dos trágicos; ocupam-no os poetas e mitógrafos e não há lugar para credibilidade ou certeza”. 4. No entanto, quando publiquei ${ }^{3}$ a vida de Licurgo, o legislador, e de Numa, o rei, não me pareceu destituído de lógica recuar até Rómulo. É que fui levado pelas minhas investigaçôes até uma época próxima da sua, enquanto me interrogava, no dizer dos versos de Ésquilo: ${ }^{4}$

Contra um homem tal, quem se atreverá?

Quem lhe irei eu contrapor? Quem terá valor para tal?

5. Pareceu-me que o fundador da bela e famosa Atenas podia confrontar-se e ser posto em paralelo com o pai da invencível e gloriosa Roma. Seja-me, entâo, permitido submeter o elemento mítico à depuração da razão de modo a assumir, assim, uma perspectiva de História. Se, no entanto, ele colidir ainda, abertamente, com o critério da credibilidade e não se enquadrar no da verosimilhança, pedirei a benevolência dos leitores e a sua aceitação indulgente desta história antiga.

${ }^{3}$ Este passo tem oferecido lugar a conjecturas várias sobre a ordem de publicação das Vidas Paralelas, como, por exemplo: será a publicação do par Licurgo-Numa anterior a Teseu-Rómulo, o que me parece mais passível de se deduzir do texto grego, ou, como supóe FLACELIERE-CHAMBRY (1957) 12 n. 2, o presente prefácio terá, provavelmente, servido de introdução aos dois pares de Vidas? Há ainda quem pense que as vidas dos dois fundadores teriam sido as últimas ou das últimas a ser compostas (STOLZ, apud AMPOLO (1993) comm. ad 1.4.

${ }^{4}$ Ésquilo, Sete contra Tebas, v. 436 e 395-396. A citação não corresponde exactamente ao texto esquiliano. 
2. 1. Pareceu-me, então, que Teseu tinha em comum, com Rómulo, um bom número de aspectos similares. Ambos vieram, de facto, ao mundo como bastardos e em segredo, e ambos foram tidos por filhos de divindades, ${ }^{5}$

ambos guerreiros, todos nós o sabemos,

2. aliando à sua força a inteligência. ${ }^{6}$ De entre as cidades mais ilustres um fundou Roma; o outro realizou o sinecismo de Atenas. Tanto um como outro levaram a cabo raptos de mulheres. 3. Nenhum deles escapou a infortúnios domésticos e a invejas familiares e diz-se que, no fim da vida, ambos tiveram desavenças com os seus concidadãos, se as tradiçóes de carácter menos poético ${ }^{7}$ algum elemento contêm que se mostre útil para apurar a verdade.

3. 1. A ascendência paterna de Teseu remonta a Erecteu $^{8}$ e aos primeiros homens autóctones. Por parte

${ }^{5}$ Iliada, 7. 281.

${ }^{6}$ Esta afirmação, como o nota PÉREZ JIMÉNEZ (1985) 154 n. 8 , quase constitui uma paráfrase de Tucídides (2.15. 2), também sobre Teseu.

7 Traduzi por "menos poético" a expressão hekista tragikos. FLACELIÈRE-CHAMBRY (1957) preferiram "moins fabuleuses". Trata-se de uma sinédoque em que, essencialmente, se fala do carácter imaginativo e pouco escourado na informação factual da poesia.

${ }^{8}$ Erecteu, o mítico rei de Atenas, era filho de Pandíon e Zeuxipa. Teve, de Praxítea, três filhos e quatro filhas; de entre aqueles, 
de sua mãe, Teseu era um Pelópida. 2. Pélops foi, de facto, o rei mais poderoso do Peloponeso, não tanto pela sua enorme riqueza como pelo número de filhos. ${ }^{9}$ Casou muitas das suas filhas com homens da mais alta estirpe e estabeleceu muitos dos seus filhos como governantes das cidades espalhadas pela região. Um deles foi Piteu, avô de Teseu, que fundou Trezena, ${ }^{10}$ uma cidade de pequenas dimensôes; por si, alcançou fama de ser o homem mais douto e mais sábio de todos os de então. 3. O carácter e o grau da sua sabedoria eram da mesma índole, ao que parece, dos da sabedoria que Hesíodo manifestou e que o tornou famoso, sobretudo no que diz respeito às sentenças dos seus Trabalhos. 4. Uma dessas sentenças, ao que se diz, é da autoria do próprio Piteu: ${ }^{11}$

seja dado ao teu amigo o salário certo.

Cécrops, por sua vez, gerou um descendente a quem deu o nome de seu pai - Pandíon (II). Este foi pai de Egeu e de Palante.

${ }^{9}$ Pélops, filho de Tântalo e Dione, logrou alcançar a mão da princesa Hipodamia, filha de Enómao de Pisa. Diferentemente da explicação dada por Tucídides (1. 9. 1-2) para a preponderância de Pélops no Peloponeso (de que é epónimo) - as riquezas trazidas da Ásia por si e pela sua descendência -, a justificação de Plutarco para tal prestígio e poder assenta na riqueza própria mas, acima de tudo, na descendência numerosa, sinal de prosperidade e de possibilidade de estabelecimento de alianças através de casamentos. Os seus filhos mais famosos foram Piteu, avô de Teseu, Atreu, pai de Agamémnon e de Menelau, e Tiestes, pai de Egisto, que matará Agamémnon.

${ }^{10} \mathrm{~A}$ cidade de Trezena situava-se na costa norte da península da Argólida, na regiáo do Nordeste do Peloponeso, à entrada do Golfo Sarónico, separada de Atenas pelas águas deste.

${ }^{11} \mathrm{O}$ preceito ocorre, deste modo formulado, em Hesíodo, Trabalhos e Dias, v. 370 . 
Isto foi asseverado também pelo filósofo Aristóteles. Eurípides, por seu turno, quando se refere a $\mathrm{Hi}$ pólito como "resultado da educação do irrepreensível Piteu", ilustra a fama de Piteu. ${ }^{12}$

5. Diz-se que Egeu, ansioso por ter descendência, recebeu da Pitonisa o famoso oráculo que o aconselhava a não ter relaçôes com mulher alguma antes de chegar a Atenas; no entanto, a ele, não lhe pareceram suficientemente claras estas palavras. Quando chegou às imediaçóes de Trezena, deu a conhecer a Piteu a resposta do deus, conforme a tinha recebido: ${ }^{13}$

Tu, que és o mais poderoso dos homens, não soltes o pé que te sai do odre antes de chegar a Atenas.

Não se sabe como Piteu terá entendido estas palavras, mas fosse pela persuasão, fosse pelo engano, levou Egeu a unir-se a Etra. 6. Consumada a união e ao saber que a jovem era a filha de Piteu, por suspeita de que ela estivesse grávida, Egeu deixou a sua espada e as suas sandálias escondidas sob uma enorme pedra que possuia uma cavidade interior, com dimensão suficiente para abrigar estes objectos. 7. Somente a Etra ele contou o que tinha feito e recomendou-lhe que, caso nascesse um filho de ambos e este, ao chegar à idade adulta,

${ }^{12}$ Eurípides, Hipólito, v. 11.

${ }^{13}$ Este oráculo, com pequenas variantes, era muito conhecido na Antiguidade. Vide FONTENROSE, The Delphic Oracle, (Berkeley and Los Angeles, Univ. of California Press, 1978) 356. 
fosse capaz de levantar a pedra e retirar o que lá estava escondido, o enviasse à sua presença, na posse daqueles objectos, sem dizer nada a ninguém e, na medida do possível, às ocultas de todos. É que, na verdade, Egeu temia seriamente os Palântidas, que conspiravam contra ele e o desprezavam por não ter descendentes, enquanto que eles eram cinquenta, todos filhos nascidos de $\mathrm{Pa}$ lante. Posto isto, retomou o seu caminho.

4. 1. Etra deu à luz um filho e há quem diga que este logo recebeu o nome de Teseu, devido à forma como foram depositados ${ }^{14}$ os sinais de reconhecimento. Outros afirmam que só mais tarde, em Atenas, ele recebeu o seu nome, quando Egeu o adoptou como filho. ${ }^{15} \mathrm{O}$ menino foi criado sob a protecção de Piteu e teve como mestre e preceptor um homem de nome Cónidas, a quem os Atenienses sacrificam ainda hoje um carneiro, na véspera das festividades em honra de Teseu, ${ }^{16}$ recordando-o e venerando-o com muito maior razão de ser do que aquela por que veneram Silânion ou Parrásio, ${ }^{17}$ por terem pintado ou esculpido a figura de Teseu.

${ }^{14}$ Gr. thesis.

${ }^{15}$ Gr. paida themenou tou Aigeos.

${ }^{16}$ Estas festividades decorriam no dia oito do Pianépsion, quarto mês do ano ático, que correspondia à segunda metade do mês de Outubro e à primeira do de Novembro.

${ }^{17} \mathrm{O}$ escultor ateniense Silânion (séc. IV a. C.) foi autor, entre a de outras figuras da mitologia grega, de uma famosa estátua em bronze de Teseu. O conhecido pintor Parrásio de Éfeso, por sua vez, (séc. V-IV a. C.) representou Teseu num quadro de sua autoria. 
5. 1. Era então ainda uso que, ao sair da infância, os jovens fossem a Delfos oferecer ao deus as primícias do seu cabelo. Também Teseu foi a Delfos - e até dizem que dele tomou o nome de Teseia o local que ainda hoje assim é chamado - mas rapou apenas a parte anterior do seu crânio, conforme era costume entre os Abantes, segundo Homero. ${ }^{18}$ E este tipo de corte passou a ser designado de 'corte à Teseu', por sua causa. 2. Foram, no entanto, os Abantes quem primeiro usou o cabelo cortado desta maneira, não por o terem aprendido dos Árabes, conforme pensam alguns, nem por imitação dos Misos, mas pelo facto de, sendo guerreiros, se exporem, de perto, ao inimigo e possuirem um treino inigualável na luta corpo a corpo, conforme o atesta Arquíloco nestes seus versos: ${ }^{19}$

3. Não haverá muitos arcos tensos, nem fundas sem conto, quando Ares ao combate na planície convocar.

Penoso há-de ser o labor da espada.

Desta luta são soberanos

Os senhores da Eubeia, famosos pela sua lança.

4. Era, pois, para não oferecerem ao inimigo por onde pudessem ser agarrados que rapavam o cabelo. Isto

${ }^{18}$ Homero refere-se aos Abantes, habitantes da ilha de Eubeia, em Ilíada, 2.536 e 4. 464. Não faz, no entanto, qualquer referência ao seu corte de cabelo. PÉREZ JIMÉNEZ (1985) 158 n. 21, conjectura, baseado em Herter, que provavelmente se trataria de um "transposição mítica de um costume ateniense". Aquele povo prehistórico teria primeiro habitado na Fócida, em Abas, e passado, posteriormente, à ilha de Eubeia.

${ }^{19}$ Frg. 3 West. 
era, decerto, o que Alexandre da Macedónia tinha em mente quando deu ordem aos seus generais para mandar cortar a barba dos Macedónios, pois ela tornar-se-ia, nas batalhas, uma presa muito fácil.

6. 1. Até àquele momento Etra guardou segredo sobre a verdadeira origem de Teseu; Piteu, por seu turno, havia divulgado a versão de que a filha tinha concebido do deus Poséidon. É que Poséidon é objecto de especial veneração por parte dos habitantes de Trezena. ${ }^{20}$ Têm-no como deus protector da cidade, a ele oferecem as primícias das suas colheitas e na sua moeda ostentam o tridente como cunho distintivo. 2. Mas quando Teseu chegou à adolescência e revelou que, aliada à força física, possuia coragem e uma declarada nobreza de espírito, assim como inteligência e compreensão, então Etra conduziu-o até junto da rocha e, depois de lhe dar a conhecer a sua origem, ordenou-lhe que tomasse os sinais de identificação do pai e navegasse rumo a Atenas. 3. Então o jovem, agarrando a rocha pela parte inferior, facilmente a levantou, mas recusou-se a empreender a viagem por mar, ainda que a travessia fosse segura e o avô e a mãe lho tivessem pedido. Com efeito, era perigoso o percurso até Atenas, feito por terra, e não havia troço algum do caminho que estivesse isento da ameaça de ladrões e de malfeitores.

${ }^{20}$ A cidade estava consagrada a Poséidon. Estrabão (8.6.14.373) diz que, por esse motivo, era também conhecida pelo nome de Poseidónia. Da tradição da paternidade de Poséidon em relação a Teseu é eco exemplificativo Eurípides, Hipólito, v. 1169-1170. 
4. Aquela época tinha, de facto, ao que parece, produzido homens que, pela força dos seus braços, pela ligeireza dos seus pés e pelo vigor dos seus corpos eram excepcionais e infatigáveis, mas que não faziam, contudo, uso dos seus dons para qualquer fim conveniente ou útil. Pelo contrário: sentiam prazer na violência e na arrogância e tiravam proveito da sua força para saciar a sua crueldade e dureza e submeter, violentar e destruir o que caísse nas suas mãos. Estavam persuadidos de que a maior parte dos homens apenas louvava o respeito e a justiça, a equidade e a filantropia devido à sua falta de coragem para cometer crimes e ao medo de ser alvo deles, e de que aquelas virtudes náo convinham a quem tivesse capacidade para preponderar.

5. Destes malfeitores, alguns bateu-os e eliminou-os Héracles, no decorrer das suas andanças; outros, porém, ao sabê-lo próximo, esconderam-se para lhe escapar e passar despercebidos e acabaram por cair no esquecimento e por levar uma vida miserável. 6. Ora quando Héracles caiu na desgraça, depois de ter morto Ífito, ${ }^{21}$ e partiu para a Lídia, onde serviu longo tempo a Ônfala como escravo - esta foi a pena que a si mesmo impôs pelo homicídio - , a Lídia desfrutou então de paz absoluta e de segurança. No território da Hélade, em contrapartida, passaram a florescer de novo e a proliferar os actos de violência, sem que houvesse alguém que os reprimisse e lhes pusesse cobro.

${ }^{21}$ Ífito, filho de Êurito, rei da Ecália, foi precipitado por Héracles, do alto de uma torre, em Tirinto. Assim este se apossou das suas éguas perdidas e duplamente quebrou os vínculos de hospitalidade. A história é conhecida do poeta da Odisseia, que a canta em 21.22.30. 
7. Era, pois, perigosa a viagem para quem tomasse o caminho por terra do Peloponeso até Atenas. Piteu, na tentativa de persuadir Teseu a viajar por mar, explicou, assim, ao neto quem era cada um dos ladrôes e malfeitores e que tipo de maus tratos infligia aos forasteiros. 8. Todavia, desde há muito, ao que parece, que a fama do valor de Héracles inflamava secretamente o jovem; falava dele com extrema frequência; escutava com a maior das atençôes quem pudesse descrever como ele era - sobretudo aqueles que o haviam visto e podiam relatar os seus feitos e reproduzir as suas palavras. 9. Para todos era então evidente este seu sentimento, semelhante ao que viria a experimentar, muito tempo depois, Temístocles, ao afirmar que o troféu de Milcíades o impedia de dormir. Do mesmo modo a admiração pelo valor de Héracles levava Teseu a sonhar de noite com os seus feitos e de dia, dominado e exaltado pelo desejo de emulação, pensava em praticar feitos semelhantes. ${ }^{22}$

${ }^{22}$ Plutarco sublinha, assim, o valor dos paradigmas de referência na paideia e na formação ética do indivíduo. Quanto ao paralelismo Héracles-Teseu, é sabido que ele foi cultivado na Atenas do séc. V, está na base do processo de idealização de Teseu como o governante que é espelho de virtudes ético-políticas - processo esse que corresponde a um movimento de propaganda política da fase de expansionismo ateniense. A Teseu se pretende dar uma dimensão pan-helénica similar à de Héracles, conferindo-lhe o perfil de herói alternativo. A popularidade e aproveitamento político da figura mítica conhece, durante a democracia de Clístenes (fim do séc. VI a. C.), um impulso, e novo impulso ao tempo de Címon. Vide WALKER (1995) 55 ss. 
7. 1. Acontecia que ambos estavam ligados por laços de sangue, uma vez que suas mães eram primas. Etra era filha de Piteu, e Alcmena, por seu turno, de Lisídice. Ora Lisídice e Piteu eram irmãos, nascidos ambos de Hipodamia e de Pélops. 2. Parecia-lhe, então, indigno e intolerável que, enquanto Héracles andava a perseguir, por toda a parte, os malfeitores, a fim de expurgar a terra e o mar, ele mesmo evitasse os confrontos que se lhe podiam deparar no caminho e empreendesse viagem por mar, como quem foge, envergonhando, assim, aquele que, de acordo com o que se dizia e com o que era voz corrente, era seu pai. E à presença do seu verdadeiro pai iria levar, como sinais de reconhecimento, umas sandálias e uma espada limpa de sangue, sem lhe apresentar, à partida, nem por actos nem por façanhas valorosas, sinais evidentes do seu nobre nascimento. 3 . Com esta disposição e estes pensamentos se pôs a caminho, no propósito de não cometer ofensas contra quem quer que fosse, mas de punir quem usasse de violência.

8. 1. E o primeiro malfeitor com que se defrontou foi Perifetes, ${ }^{23}$ na região de Epidauro. Usava uma clava para combater e, por esse motivo, o apelidavam de Clavado. Ao atacar Teseu, com a intenção de o impedir de prosseguir caminho, este matou-o. Agradoulhe a clava, tomou-a e adoptou-a como arma, passando

${ }^{23}$ Perifetes seria filho de Hefesto, segundo Apolodoro, Ovídio e Pausânias e de Anticleia (Higino dá-o como filho de Poséidon). É representado coxo, como seu pai, apoiado numa muleta ou numa clava (koryne). Ao tomar a sua clava, Teseu aproxima-se, por esta insígnia bélica, de Héracles. 
a usá-la sempre, tal como Héracles tinha feito com a pele do leão. 2. Para este último, a pele servia para demonstrar, ao ostentá-la, como era corpulenta a fera que havia vencido. Teseu demonstrava que a mesma clava que havia derrotado se tornara, nas suas máos, uma arma invencível.

3. Nas terras do Istmo matou Sínis, o homem que dobrava pinheiros, ${ }^{24}$ da mesma maneira por que ele havia matado muitos viajantes. E fê-lo sem qualquer espécie de treino ou de hábito, antes demonstrando que a coragem é superior a toda a espécie de técnica ou de exercício. Ora Sínis tinha uma filha muito bela e bastante alta, de nome Periguna. 4. Uma vez que ela havia fugido após a morte do pai, Teseu pôs-se à sua procura. Ora a jovem, que se tinha ido refugiar num matagal repleto de arbustos espinhosos e de espargos bravios, com uma candura pueril se lhes dirigia, como se as plantas a pudessem compreender, e lhes prometia e jurava que, caso a salvassem e a escondessem, jamais as arrancaria ou lhes deitaria fogo. 5. Teseu chamou-a e garantiu-lhe que a trataria bem e que nunca lhe causaria dano. Ela saiu então de onde se encontrava e da sua uniáo com Teseu nasceu Melanipo. Posteriormente desposou Deioneu, filho de Eurito da Ecália, a quem Teseu a havia conce-

${ }^{24}$ Gr. Pityokamptes. O epíteto está relacionado com o método de tortura aplicado aos viandantes. Segundo a maioria das fontes antigas, este malfeitor (que Baquílides e Higino dão como filho de Poséidon) ataria os membros das vítimas a dois pinheiros que dobrava, para depois soltar, provocando, assim, o desmembramento e morte delas; segundo outros, as vítimas seria projectadas do topo de um pinheiro dobrado até ao chão, depois de o desprender. 
dido. 6. De Melanipo, filho de Teseu, nasceu Ioxo que, juntamente com Ornito, veio a fundar uma colónia na Cária. Foi desse gesto ancestral que os descendentes de Ioxo, homens e mulheres, herdaram o costume de náo queimar os arbustos com espinhos e os espargos bravios, mas antes de os venerarem e respeitarem. ${ }^{25}$

9. 1. Quanto à javalina de Crómion, conhecida por Féa, ${ }^{26}$ não se tratava de um animal comum, mas antes de um espécime agressivo e difícil de dominar. 2. Foi à margem do seu caminho que Teseu a enfrentou e a matou, para que não parecesse que só agia em caso de necessidade própria. Era convicção sua que aos malfeitores devia um homem valoroso fazer frente em defesa própria, mas que em relação às feras devia tomar a iniciativa de as atacar, mesmo correndo risco de vida. Há quem diga que Féa era uma mulher dada ao latrocínio, sanguinária e sem escrúpulos, que habitava ali, em Crómion, que era apodada de javalina pelo seu carácter e modo de vida e que foi morta às mãos de Teseu. ${ }^{27}$

25 Para além da dimensão etiológica em relação aos costumes dos descendentes de Ioxo, este episódio reveste-se de um dimensão expressiva grande, como nota, com toda a razáo, AMPOLO (1993) comm. ad. 8. 6. Pela primeira vez se assinala uma tendência na $p h y-$ sis de Teseu que interferirá com a sua filantropia e magnanimidade: o impulso erótico que o leva ao estupro, aqui brandamente insinuado.

${ }^{26} \mathrm{O}$ nome é indicador da cor escura e pardacenta do animal. Segundo Apolodoro, teria nascido de Equidna e Tifăo.

27 Referência a Filócoro, segundo PÉREZ JIMÉNEZ (1985) 165 n.40. A menção desta alternativa atesta a simpatia de Plutarco pela racionalizaçáo do mito. Filócoro foi um político e historiógrafo ateniense, de pendor racionalizante. Viveu no séc. IV a. C. 
10. 1. Quanto a Escíron, ${ }^{28}$ Teseu matou-o quase ao entrar na regiáo de Mégara, despenhando-o de uns rochedos. Este bandido, segundo a versão corrente, assaltava os viandantes. Há quem apresente também outra versão: que ele, num gesto de insolência e arrogância, apresentava os seus pés aos estrangeiros e obrigava-os a lavar-lhos. Então, enquanto estes lhos lavavam, aplicava-lhes um pontapé com que os atirava ao mar. 2. No entanto, os historiógrafos provenientes de Mégara encaminham-se no sentido contrário ao desta versão e, como diz Simónides:

Fazem guerra a tradições antigas.

Eles afirmam que Escíron não era nem um criminoso nem um salteador, mas que, pelo contrário, perseguia os salteadores e era parente e amigo de homens nobres e justos. 3. É que Éaco era o mais piedoso dos Gregos, ${ }^{29}$ dizem eles, Cicreu de Salamina ${ }^{30}$ recebe,

e desempenhou vários cargos públicos em Atenas. Compôs uma Ática em 17 livros, de que nos chegaram fragmentos. E o mais reconhecido atidógrafo.

${ }^{28}$ A identificação desta figura é problemática e contraditória, consoante o próprio Plutarco o reconhece. Ele combina aqui, muito provavelmente, duas versóes diversas do mito: a mais comum e a megarense.

${ }^{29}$ Éaco era filho de Zeus e de Egina. Foi o fundador da família dos Eácidas. Estes governaram também Salamina (Ájax é seu descendente) e na Tessália.

${ }^{30}$ Cicreu era um herói de Salamina, filho de Poséidon e Salamina. 
em Atenas, honras divinas e a virtude de Peleu e de Télamon não há quem a desconheça. Ora Escíron era genro de Cicreu, sogro de Éaco, avô de Peleu e de Télamon, nascido de Endeide, filha de Escíron e de Cariclo. 4. Não é, assim, verosímil que os mais nobres de entre os homens estabeleçam alianças de sangue com um indivíduo de todo depravado e que desse homem recebam e a ele lhe concedam o que há de mais importante e valioso. Asseveram ainda que não foi na sua primeira viagem para Atenas que Teseu matou Escíron, mas mais tarde, quando tomou Elêusis, então em poder dos Megarenses, depois de ter afastado Diocles, que aí tinha o seu comando. Esta história apresenta, por conseguinte, controvérsias desta índole.

11. 1. Em Elêusis Teseu saiu vencedor da luta com Cércion da Arcádia ${ }^{31}$ e matou-o. Em seguida avançou um pouco mais, até Erineu, e aí matou Damastes, conhecido por Procustes, forçando-o a moldar-se à dimensão dos seus leitos, conforme este o fazia com os estrangeiros. ${ }^{32} \mathrm{E}$ com este seu modo de agir ia imitando Héracles. 2. É que também Héracles se defendia de

${ }^{31} \mathrm{O}$ combate entre Teseu e Cércion era visto como um primeiro exemplo de luta. Esta figura é dada, em algumas versóes mitológicas, como filho de Poséidon.

${ }^{32}$ A tradição conta que este malfeitor possuía dois leitos - um grande e outro pequeno - e forçava as suas vítimas a deitar-se neles: as altas no pequeno, as baixas no grande. De seguida, torturava-as, mutilando as primeiras até ficarem reduzidas ao tamanho do leito e golpeando as baixas até os seu corpos preencherem o comprimento do leito que eram forçadas a ocupar.. O nome Procustes está, precisamente, relacionado com o acto de golpear (gr. prokouo). 
quem o atacava recorrendo às mesmas técnicas que o agressor usava: foi assim que sacrificou Busíris, ${ }^{33}$ venceu Anteu, ${ }^{34}$ derrotou $\mathrm{Cicno}^{35}$ em combate singular, e matou Térmero, ${ }^{36}$ aplicando-lhe na testa um golpe de cabeça. 3. É daí, segundo se diz, que provém a expressão "dor terméria" pois, ao que parece, Térmero matava quem se lhe deparasse com um tal golpe de cabeça. Deste modo Teseu perseguia e atacava os celerados, submetendo-os ao mesmo tipo de violências que eles infligiam às suas vítimas. Assim eles eram alvo de justiça através dos processos pelos quais haviam praticado a injustiça.

12. 1. Prosseguindo o seu caminho, Teseu chegou às margens do Cefiso. ${ }^{37}$ Aí chegaram ao seu encontro homens da casa dos Fitálidas, que foram os primeiros a vir saudá-lo. Teseu pediu-lhes que o purificassem e eles agiram segundo o ritual preceituado. ${ }^{38} \mathrm{E}$ então, depois

${ }^{33}$ Busíris, rei do Egipto, sacrificava os seus hóspedes.

${ }^{34} \mathrm{O}$ gigante Anteu era filho de Poséidon e Gaia ( a Terra). Matava todos os viandantes que encontrava no seu caminho. Sua máe havia-lhe dado o dom de, sempre que tocasse a terra, recuperar forças.

${ }^{35}$ Cicno era filho de Ares e de Pelópia. Roubava todas as hecatombes que se destinavam ao santuário de Apolo, em Delfos.

${ }^{36}$ Seria um pirata, epónimo de Terméria, na península de Halicarnasso.

${ }^{37}$ Vários rios tiveram, na Grécia, este nome. Aqui trata-se do rio que passava perto de Elêusis.

${ }^{38}$ Segundo Pausânias, 1.37.4, por ter morto Sínis, filho de Poséidon, que seria, por isso, aparentemente seu irmão, tendo em conta a versão posta a correr em Trezena sobre a filiação de Teseu. Pausânias refere este episódio como aition de um altar a Zeus Meilichios, existente entre Atenas e Elêusis. Vide AMPOLO (1993) 212. 
de terem feito um sacrifício propiciatório, receberam-no em sua casa. Até àquele momento ele não tinha encontrado no seu caminho ninguém com sentimentos humanitários. 2. Foi no dia oito do mês de Crónios, hoje também designado por Hecatombéon, ${ }^{39}$ que se conta que Teseu chegou à cidade. À sua chegada deparou-se com uma situação geral de agitação e discórdia e até os interesses privados de Egeu e de sua casa se encontravam ameaçados. 3. Medeia, depois de ter fugido de Corinto, com a promessa de curar Egeu da sua esterilidade por meio de fármacos, vivia com ele. ${ }^{40}$ Entáo, pressentindo quem era Teseu, enquanto Egeu o ignorava ainda, ela persuadiu o rei, que vivia completamente possuído pelo receio de discórdia civil, a convidar o estrangeiro para um banquete e a envenená-lo.

4. Teseu apresentou-se então no banquete, mas não achou oportuno revelar à partida a sua identidade, pois pretendia proporcionar a Egeu um motivo para o reconhecimento. Serviram-se as carnes. Então aquele, sacando da espada, como quem as vai trinchar, exibiu-a perante o rei. 5. Depressa se fez luz no espírito de Egeu, que derrubou a taça de veneno e que, depois de fazer várias perguntas a seu filho, o abraçou. Reunindo de seguida os cidadáos, deu-o a conhecer - e eles acolheram-no com agrado pela coragem que mostrou. 6. Diz-se que a

39 Primeiro mês do calendário ático. Corresponde à segunda quinzena de Julho e à primeira de Agosto.

${ }^{40}$ Heródoto 7. 62 conhece já uma versão mitológica da presença de Medeia em Atenas. É possível que a sua relação com a promessa de cura da esterilidade de Egeu decorra de Eurípides, $\mathrm{Me-}$ deia, vv. 663 ss. 
taça, ao cair, derramou o veneno no sítio onde hoje é o recinto do Delfínion. ${ }^{41}$ Foi aí, de facto, que Egeu passou a habitar e ao Hermes que se encontra a leste do templo chama-se Hermes das portas de Egeu.

13. 1. Até então os Palântidas nutriam a esperança de vir a ocupar o trono de Egeu, uma vez que este morresse sem descendência. Mas quando Teseu foi indigitado como sucessor, eles, que a custo suportavam o facto de Egeu governar, sendo filho adoptivo de Pandíon, sem qualquer laço de parentesco com os Erectidas e agora de Teseu vir a suceder-lhe como rei - mais uma vez um forasteiro, um estranho - avançaram para a guerra.

2. Dividiram-se em dois grupos. Um grupo, que incluia o pai deles, avançou em campo aberto de Esfeto $^{42}$ até à cidade. Os outros esconderam-se, armando uma emboscada em Gargeto, ${ }^{43}$ para atacar os adversários por dois lados. Entre eles encontrava-se um arauto de Hagnunte, ${ }^{44}$ de nome Leos, ${ }^{45} 3$. Este homem revelou a Teseu os desígnios dos Palântidas. Então Teseu caiu de surpresa sobre os que tinham armado a emboscada e matou-os a todos. Os que estavam com Palante, sabendo do ocorrido, dispersaram-se. 4. Desde então, ao que dizem, náo é permitido aos naturais de Palene desposa-

${ }^{41}$ Templo de Apolo Delfínio, em Atenas.

42 Esfeto era um demo do interior da Ática, ligado à tribo dos Acamântidas e próximo do Himeto.

${ }^{43}$ Gargeto ficava entre o Himeto e o Pentélico.

${ }^{44}$ Tal como Esfeto, Hagnunte pertencia à tribo dos Acamântidas.

${ }^{45} \mathrm{O}$ termo leos significa, em grego, 'povo'. 
rem ninguém de Hagnunte e em Palene os arautos não apregoam, conforme é uso, "escuta, ó povo". É que se nutre nesse lugar aversão por tal palavra, devido ao gesto de traição daquele homem.

14. 1. Movido pelo desejo de realizar feitos e, ao mesmo tempo, de granjear popularidade, Teseu foi em perseguição do touro de Maratona, ${ }^{46}$ que causou grandes prejuízos aos habitantes da Tetrápole. ${ }^{47}$ Dominou-o e exibiu-o, passeando-o vivo pela cidade, para em seguida o sacrificar a Apolo Delfínio.

2. A história de Hécala e os relatos lendários sobre a sua hospitalidade e acolhimento parecem não ser de todo destituídos de verdade. De facto, os demos da vizinhança reuniam-se nas Hecalésias, faziam sacrifícios a Zeus Hecálio e prestavam honra a Hécala, invocando-a com o diminutivo de Hecalina, pelo facto de ela, quando acolheu Teseu, então bastante jovem, o ter saudado como fazem as pessoas de idade e lhe ter expressado afecto com diminutivos dessa ordem. 3. Quando Teseu partiu para o combate ela fez súplicas a Zeus, com a promessa de lhe oferecer sacrifícios no caso de o jovem regressar são e salvo. Mas Hécala morreu antes que ele regressasse. Recebeu então, pela hospitalidade dispensada, a recompensa a que acima aludi, por ordem de Teseu, conforme o relato de Filócoro. ${ }^{48}$

${ }^{46}$ Este episódio estreita o paralelismo entre Héracles, que venceu o touro de Creta, e Teseu.

47 A Tetrápole ('conjunto de quatro cidades') aqui mencionada incluia Maratona, Tricórito, Énoe, Probalinto.

${ }^{48}$ Filócoro Fgr. Hist 328F. 
15. 1. Pouco depois chegaram de Creta, pela terceira vez, os encarregados de levar o tributo. Depois de Andrógeo, segundo se pensava, ter sido morto à traição em terra da Ática, ${ }^{49}$ Minos desencadeou uma guerra que causou muitas desgraças aos seus habitantes e os deuses provocaram a ruína da região - pois sobreveio o flagelo da esterilidade, de doenças inúmeras, da seca dos rios. A divindade ordenou-lhes que se reconciliassem com Minos e que estabelecessem a paz para acalmar a ira divina e pôr fim aos sofrimentos. Então eles enviaram um arauto a pedir a paz e celebraram um tratado, segundo o qual enviariam de nove em nove anos um tributo de sete jovens e sete donzelas. Quanto a estes factos, está de acordo a maioria dos historiadores.

2. Sobre os jovens que eram levados para Creta, a narrativa mais usual na tragédia declara que eram mortos pelo Minotauro, no Labirinto, ${ }^{50}$ ou que aí pereciam, depois de por ele terem vagueado na busca estéril de uma saída. E o Minotauro, como diz o verso de Eurípides, era

um ser híbrido, uma criatura nefasta,

e possuía

de touro e de homem a mescla de uma dupla natureza.

${ }^{49}$ Andrógeo era filho de Minos, rei de Creta, e de Pasífae. Foi assassinado em terras da Ática, após ter vencido nos Jogos Panatenaicos, quando se dirigia a Tebas. Outras versóes dáo-no como morto por acção de Egeu.

50 O Labirinto, obra de Dédalo, foi mandado construir por Minos como prisáo para encerrar o Minotauro, ser monstruoso e híbrido, nascido de Pasífae e do possante touro de Creta, enviado pelo deus Poséidon. 
16. 1. Filócoro conta que os Cretenses não perfilham esta opinião, mas afirmam que o Labirinto era uma prisão que outro aspecto temível não tinha para além da impossibilidade de fuga dos prisioneiros e que Minos organizava uma competiçáo gímnica e concedia como troféu aos vencedores os jovens, retidos até ao momento no Labirinto. Ora o vencedor dos primeiros jogos foi um general seu, com extremo poder junto da sua pessoa, de nome Tauro, homem sem moderação e de carácter rude, que usava de insolência e dureza para com os filhos dos Atenienses. ${ }^{51}$

2. O próprio Aristóteles, na Constituição dos Botienses, ${ }^{52}$ mostra que não acredita que os jovens tivessem sido mortos por Minos, mas que iam envelhecendo em Creta, na qualidade de servos. Outrora, segundo diz, os Cretenses, para cumprir uma promessa antiga, enviaram a Delfos, como oferenda, primogénitos seus. Misturados com estes seguiam também descendentes dos jovens atenienses. Porém, como não tivessem capacidade de encontrar em Delfos o seu próprio sustento, apontaram primeiro rumo a Itália e aí se estabeleceram na Iapígia. De seguida passaram para a Trácia, onde tomaram o nome de Botienses. 3. É por isso que, entre os

${ }^{51}$ Note-se, uma vez mais, a referência a versóes racionalizadas do mito.

${ }^{52}$ Trata-se de um povo da Macedónia que acreditava ser descendente dos cretenses sediados em Iapígia, após terem sido oferecidos ao santuário de Delfos. Para a tradução de Bottiaioi com um termo enquadrado à tradiçáo portuguesa para nomes que indiquem a naturalidade agradeço a sugestão da Prof. Doutora Maria Helena da Rocha Pereira. 
Botienses, quando as jovens fazem um sacrifício, cantam "vamo-nos para Atenas".

Parece, de facto, arriscado atrair o ódio de uma cidade que tem o apanágio da voz da Musa. É que Minos nunca deixa de ser insultado e injuriado nos teatros da Ática. Nem lhe valeu, sequer, o facto de Hesíodo o apodar de "o mais régio dos reis", nem de Homero lhe chamar "companheiro de Zeus". Foram os poetas trágicos quem levou a melhor e do proscénio e da cena sobre ele fizeram cair um enorme descrédito, ao apresentá-lo como um homem duro e violento. ${ }^{53} 4$. E diz-se, no entanto, que Minos foi rei e legislador e Radamanto juiz e guardião das leis que ele estabeleceu.

17. 1. Mas quando chegou o tempo aprazado para enviar o terceiro tributo e os pais que tinham filhos jovens os deviam apresentar para a tiragem à sorte, reergueram-se as recriminaçôes contra Egeu por parte dos cidadãos; eles lamentavam-se e insurgiam-se por ver que Egeu - afinal o responsável por tudo - era o único a não ser afectado pelo castigo. Pelo contrário: depois de ter dado o poder a um filho bastardo, um forasteiro, não se preocupou ao vê-los privados de filhos legítimos e sem descendência.

${ }^{53}$ Consoante nota AMPOLO (1993) comm. ad 16. 3, Plutarco distingue dois modos de apresentar Minos: um positivo, de Homero (Odisseia 19. 179) e Hesíodo (frg. 144 Merkelbach-West), outro negativo, típico dos trágicos. Várias foram as tragédias perdidas em que a personagem Minos fazia parte da acção - ao que se sabe, pelo menos uma de Ésquilo (Cretenses), uma de Sófocles (Dédalo) e duas de Eurípides (Cretenses e Teseu). Segundo este helenista, o passo mostra influência de Pseudo-Platão, Minos, 318d ss. 
2. Estas queixas afligiam Teseu, que entendeu ser justo não se alhear, mas antes tomar parte na sorte dos seus concidadãos, pelo que se foi oferecer espontaneamente, sem esperar pelo sorteio. Aos demais pareceu admirável esta grandeza de espírito e louvaram a sua devoção para com o povo. Egeu, no entanto, depois o tentar demover com pedidos e súplicas, quando percebeu ter encontrado nele uma disposição inflexível e inamovível, passou a tirar, então, à sorte o nome dos outros jovens.

3. Helânico ${ }^{54}$ afirma, no entanto, que a cidade não tirava à sorte os jovens e as donzelas que havia de enviar, mas era o próprio Minos quem vinha escolhê-los e que este escolheu à partida Teseu, com as seguintes condiçóes: os Atenienses deviam fornecer o navio em que os jovens embarcariam com ele, sem levarem consigo qualquer "arma de guerra" e uma vez morto o Minotauro cessaria o tributo. 4. Das vezes anteriores, como não havia qualquer esperança de salvação, enviavam o navio com uma vela negra, como sinal da desgraça evidente. Desta vez, contudo, já que Teseu animou o seu pai e afirmava que venceria sem mais o Minotauro, este deu uma vela branca ao timoneiro, com a ordem de mudar de vela, içando a branca, no regresso, no caso de Teseu se salvar. De contrário, havia de navegar com a vela negra desfraldada, para anunciar a desdita.

${ }^{54}$ Trata-se de um escritor ático do séc. V a. C. , autor de obras historiográficas, mitográficas. Foi autor de uma obra intitulada Ática, em que desenvolvia a história da Ática desde as suas origens míticas até ao fim da Guerra do Peloponeso: vide PÉREZ JIMÈNEZ (1985) 175 n. 65. A referência a Helânico diz respeito a FgrHist $323 \mathrm{aF} 14$. 
5. Simónides, no entanto, refere que a vela dada por Egeu não era branca, mas uma "vela purpúrea, tingida com a flor sucosa do fecundo carvalho" ${ }^{55}$ e que este era o sinal de salvação dos jovens. Governava o navio Féreclo, descendente de Amársias, ao que diz Simónides. 6. Filócoro, pelo contrário, afirma que Teseu recebeu da parte de Esciro de Salamina um piloto de nome Nausítoo e como ajudante de piloto Féax, uma vez que os Atenienses ainda não se dedicavam à navegação naquela altura e que um dos jovens - Menestes - era neto de Esciro por parte da mãe. 7. Confirmam esta versão, segundo Filócoro, os monumentos dos heróis Nausítoo e Féax, mandados construir por Teseu em Faléron, mesmo junto ao de Esciro, e a festa das Cibernésias, ${ }^{56}$ que é celebrada em honra destes, como ele diz.

18. 1. Depois de feito o sorteio, Teseu trouxe do pritaneu os jovens designados e dirigiu-se ao Delfínion, onde ofereceu por eles o ramo de suplicante a Apolo. Era um ramo da oliveira sagrada, enfaixado com lã branca. ${ }^{57}$ 2. Depois de formular as suas preces, fez-se ao mar no sexto dia do mês de Muníquion, ${ }^{58}$ data em que ainda hoje se mandam as donzelas ao Delfínion, para aí fazer súplicas. 3. Diz-se que o deus de Delfos lhe ordenou que fizesse de Afrodite a sua guia e a invocasse como companheira de

55 Simónides, frg. 550a PMG.

56 Lit. "Festa dos pilotos"

57 Era esta a ornamentação típica dos ramos utilizados nos rituais de súplica.

${ }^{58}$ Este era o décimo mês do calendário ático. Correspondia a parte de Abril e de Maio. 
viagem e que, enquanto ele sacrificava uma cabra junto ao mar, esta se converteu, sem mais, num bode. Por isso, a deusa recebeu o epíteto de Epitrágia.

19. 1. Quando Teseu aportou a Creta, segundo a maior parte das narrativas escritas e dos ditos dos poetas, recebeu das mãos de Ariadne, que se havia apaixonado por ele, o novelo e, informado do modo como podia percorrer os meandros do Labirinto, matou o Minotauro e fez-se ao mar, levando consigo Ariadne e os jovens.

2. Ferecides ${ }^{59}$ afirma que Teseu fendeu o casco aos navios de Creta para impedir que o perseguissem. 3. Démon, ${ }^{60}$ por seu turno, assevera que Tauro, o chefe do exército de Minos, perdeu a vida no porto, num combate a bordo, enquanto Teseu levantava âncora.

4. De acordo com o relato de Filócoro, quando Minos organizou as competiçóes, Tauro era visto como o provável vencedor sobre todos os concorrentes e converteu-se, por isso, num alvo de inveja. 5. O seu poder era motivo de ódio por causa do seu carácter e era acusado de ter relaçóes com Pasífae. Por isso mesmo, acedendo ao pedido de Teseu, Minos deu-lhe consentimento para participar no concurso. 6. Ora era costume em Creta as mulheres assistirem às competiçóes, pelo

${ }^{59}$ Ferecides de Atenas viveu em inícios do séc. V. Escreveu umas Histórias em 10 volumes, de que nos chegaram fragmentos. Parece ter sido o primeiro logógrafo a ocupar-se daa lendas áticas, em particular da expedição de Teseu a Creta e da guerra das Amazonas.

${ }^{60}$ Pouco sabemos sobre este autor atidógrafo. Segundo AMPOLO (1993) comm. ad 10. 3, seria seguramente ateniense e contemporâneo de Filócoro. 
que Ariadne, que estava presente, ficou impressionada à vista de Teseu, e se deslumbrou com a sua vitória. 7 . Minos encheu-se de contentamento, sobretudo por ver a derrota e o ultraje de Tauro, entregou os jovens a Teseu e libertou Atenas do tributo.

8. Singular e extraordinário é o relato de Clidemo ${ }^{61}$ sobre estes factos, remontando a uma época mais recuada. Diz que havia uma lei, comum a todos os Gregos, que proibia que uma trirreme levantasse ferro com mais de cinco homens a bordo. Só Jasão, o comandante da nau Argos navegou sem olhar a esta lei, pois libertava o mar de piratas. Quando Dédalo fugiu para Atenas por mar, ${ }^{62}$ Minos, infringindo aquelas disposiçóes, perseguiu-o com os seus navios, mas uma tempestade arrastou-o para a Sicília e aí perdeu a vida. 9. Quando seu filho, Deucaliáo, que nutria sentimentos hostis contra os Atenienses, lhes fez chegar ordem para entregarem Dédalo à sua autoridade, com a ameaça que, de contrário, mataria os jovens que Minos havia tomado como reféns, Teseu respondeu-lhe com doçura. Solicitou-lhe que deixasse ficar Dédalo, seu primo e parente, porquanto era filho de Mérope, que tinha por pai Erecteu. Mas, entretanto, ele mesmo se aplicou na construção de uma armada, uma parte em Timétadas, ${ }^{63}$ longe dos caminhos frequentados por forasteiros, uma parte

${ }^{61}$ Clidemo foi um atidógrafo que viveu no séc. IV a. C., de tendência racionalizante quanto ao mito.

${ }^{62}$ Esta não é a versão mais corrente do mito de Dédalo, senão a que narra como ele e seu filho Ícaro modelaram asas de cera para escapar do Labirinto, voando.

${ }^{63}$ Demo ático da tribo Hipotoôntida. Situava-se a norte do Pireu. 
em Trezena, por intermédio de Piteu, com o objectivo de manter secreto o empreendimento.

10. Quando tudo ficou pronto, fez-se ao mar, levando consigo Dédalo e exilados cretenses para lhe servirem de guias. Ninguém suspeitou de nada. Pelo contrário: os Cretenses pensavam que eram navios amigos que se aproximavam. Assim ocupou o porto, desembarcou e depressa chegou a Cnossos, antes da notícia. Travou uma luta às portas do Labirinto em que matou Deucaliáo e os seus lanceiros. Tendo entáo Ariadne subido ao poder, estabelece com ela um tratado, recupera os jovens reféns e cria laços de amizade entre Atenienses e Cretenses, com o juramento de que não voltariam a entrar em guerra.

20. 1. Muitas são as histórias que se contam sobre estes acontecimentos e sobre Ariadne e que não se coadunam entre si. Numas se afirma que Ariadne se enforcou, uma vez abandonada por Teseu; noutras ${ }^{64}$ que foi levada pelos marinheiros até Naxos e aí desposou Enaro, ${ }^{65}$ sacerdote de Dioniso, e que Teseu a abandonara por se haver enamorado de outra mulher. ${ }^{66}$

${ }^{64}$ PÉREZ JIMÉNEZ (1985) 179 n. 77, aponta Diodoro como fonte.

${ }^{65}$ Nota FLACELIÈRE-CHAMBRY (1957) 28 n. 1, que o nome do sacerdote (gr. Oinaros), tal como o de Enópion (gr. Oinopion), está relacionado com o vinho (gr. oinos). Estáfilo, por sua vez, está relacionado com as uvas (o cacho de uvas maduro é designado em grego por staphyle).

${ }^{66}$ A ligação entre Ariadne e Dioniso, bem como a intervençáo de Teseu na sua saída de Creta, são já referidas na Odisseia, 11. 321-325. Aí, diz o poeta, Ariadne teria sido morta por Ártemis, em Naxos, por testemunho de Dioniso, aquando da viagem de Teseu, 
Pois consumia-o uma paixão por Egla, filha de Panopeu.

2. Este verso,${ }^{67}$ diz Héreas de Mégara, ${ }^{68}$ suprimiu-o Pisístrato dos poemas de Hesíodo, enquanto que, ao invés, interpolou este outro na Nekyia de Homero, para ajudar os Atenienses:

Teseu e Pirítoo, ilustres filhos dos deuses.

Há quem diga que Ariadne concebeu de Teseu Enópion e Estáfilo. Um dos que o afirmam é Ílon de Quios, ao falar da sua própria pátria: ${ }^{69}$

Fundada então por Enópion, filho de Teseu.

3. Estas são as versões mais conhecidas da lenda que, por assim dizer, circulam de boca em boca. Mas sobre estes episódios foi dada uma singular versão por Péon de Amatunte. ${ }^{70}$ 4. Refere ele que Teseu foi arrastado até Chipre por uma tempestade e que Ariadne estava grávida. Como ela se sentia mal, por causa da agitação do

que a levava consigo para Atenas.

${ }^{67}$ Hesíodo, frg. 298 Merkelbach-West.

68 Trata-se de um historógrafo natural de Mégara que, ao que parece, apenas Plutarco referencia. Teria vivido no séc. IV a. C..

${ }^{69}$ Trata-se de um poeta lírico, também autor de tragédias, filósofo e autor de obra historiográfica em prosa, natural da ilha de Quios, que viveu no séc. V a. C. Foi amigo de Címon, o político que "valorizou" politicamente o mito de Teseu. Íon tentaria, assim, sancionar através das relaçóes de descendência, no mito, a proximidade política entre Atenas e Quios.

${ }^{70}$ Este historiógrafo viveu no séc. III a. C. e era natural de Chipre, onde ficava a sua cidade natal. 
mar, e se encontrava esgotada, fê-la desembarcar sozinha. Quanto a ele, ao regressar ao navio, com o fim de o salvar, foi de novo arrastado para o alto mar. 5. Então, as mulheres daquele lugar acolheram Ariadne e rodearamna de cuidados, no sofrimento da sua solidão. Levavamlhe até cartas forjadas, como se Teseu lhas tivesse escrito. Chegada a hora do parto, acompanharam-na nas suas dores e assistiram-na; mas, uma vez que morreu sem ter conseguido dar à luz, deram-lhe sepultura. 6. Quando Teseu regressou, arrebatado por um profundo desgosto, deixou as suas riquezas às gentes daquela terra, com o compromisso de instituírem sacrifícios em memória de Ariadne e de lhe erguerem duas pequenas estatuetas, uma de prata, outra de bronze. 7. E durante o sacrifício, que tem lugar no segundo dia do mês de Gorpieu, ${ }^{71}$ um jovem, deitado sobre um leito, imita os gritos e os gestos das mulheres que estáo a dar à luz. Os habitantes de Amatunte dáo ao bosque sagrado em que mostram o túmulo o nome de bosque de Ariadne-Afrodite. 8. E há até alguns escritores de Naxos que contam uma versão singular: que existiam dois Minos e duas Ariadnes: uma, segundo afirmam, desposou Dioniso, em Naxos, e deu à luz Estáfilo e seu irmão, enquanto que a outra, mais recente, foi raptada e abandonada por Teseu, chegou a Naxos, na companhia da sua ama, de nome Córcina, da qual se mostra aí o túmulo. 9. Esta segunda Ariadne também morreu na ilha e recebe honras diferentes das prestadas à primeira, pois a homenagem prestada à

${ }^{71}$ Mês do calendário macedónio, que compreende parte de Agosto e de Setembro. 
primeira das duas Ariadnes festeja-se com alegria e divertimentos, enquanto que os sacrifícios oferecidos em memória da segunda vão associados à dor e à tristeza.

21. 1. Deixando Creta, Teseu rumou até Delos. Aí, depois de oferecer sacrifícios ao deus e lhe dedicar a estátua de Afrodite que Ariadne lhe havia oferecido, executou com os jovens uma dança que, ao que se diz, os habitantes de Delos ainda hoje praticam. Ela imita, pelas suas figuras, as voltas e reviravoltas do Labirinto, num ritmo marcado por movimentos circulares alternados. $^{72}$ 2. Este tipo de dança é conhecido, entre os Délios, pelo nome de "grua", como atesta Dicearco. ${ }^{73} \mathrm{Te}-$ seu executou-a à volta do Quératon, altar formado por cornos de toda a espécie, provenientes do lado esquerdo da cabeça dos animais. ${ }^{74} 3$. Diz-se que também instituiu jogos, em Delos, e que aos vencedores da primeira competição lhes atribuiu um ramo de palmeira.

72 Delos, como ilha natal de Apolo e Ártemis, era tida como território sagrado do deus. A passagem de Teseu pela ilha ficou miticamente marcada pela instituição de ritos e de gestos religiosos: a oferta da pequena imagem de Afrodite, a dança ritual, a instituição de jogos em honra do deus. A versão da presença de Teseu em Delos prestava-se, no séc. V a. C., a várias explicaçóes etiológicas. A estatueta de Afrodite (gr. xoanon) encontrar-se-ia no Afrodísion. Pausânias descreve-a (9. 40. 3-4).

${ }^{73}$ Trata-se de um filósofo peripatético, discípulo de Aristóteles. Nasceu na Sicília e viveu entre meados do séc. IV e o primeiro quartel do séc. III a. C. Escreveu também algumas biografias. Os Romanos apreciavam a sua sólida cultura e erudição.

${ }^{74}$ Este altar era tido como uma das maravilhas do Mundo Antigo. (cf. Plutarco, Mor. 983E). 
22. 1. Quando já se encontravam perto da Ática, devido ao júbilo que os possuía, Teseu esqueceu-se, e o seu piloto igualmente se esqueceu, de içar a vela que deveria assinalar a Egeu que regressavam incólumes. Egeu, num acto de desespero, atirou-se do cimo de um rochedo e pôs assim termo à vida. ${ }^{75} 2$. Uma vez desembarcado, Teseu celebrou pessoalmente, em Falero, os sacrifícios que tinha prometido aos deuses no momento em que levantara âncora. ${ }^{76}$ Enviou, entretanto, um arauto à cidade, com a notícia de que tinham chegado a salvo. Este arauto encontrou, pelo caminho, muitas pessoas que choravam a morte do rei e outras que, cheias de alegria, como é natural, se mostravam desejosas de manifestar a sua simpatia e de o coroar pela notícia do feliz regresso. 3. E ele recebeu as coroas, com que cobriu o seu caduceu. De volta em direcção ao mar, uma vez que Teseu não tinha ainda concluído as suas libaçóes, mantevese à parte, para não perturbar a cerimónia. Concluída esta, anunciou a morte de Egeu. 4. E foi por entre gritos e gemidos que todos tomaram, à pressa, o caminho para a cidade. Daí provém o costume, diz-se, que ainda hoje se mantém, de não coroar o arauto, mas sim o seu caduceu, na festa das Oscofórias e de, no momento da libação, os participantes gritarem "eleleu", ioú, ioú". O primeiro grito é o que se costuma lançar ao fazer libaçóes e entoar um péan, enquanto que o segundo assinala a dor e a agitação.

75 Nota PÉREZ JIMÉNEZ (1985) 182 n.88, que esta versão representa o esforço comum dos mitógrafos para procurar um motivo para o parricídio involuntário de Teseu.

${ }^{76}$ Trata-se do referido em 17.7, incluindo a festa das Cibernésias. 
Depois de ter dado sepultura a seu pai, Teseu cumpriu os votos feitos a Apolo, no dia sete do mês de Pianépsion, pois foi nesse dia que entraram na cidade sãos e salvos. ${ }^{77}$ 5. Diz-se que o hábito de cozer legumes nesse dia vem do facto de os jovens salvos por Teseu terem juntado o que restava dos seus víveres e, depois de terem cozido tudo numa panela comum, partilharam a refeição que comeram em conjunto. 6. Carregam a eiresione, que é um ramo de oliveira enfaixado com lâ, ${ }^{78}$ tal como o ramo de suplicante da cerimónia anterior à partida, mas agora enfeitado com toda a espécie de frutos, pelo facto de ter cessado o flagelo da esterilidade, e vão cantando:

\section{Eiresione, leva figos e belos pães}

e um potezinho de mel e azeite para te ungires, e um cálice de vinho puro, para caíres no sono ébria.

Há, contudo, quem afirme que este ritual surgiu em função dos Heraclidas, que assim foram alimentados pelos Atenienses; a maioria, no entanto, segue a versão aqui exposta.

23. 1. O navio em que Teseu fez a travessia com os jovens e em que regressou são e salvo era uma

${ }^{77} \mathrm{O}$ mês recebe o nome destas mesmas celebraçóes, as Pianépsias, em honra de Apolo. O nome da festa está relacionado com o hábito de nelas se comer cereais e legumes cozidos, sobretudo favas (gr. pyanos).

${ }_{78}$ Gr. eiros. O termo eiresione está relacionado com a palavra 'lâ' e é intraduzível. 
embarcação de trinta remos que os Atenienses conservaram até ao tempo de Demétrio de Falero. ${ }^{79}$ Retiravam o madeiramento envelhecido e substituíam-no por pranchas robustas, que ajustavam às outras, de tal modo que, para os filósofos, este navio representava um exemplo adequado à discussão sobre o "argumento do crescimento", defendendo uns que o navio continuava a ser o mesmo e outros que já o não era.

2. A festa das Oscofórias, ${ }^{80}$ que ainda hoje se celebra, foi instituída por Teseu. 3. É que ele não levou todas as jovens tocadas pelo sorteio, mas substituiu duas por jovens seus companheiros, de aparência feminina e delicada, mas de ânimo viril e corajoso. Com banhos quentes, uma vida à sombra, unguentos e adornos sobre o cabelo e a pele macia, Teseu transformou-os na medida do possível, ensinando-lhes também a falar, a estar e a caminhar de modo a assemelharem-se o mais possível a raparigas e em nada se diferenciarem delas. Em seguida, integrou-os no grupo das jovens e ninguém deu por nada.

No seu regresso, Teseu abriu o cortejo com os ditos jovens, vestidos como ainda hoje se vestem aqueles que transportam os ramos. 4. Levam-nos para agradecer a Dioniso e Ariadne, pela parte que lhes toca na história, ou antes, por terem regressado no tempo das colheitas. As mulheres encarregadas de levar a comida associam-se à festa e participam nos sacrifícios, imitando as mães

${ }^{79}$ Filósofo peripatético que governou em Atenas entre 317 e 307 a. C.

${ }^{80} \mathrm{O}$ seu nome indica 'que se transporta uma haste nova'. 
daqueles jovens a quem tocaram as sortes (estas, de facto, iam e vinha para lhes trazer o pão) e contam histórias, pois também as mães dos jovens as contavam aos seus filhos, para lhes darem ânimo e os confortarem. 5. Estas informaçóes também Démon as registou. Consagrou-se a Teseu um recinto e ele determinou que os membros daquelas famílias que tinham participado no tributo deviam entrar no pagamento das despesas com os sacrifícios em sua honra. Confiou à guarda dos Fitálidas a responsabilidade pela cerimónia, num gesto de gratidão pela hospitalidade que deles havia recebido. ${ }^{81}$

24. 1. Após a morte de Egeu, concebeu um magnífico e admirável projecto: congregou os habitantes da Ática numa só cidade e declarou um único estado, correspondente a um só povo. Até então a população vivia dispersa pelo território e era difícil reuni-la em função do bem comum a todos os seus elementos. Acontecia mesmo entrarem em dissensóes e guerras entre eles. 2. Assim, Teseu foi ter com eles pessoalmente e foi persuadindo comunidade a comunidade, família a família, a fim de a todos conquistar para este seu projecto. Os homens comuns e os pobres depressa acolheram o seu apelo. Aos poderosos propunha-lhes um sistema de governo sem rei e uma democracia que viesse a recorrer à sua própria pessoa apenas como chefe militar e guardiáo das leis, e que em tudo o resto proporcionasse a todos igualdade de direitos. ${ }^{82}$ Uns deixaram-se persuadir; outros, com receio

${ }^{81}$ Vide supra 12. 1.

${ }^{82} \mathrm{Gr}$ isomoiria. 
do seu poder, que já era grande, e da sua audácia, entenderam ser preferível anuir a ter de ceder pela força.

3. Teseu mandou então deitar abaixo os pritaneus e as salas de conselho locais, aboliu as magistraturas de cada comunidade e ergueu um pritaneu e uma sala de conselho comum a todos no lugar onde hoje se ergue a cidade. Deu a este Estado o nome de Atenas e instituiu as Panateneias como festa da comunidade. ${ }^{83}$ 4. Instituiu também as Metéquias no dia dezasseis do mês de Hecatombéon, que ainda agora se celebram.$^{84} \mathrm{E}$ depois de abdicar do trono, conforme havia acordado, regulamentou o governo do Estado, começando por ouvir os deuses. Consultado o oráculo de Delfos a propósito de Atenas, recebeu a seguinte resposta:

5. Égida Teseu, nascido da filha de Piteu, de muitas cidades colocou meu pai os limites e o destino na vossa cidade, mas náo canses demasiado o teu espírito em meditaçôes, pois hás-de atravessar o mar como um odre sobre as ondas.

${ }^{83}$ As Panateneias eram celebradas em honra da deusa protectora da pólis - Atena, de que levam o nome (lit. 'festa de conjunta em honra de Atena'). Realizavam-se no dia 28 do mês de Hecatombéon (o primeiro mês do calendário ático, correspondente a parte de Julho e de Agosto), dia do aniversário da deusa. As Grandes Panateneias, instituídas pelos Pisístratos, celebravam-se de quatro em quatro anos e duravam quatro dias.

${ }^{84}$ É possível que Plutarco haja confundido a designação. Tucídides fala não de Metoikia mas de Synoikia (2. 14.2). Também é possível que o nome tenha sido alterado, já que o sinecismo obrigou primeiro a uma migração interna e a nova instalação dos atenienses (o que justificaria a primeira designaçáo). 
6. Conta-se que mais tarde a Sibila aplicou este vaticínio à cidade:

Que o odre mergulhe, mas não é seu destino afundar-se.

25. 1. Com o propósito de expandir ainda mais a cidade, mandava chamar toda a gente com a promessa de igualdade de direitos. Dizem que a proclamação dos arautos - "acorrei todos aqui, ó gentes" - teve origem em Teseu, quando este se esforçava por fundir todos os povos numa comunidade.

2. Ele não permitiu, no entanto, que a democracia se convertesse em desordem e confusão graças a uma multidão desordenada que invadisse a cidade. Pelo contrário - começou por dividir os cidadáos em Eupátridas, Geómoros e Demiurgos. Aos Eupátridas atribuiu a função de conhecer os assuntos relativos aos deuses, de proporcionar magistrados, de ensinar as leis, de interpretar o profano e o sagrado. Estabeleceu uma espécie de igualdade com as outras duas classes de cidadáos. Os Eupátridas pareciam preponderar em dignidade, os Geómoros em utilidade, os Demiurgos em número.

3. Que Teseu foi o primeiro a inclinar-se para o poder da multidão, conforme Aristóteles afirma, e que renunciou à monarquia, parece testemunhá-lo Homero, no "Catálogo das Naus", ${ }^{85}$ quando designou somente os Atenienses por povo. Mandou também cunhar moeda com a efígie de um boi gravada, em alusão ao touro de Maratona, ou ao comandante militar de Minos, ou

${ }^{85}$ Iliada, 2. 547. 
ainda para incitar os cidadãos à actividade agrícola. Dizse que daqui deriva a expressáo "no valor de cem bois" ou "no valor de dez bois".

4. Depois de alargar decisivamente a Ática com a firme anexação de Mégara, mandou erigir no Istmo a famosa estela ${ }^{86}$ cuja inscrição, em dois trímetros, delimitava a fronteira. A face virada a este dizia:

Aqui já não é Peloponeso, é a Iónia.

Na parte virada a oeste lia-se:

Aqui é Peloponeso, já não é a Iónia.

5. Foi também o primeiro a instituir jogos, rivalizando com o papel de Héracles, com o desejo de que, assim como se celebravam os Jogos Olímpicos em honra de Zeus, graças a Héracles, celebrassem os Gregos, por sua iniciativa, os Jogos Ístmicos, em honra de Poséidon.

De facto, o concurso instituído em memória de Melicertes ${ }^{87}$ decorria de noite, tendo assim mais o as-

${ }^{86}$ Esta estela era mencionada pelos atidógrafos, sobretudo Filócoro. Lembra AMPOLO (1993) comm. ad 26. 4, que Pausânas 1. 42. 1, reportando-se a uma fonte antimegarense, procurou demonstrar que Mégara, desde a origem, era tributária de Atenas.

${ }^{87}$ Neto de Cadmo e filho de Ino. Esta, fugindo à fúria de Atamante, seu marido, precipitou-se no mar com seu filho Melicertes. Ambos foram metamorfoseados em divindades marinhas - aquela com o nome de Leucoteia, este com o de Palémon. Eurípides, Medeia, v. 1284 ss recorre a outra versão: Ino, enlouquecida, matou os seus dois filhos e lançou-se ao mar. 
pecto de um mistério que de um espectáculo e de uma festa pública. ${ }^{88}$

6. Há quem diga que os Jogos Ístmicos foram instituídos em memória de Escíron, uma vez que Teseu pretendia expiar a sua morte, dados os laços de parentesco. É que Escíron, diziam, era filho de Caneto e Heníoque, filha de Piteu. Mas outros referem Sínis e não Escíron e que foi em honra do primeiro e não do segundo que os jogos foram instituídos por Teseu.

7. Este fixou e estipulou com os Coríntios que os Atenienses que viessem para assistir aos jogos teriam direito a um espaço, na primeira bancada, correspondente ao que pudesse ser coberto pela vela desfraldada do navio que transportava os teoros. ${ }^{89}$ Assim o atestam Helânico e Ândron de Halicarnasso. ${ }^{90}$

26. 1. Teseu fez-se ao mar rumo ao Ponto Euxino, segundo afirmam Filócoro e outros, com o fim de combater ao lado de Héracles contra as Amazonas. E como recompensa pela sua bravura foi-lhe dada Antíope. Mas

${ }^{88}$ Este Jogos eram os mais importantes depois dos Olímpicos. Realizavam-se em Corinto, em Abril, a partir de 581 a. C. no segundo e no quarto ano de cada Olimpíada, em honra de Poséidon. Plutarco combina, aqui, as duas tradiçóes sobre a sua origem - a que os dá como fundados em honra de Melicertes (a partir de jogos fúnebres) e a que os dá como instituídos por Teseu. Esta última atesta o paralelismo de iniciativas entre Teseu e Héracles. Náo se sabe, exactamente, que tipo de provas aí decorrriam. Sabe-se que os atletas vencedores eram, inicialmente, contemplados com uma corao de aipo seco e, mais tarde, de ramos de pinheiro.

${ }^{89}$ Espectadores enviados oficialmente pelas póleis gregas para assistirem a jogos públicos pan-helénicos.

${ }^{90}$ Autor do séc. IV a. C. Escreveu os Syngenika, que se ocupavam das relaçóes genealógicas entre cidades e etnias gregas. 
a maior parte dos historiadores, entre os quais se contam Ferecides, Helânico e Herodoro, ${ }^{11}$ defendem que Teseu partiu depois de Héracles, com a sua própria armada, e que tomou a Amazona como prisioneira de guerra. Esta versão é mais convicente. ${ }^{92} 2$. Com efeito, não há relatos de que algum outro dos que o acompanhavam na expedição tivesse capturado uma Amazona. Bíon ${ }^{93}$ refere que ele a aprisionou recorrendo a um ardil, já que as Amazonas, por serem de sua natureza apreciadoras dos homens, não fugiram de Teseu quando ele entrou no seu território, mas enviaram-lhe até presentes de hospitalidade. Entáo Teseu convidou a Amazona que lhos vinha entregar a subir ao seu navio e, uma vez que a apanhou a bordo, fez-se ao largo.

${ }^{91}$ Herodoro de Heracleia escreveu, por volta de 400 a. C., monografias sobre figura mitológicas que conheceram grande divulgação. Tornou-se uma autoridade para comentadores posteriores, juntamente com Ferecides e Helânico.

${ }^{92}$ De facto, existiam dois filóes de tradição sobre a guerra das Amazonas: o que autonomiza o empreendimento de Teseu, e que parece ser mais antigo, e o que o associa a Héracles, dentro da tendência de associação dos dois heróis. Esta tendência pode ter nascido no tempo dos Pisístratos e ter sido reforçada pela Teseida. $\mathrm{O}$ próprio nome da Amazona que anda associada a Teseu varia: a tradição mais antiga parece ser a que fala de Hipólita e que é bem conhecida através de Eurípides, Hipólito. Fala por ela o facto de nome do filho de Teseu decorrer do da mãe. Outra tradição (Filócoro FgrHist 328F 110) dá-lhe o nome de Antíope. Conhece ainda outros nomes, em tradição tardia: vide PÉREZ JIMÉNEZ (1985) 188 n. 100.

${ }^{93}$ Bíon de Proconeso, figura cuja identidade é pouco conhecida bem como, em rigor, o seu papel (atribui-se-lhe a compilação da obra de Cadmo de Mileto, outra figura problemática, cujos escritos seriam anteriores a Heródoto). 
3. No entanto, um tal Menécrates, ${ }^{94}$ que publicou uma história da cidade de Niceia, na Bitínia, afirma que Teseu, já na posse de Antíope, permaneceu algum tempo nessas paragens. Com ele tomaram parte na expedição três jovens atenienses que eram irmãos: Êuneo, Toante e Soloente. 4. Ora este último apaixonou-se por Antíope, o que ocultou de todos os companheiros, tendo-o apenas confessado a um que, ao encontrar Antíope, lhe falou do caso. Ela repeliu decididamente a tentativa de sedução; conduziu, contudo, o assunto com prudência e suavidade e não o denunciou a Teseu.

5. Mas Soloente, por desespero, atirou-se a um rio e morreu. Teseu apercebendo-se então dos motivos da morte e da paixão do jovem, ficou profundamente abalado e, no seu desgosto, recordou-se dum oráculo da Pitonisa. De facto, havia-lhe sido ordenado pela Pitonisa, em Delfos, que, quando sofresse um enorme desgosto em terra estrangeira e estivesse particularmente deprimido, aí fundasse uma cidade e nela deixasse como governantes alguns companheiros seus. 6. Por tal motivo deu o nome de Pitópolis, em honra do deus, à cidade que fundou e de Soloente ao rio que junto dela passa, em honra do jovem. 7. Ali deixou os dois irmãos de Soloente, a fim de governarem a cidade e a dotarem de legislação. Com eles deixou também Hermos, um dos Eupátridas de Atenas. Por causa do nome deste último, os habitantes de Pitópolis designam um determinado

${ }^{94} \mathrm{~A}$ identidade deste historiógrafo helenístico é também incerta. 
lugar na cidade por "morada de Hermes", ${ }^{95}$ dando uma entoação incorrecta à segunda sílaba da palavra, que passaram a acentuar, e assim concederam a um deus a honra que era própria de um herói.

27. 1. Esta foi, por conseguinte, a causa da guerra das Amazonas. E não parece ter sido empresa de pouca monta nem tarefa própria de mulheres. De facto, as Amazonas não teriam podido montar acampamento na cidade, nem encetar um combate corpo a corpo nas proximidades da Pnix ${ }^{96}$ ou do Museu, se não tivessem convergido para a cidade depois de terem facilmente dominado a regiáo. 2. Que lá chegaram, conforme relata Helânico, depois de terem atravessado o Bósforo Cimérico, coberto de gelo, é coisa difícil de acreditar. Mas que elas montaram acampamento praticamente dentro da cidade testemunham-no a toponímia e os túmulos dos que caíram na luta. Durante muito tempo hesitaram ambas as partes, sem que tomassem decisão para atacar. Mas, por fim, Teseu atacou, depois de ter feito um sacrifício ao Temor, na sequência de um oráculo.

3. A batalha deu-se no mês de Boedrómion..$^{97} \mathrm{Em}$ sua memória os Atenienses celebram até aos nossos dias

${ }^{95}$ É que o nome do deus Hermes, tem um genitivo acentuado na primeira sílaba (gr. Hérmou) enquanto o antroponímico Hermos tem um genitivo acentuado na última sílaba (gr. Hermoú).

${ }^{96}$ A Pnix é a colina rochosa, a Oeste da Acrópole. Aí reunia, entre o séc. VI e IV a. C. a Assembleia (gr. Ekklesia). O Museu (gr. Mousaion) é a colina que se encontra frente à Acrópole, do lado sul, e onde se acreditava estar sepultado o poeta do mesmo nome.

${ }^{97}$ Terceiro mês do calendário ático (corre de meados de Setembro a meados de Outubro). 
as Boedrómias. Clidemo, levado pelo desejo de tudo descrever com exactidão, refere que a ala esquerda das Amazonas se estendia até um lugar hoje denominado Amazónion e que a ala direita chegou até à Crisa, ${ }^{98}$ perto da Pnix. 4. Afirma que contra este flanco combateram os Atenienses que partiram do Museu para as atacar e que os túmulos dos generais caídos se encontram à beira da grande via que conduz à porta, agora conhecida como "porta do Pireu", junto ao monumento do herói Calcodonte. ${ }^{99} 5$. Deste lado os combatentes perderam terreno perante estas mulheres e foram obrigados a recuar até ao santuário das Euménides. ${ }^{100}$ Em contrapartida, os que atacaram a partir do Paládio, de Ardeto e do Liceu caíram sobre a ala direita das Amazonas e obrigaram-nas a recuar até ao acampamento, depois de lhes infligirem muitas baixas. No quarto mês de contenda foi celebrado um acordo de paz por intermédio de Hipólita - pois Clidemo chama Hipólita e não Antíope à Amazona que vivia com Teseu.

6. Alguns autores afirmam que esta mulher, quando combatia nas fileiras de Teseu, sucumbiu a um golpe de lança de Molpádia e que a estela que se encontra junto ao templo de Terra Olímpica foi aí erigida em sua memória. Não é de admirar que assim variem as versôes em relação a acontecimentos tão antigos. Conta-se

${ }^{98}$ Não se conhece a situação deste espaço de culto, ou memorial.

${ }^{99}$ Calcodonte, filho de Abas, rei dos Abantes, era um herói da ilha de Eubeia.

100 Situado logo abaixo do Areópago (cf. Ésquilo, Euménides, v. 1013). 
também que Antíope enviou às ocultas para a Cálquide as Amazonas feridas, que elas aí receberam tratamento e que algumas lá foram enterradas, nas imediaçóes do lugar que hoje tem o nome de Amazónion. 7. Mas que a guerra terminou com um tratado dá-nos testemunho a designação do lugar junto ao Teseion, denominado Horcomósion, ${ }^{101}$ e o sacrifício que, desde tempos remotos, se faz em honra das Amazonas, antes das festas de Teseu.

8. Também os habitantes de Mégara exibem um túmulo das Amazonas existente na sua terra, no caminho que conduz da ágora ao lugar chamado Róo, no sítio onde se encontra o Rombóide. Conta-se que outras morreram em Queroneia e que foram sepultadas nas margens de um regato que, ao que parece, se chamava antigamente Termodonte e hoje tem o nome de Hémon. Deste assunto falei na Vida de Demóstenes.

9. É certo que as Amazonas náo atravessaram a Tessália sem combater. De facto, ainda hoje se podem ver aí túmulos seus, junto a Escotusseia e nas Cinoscéfalas.

28. 1. Estes são os factos respeitantes às Amazonas que merecem ser recordados. $\mathrm{O}$ autor do poema Teseida ${ }^{102}$ refere que a causa da guerra das Amazonas foi

${ }^{101}$ Horkos é o termo grego para 'juramento'.

${ }^{102}$ Este poema e a sua autoria e datação póem sérios problemas. WALKER (1995) 38-39 apura que deveriam ter corrido dois poemas, pelo menos, com este nome, mas nenhum deles remontaria à época dos Pisístratos - não poderia, pois, estar relacionado com a passagem de Teseu, no mito, a herói político. 
o casamento de Teseu com Fedra, que levou Antíope a atacá-lo, por vingança, com as suas Amazonas e que Héracles as matou. Esta versão parece ser manifestamente uma fábula, uma ficção. 2. Teseu só veio a desposar Fedra depois da morte de Antíope, de quem tinha um filho, Hipólito, ou Demofonte, como Píndaro o denomina.

3. Quanto aos infortúnios sofridos por Teseu com respeito a Fedra e a seu filho, como não há contradição entre os historiadores e os tragediógrafos, é de crer que tivessem sucedido como uns e outros, sem discordância, os apresentam.

29. 1. Há, no entanto, outros relatos sobre amores de Teseu que não foram levados à cena e que nem têm um começo digno nem um feliz desenlace. Diz-se, de facto, que ele raptou uma tal Anaxo, de Trezena e que, depois de ter morto Sínis e Cércion, violentou as suas filhas, que desposou Peribeia, mãe de Ájax, e depois Ferebeia e Íope, filha de Íficles. 2. E por amor de Egla, filha de Panopeu, conforme se diz, é apontado como responsável por ter abandonado Ariadne de forma pouco nobre e decente. Mas o rapto de Helena, em particular, espalhou a guerra pela Ática e acabou por o levar ao exílio e à morte. Deste assunto se falará um pouco mais adiante.

3. Embora os heróis desses tempos se envolvessem em empresas numerosas, Teseu, na opinião de Herodoro, não participou em nenhuma delas a não ser na luta entre os Lápitas e os Centauros. Em contrapartida, outros 
pensam que ele acompanhou Jasão, até à Cólquide, ${ }^{103} \mathrm{e}$ que ajudou Meleagro a exterminar o javali e que daí vem a expressão "nada sem Teseu". Diz-se ainda que, por si só e sem o auxílio de qualquer aliado, levou a cabo numerosas e belas empresas e que por isso prevaleceu, a seu respeito, a expressão "ele é um segundo Héracles".

4. Ajudou Adrasto a recuperar os corpos dos guerreiros caídos junto à cidade de Cadmo, ${ }^{104}$ não conforme Eurípides o apresenta numa sua tragédia, após ter vencido os Tebanos em batalha, mas pela persuasão e por um acordo de tréguas. É o que diz a maioria dos autores. Filócoro afirma até que este foi o primeiro acordo celebrado para recuperação de cadáveres. 5. Mas que foi Héracles quem, pela primeira vez, entregou o corpos dos guerreiros mortos aos inimigos, consta da biografia deste herói. Os túmulos dos soldados de Adrasto podem ser vistos em Elêuteras, os dos seus comandantes estáo em Elêusis. E esse foi outro favor concedido por Teseu a Adrasto. Contraditam as Suplicantes de Eurípides os Eleusinios de Ésquilo, peça na qual que o dramaturgo pôe na boca de Teseu o que acabo de dizer.

30. 1. Quanto à amizade deste com Pirítoo, ${ }^{105}$ dizse que nasceu do seguinte modo. Teseu gozava de extraordinária fama, quer pela sua força, quer pela sua cora-

${ }^{103} \mathrm{Na}$ empresa dos Argonautas, em busca do Velo de Ouro.

${ }^{104} \mathrm{Na}$ guerra travada contra Tebas por Polinices, filho de Édipo, com os sete esquadróes aliados.

${ }^{105}$ Pirítoo, rei dos Lápitas e filho de Íxion (Homero dá-o como filho do próprio Zeus: Ilíada 2. 741) começa por ser um herói tessálico. A sua amizade com Teseu tornou-se paradigmática. 
gem. Então Pirítoo, desejoso de o experimentar e pôr à prova, roubou de Maratona bois que eram pertença de Teseu. Quando soube que este se armara e se pusera no seu encalce, não lhe fugiu - pelo contrário: voltou atrás para o defrontar.

2. Quando se avistaram mutuamente, cada um deixou-se tomar de admiração pela beleza e pela coragem do outro e renunciaram ambos ao confronto na luta. Então Pirítoo tomou a iniciativa de lhe estender a máo pedindo que fosse o próprio Teseu a servir de juiz do roubo dos bois, pois submeter-se-ia por sua livre vontade à pena que este determinasse. Mas Teseu não só o isentou de castigo como lhe solicitou que se tornasse seu amigo e aliado. Selaram, então, com um juramento, um pacto de amizade.

3. Depois deste episódio, Pirítoo desposou Deidamia ${ }^{106}$ e convidou Teseu para vir à cerimónia, visitar a sua terra e ficar entre os Lápitas. Ora Pirítoo havia também chamado os Centauros para o banquete. Como estes começassem a exceder-se e a comportar-se com insolência, e, sob o efeito da embriaguez, perseguissem as mulheres, os Lápitas lançaram-se em defesa destas e mataram alguns Centauros. Os restantes foram vencidos em batalha e expulsos do território. Teseu combateu em defesa dos Lápitas e participou na batalha.

4. Herodoro, porém, afirma que os factos não se passaram deste modo, mas que foi já depois de a guerra ter estalado que Teseu veio prestar apoio aos Lápitas

${ }^{106}$ Outras fontes conhecem-na como Hipodamia (cf. Ilíada 2. 742). Era filha do rei Adrasto. 
como seu aliado e que foi então que, pela primeira vez, avistou Héracles com os seus próprios olhos. Encontrou-o em Tráquis, quando este já havia encontrado repouso das suas andanças e dos seus trabalhos. Foi então que se estabeleceu a estima e a amizade entre eles e mutuamente teceram enormes elogios. No entanto, é preferível seguir quem afirma que eles se encontraram muitas vezes e que Héracles foi iniciado nos mistérios por Teseu e que este também o purificou antes da iniciação, pois assim se tornava necessário, devido a actos que aquele cometera involuntariamente. ${ }^{107}$

31. 1. Já chegado aos cinquenta anos, segundo Helânico, Teseu raptou Helena, sem ter em conta a idade de ambos. ${ }^{108}$ Há quem diga, para o desculpar deste delito - que foi de todos o acto mais grave de que o acusam -, que náo foi ele o raptor, mas Ida e Linceu, ${ }^{109}$ que, depois de a terem raptado, a confiaram à sua guarda e ele se comprometeu a não a entregar aos Dioscuros, pese

107 É de notar o modo como Plutarco evita ser mais incisivo e concreto ao referir-se aos actos de Héracles. Trata-se da morte infligida por este a sua esposa Mégara e a seus filhos, por acção do acesso de loucura que Hera lhe havia suscitado. Este episódio mitológico é dramatizado por Eurípides no seu Héracles.

${ }^{108}$ Como nota AMPOLO (1993) comm. ad 31. 1, este deve ser um dos cometimentos de Teseu de tradição mais antiga. $\mathrm{O}$ facto de Etra, mãe de Teseu, estar presente em Tróia, na Ilíada (3. 143144), como aia de Helena, atesta indirectamente o envolvimento de Teseu num rapto anterior. $\mathrm{O}$ motivo aparece já representado em cerâmica de inícios do séc. VII a. C.

${ }^{109}$ Gémeos filhos de Afareu, rei dos Messénios. Representam a réplica messénia dos Dioscuros espartanos, Castor e Pólux, irmãos de Helena. 
embora estes lha terem pedido. Outros aventam - por Zeus! - que o próprio Tindáreo a entregou a Teseu, movido pelo receio de Enársforo, filho de Hipocoonte, ${ }^{110}$ que queria ter Helena à força, embora ela fosse ainda uma criança. 2. No entanto, a versão mais verosímil e a dispor de documentação é a seguinte: os dois amigos, Teseu e Pirítoo, dirigiram-se a Esparta e raptaram a jovenzinha que dançava no templo de Ártemis Ortia, ${ }^{111}$ para fugirem em seguida. Os homens enviados no seu encalce não passaram para além de Tegeia.

Quando os raptores atravessaram o Peloponeso e se sentiram em segurança, decidiram fazer sortes, sendo que aquele a quem Helena coubesse deveria ajudar o outro a arranjar casamento. 3. O sorteio efectuou-se como combinado, e foi Teseu quem obteve o prémio. Tomou a jovenzinha, que ainda náo estava em idade de casar, e escoltou-a até Afidnas. Instalou sua mãe junto dela e confiou-as a Afidno, seu amigo, com a recomendação de a guardar e a esconder de estranhos. 4. Teseu, por seu turno, para retribuir a Pirítoo a ajuda recebida, acompanhou-o ao Epiro, no intuito de chegarem à presença da filha de Edoneu, o Molosso. ${ }^{112}$ Edoneu havia

${ }^{110}$ Hipocoonte era meio-irmão de Tindáreo e Icário, a quem afastou de Esparta, para ocupar o trono. Por se ter negado a purificar Héracles e por os seus filhos terem morto Eono, Héracles atacou-os, matando dez dos vinte filhos de Hipocoonte e repondo Tindáreo no trono de Esparta..

${ }^{111}$ Esta versão do mito estaria relacionada com uma dança cultual de donzelas no templo da deusa. Sobre o culto da deusa, em Esparta, com intervenção pública (de canto e gesto ritmado) nos dá já testemunho o Grande Partenéion do poeta Álcman.

${ }^{112}$ Este é um dos passos que melhor documenta a racionalização 
dado a sua esposa o nome de Perséfone e a sua filha o de Core, assim como pôs ao cão o nome de Cérbero. Com este haviam de combater os pretendentes da jovem, por ordem do rei. Aquele que vencesse, obteria a sua mão. 5. Informado de que os dois estrangeiros não vinham para a pedir em casamento ao pai, mas para a raptar, Edoneu aprisionou-os. A Pirítoo, fê-lo desaparecer de imediato por obra do cão. Quanto a Teseu, manteve-o como prisioneiro.

32. 1. Durante este tempo Menesteu, filho de Peteu que, por sua vez, era filho de Orneu e neto de Erecteu, tornou-se o primeiro homem, segundo se diz, a dedicar-se à prática da demagogia e a discursar à multidão para granjear as suas boas-graças, congregar e suscitar agitação dos poderosos, que já de há muito nutriam má vontade contra Teseu. É que entendiam que ele havia privado cada um dos Eupátridas do poder e soberania no seu próprio demo, para os juntar a todos numa só cidade, onde passou a tratá-los como súbditos e escravos.

Menesteu atiçava a multidão e provocava-a, dizendo que ela via só um sonho de liberdade, mas que, na realidade, se encontrava privada de um solo pátrio e de santuários e que tinham substituído os vários reis, nobres e legítimos, por um só déspota, um estrangeiro em quem tinha os olhos postos.

2. Enquanto Menesteu se dedicava a estas maquinaçóes, a invasão dos Tindáridas veio a

do mito, convertendo o episódio da descida ao Hades dos dois amigos num episódio terreno, à luz do dia. 
conferir uma enorme força à revolta. Há quem sustente a tese de que estes foram incentivados por Menesteu a promover a invasão. Primeiramente, os Tindáridas não cometeram agressóes, apenas reclamaram a irmá. 3. Mas depois de os habitantes de Atenas responderem que náo a retinham na cidade nem sabiam onde ela se encontrava escondida, recorreram à guerra.

Então Academo, ${ }^{113}$ que de algum modo soubera do paradeiro de Helena, revelou-lhes que a jovenzinha se encontrava escondida em Afidnas.

4. Aí têm a sua razão de ser as honras prestadas pelos Tindáridas a este herói, em sua vida e posteriormente, por ocasião das várias incursóes dos Lacedemónios em terra da Ática: estes devastaram toda a região mas pouparam a Academia, por respeito a Academo.

5. Dicearco, porém, afirma que dois homens da Arcádia, Equedemo e Marato, acompanharam os Tindáridas na sua expedição militar e que é do nome do primeiro que deriva o de Equedemia, que deu lugar à actual designação de Academia, ao passo que o nome do demo de Maratona decorre do nome do onomástico do segundo que, para cumprir um oráculo, se ofereceu para ser voluntariamente sacrificado antes do combate. 6. Os Dioscuros chegaram a Afidnas, saíram vitoriosos do confronto e destruíram o lugar. Foi aí, segundo se diz, que perdeu a vida Hálico, filho de Escíron, ao tomar parte na peleja ao lado dos Dioscuros. É essa a razão

${ }^{113}$ Figura ateniense que, convertida em herói, terá consagrado um jardim, no qual Platão ensinava - a Academia, que ao herói deve o nome. 
de ser de um topónimo da região de Mégara - o do local onde Hálico está sepultado. 7. Héreas conta que ele foi morto às máos de Teseu em Afidnas e dá estes versos como testemunho da sorte de Hálico:

Aquele a quem, na vastidão de Afidnas, no combate por Helena de belos cabelos, Teseu matou...

Não é, contudo, verosímil que, se Teseu estivesse presente, sua mãe tivesse sido feita prisioneira e Afidnas houvesse sido tomada.

33. 1. Com a conquista de Afidnas apoderou-se o medo dos cidadãos de Atenas. Menesteu persuadiu o povo a receber os Tindáridas na cidade e a tratá-los como amigos, já que só faziam guerra contra Teseu, que os havia ultrajado primeiro, e que se comportavam, em relação a todas as outras pessoas, como benfeitores e protectores. ${ }^{114}$ Testemunhava-o a sua conduta. Na verdade, ainda que fossem senhores de tudo, nada exigiram para si, excepto serem iniciados nos Mistérios, já que a sua ligação à cidade não era menor que a de Héracles. 2 . Esta exigência foi atendida e Afidno adoptou-os como filhos, tal como Pílio o fizera com Héracles. Receberam até honras devidas aos deuses, sob o nome de Ánaces, ${ }^{115}$

${ }^{114}$ Consoante nota AMPOLO (1993) comm. ad. 33. 1, todo este capítulo constitui uma explicação etiológica do culto ático dos Dioscuros.

${ }^{115}$ Esta engenhosa explicação não é correcta. Anakes não é mais que um antigo nominativo plural de anax, correspondente ao mais 
quer pelas tréguas estabelecidas, quer pelo zelo e preocupação manifestados de que ninguém sofresse dano devido à presença de um táo vasto exército dentro da cidade. Diz-se, de facto, de quem mantém alguma coisa ao seu cuidado ou à sua guarda, que se comporta com solicitude. É por isso, talvez, que os reis são denominados anaktes. 3. Mas há quem defenda que é devido à aparição dos seus astros recebem o nome de Ánaces. É que os Atenienses indicam o que está no alto com o termo anekas e anekathen o que vem de cima.

34. 1. Etra, a mãe de Teseu, foi feita prisioneira e levada, ao que dizem, para a Lacedemónia, e de lá para Tróia, com Helena. Homero atesta que ela seguiu Helena quando diz: ${ }^{116}$

Etra, filha de Piteu, e Clímene de olhos grandes.

2. Outros, no entanto, refutam este verso como suspeito, tal como a lenda de Múnico, ${ }^{117}$ de quem contam que, nascido dos amores clandestinos de Demofonte e Laódice, foi criado em Ílion por Etra. 3. Uma história particular e completamente fora de contexto é a que

recente, anaktes. A palavra significa 'senhor' e emprega-se para reis soberanos e para deuses.

${ }^{116}$ Iliada 3. 144.

117 Concordo com PÉREZ JIMÉNEZ (1985) 200-201 n.129: não se trata do herói epónimo de Muníquia, mas de um outro, mais conhecido como Múnito, filho dos amores de Laódice, por sua vez filha de Príamo e Hécuba. 
conta Istro, ${ }^{118}$ no livro treze da sua História da Ática, a propósito de Etra. Ele refere que, segundo alguns autores, quando Páris-Alexandre foi vencido por Aquiles e por Pátroclo nas margens do Esperqueio, Heitor tomou a cidade de Trezena, saqueou-a e levou Etra consigo como prisioneira. Mas esta história é completamente absurda.

35. 1. Edoneu, o Molosso, ao acolher Héracles como hóspede, referiu-se, casualmente, ao que aconteceu a Teseu e a Pirítoo, com que intenção tinham vindo e que castigo lhes aplicou após terem sido descobertos. Héracles ficou profundamente tocado pela morte inglória que um tivera e que o outro também iria ter. 2. Quanto à sorte de Pirítoo, pensou Héracles, nada mais poderia fazer que manifestar a sua reprovação, mas intercedeu pela vida de Teseu e pediu ao rei que lhe fosse concedida essa graça. 3. Edoneu concordou e Teseu, uma vez libertado, regressou a Atenas, onde os seus amigos não tinha sido completamente aniquilados. Então, quantos recintos lhe haviam sido consagrados outrora pela cidade, todos eles, à excepção de quatro, ele os dedicou a Héracles, mudando-lhes o nome de Teseia para Heracleia. É Filócoro quem o refere. 4. Logo após estas medidas, quis assumir, como dantes, o governo da cidade e dirigir os assuntos de Estado, mas viu-se envolvido em conspiraçóes e revoltas. Apercebeu-se, então, que aqueles que já o odiavam antes de se ausentar haviam

${ }^{118}$ Historiógrafo do séc. III a. C., ao que parece discípulo de Calímaco. 
acrescido ao ódio a perda de medo que por ele tivessem e que o povo, por seu turno, profundamente corrompido, desejava ser servido e não cumprir ordens em silêncio. 5. Recorreu, então, à força, mas foi combatido por demagogos e conspiradores. Por fim, desesperado com o estado das coisas, enviou os seus filhos em segredo para a Eubeia, para junto de Elefenor, ${ }^{119}$ filho de Calcodonte. Quanto a ele mesmo, uma vez em Gargeto, lançou maldiçôes contra os Atenienses num lugar que, ainda hoje, é conhecido por Aratérion ${ }^{120}$ e, de seguida, zarpou para Esciro, pois contava com a amizade dos seus habitantes, pensava ele, e possuía, na ilha, terras herdadas de seu pai.

6. Era Licomedes quem reinava, ao tempo, sobre os Escírios. Ao chegar à sua presença, Teseu pediu que lhe fossem entregues as suas terras, para aí se estabelecer. Há quem diga que ele solicitou auxílio contra os Atenienses. Licomedes, porém, fosse por receio da fama de Teseu, fosse para cair na boas-graças de Menesteu, levou-o até ao ponto mais alto da ilha, como para lhe mostrar de lá as suas terras, e precipitou-o do alto dos penhascos, dando-lhe morte. 7. Outros afirmam que Teseu caíu por ele mesmo enquanto passeava depois de comer, como era seu costume. Naquela altura ninguém comentou a sua morte. Menesteu reinava em Atenas, enquanto os filhos de Teseu viviam, como simples privados, em casa de Elefenor, que acompanharam na expedição a Ílion. 8. Ora Menesteu teve o seu fim em Tróia e eles regressaram

${ }^{119}$ Neto de Abas.

${ }^{120}$ Literalmente o nome significa 'lugar das maldiçôes' 
a Atenas e recuperaram o poder. Posteriormente, motivos de diversa ordem levaram os Atenienses a prestar honras de herói a Teseu. E não foram poucos os combatentes contra os Persas, em Maratona, que acreditaram ter avistado o espectro de Teseu, armado, avançando contra os bárbaros em defesa da sua causa.

36. 1. Depois das Guerras Persas, no arcontado de Fédon, ${ }^{121}$ a Pitonisa uma vez consultada pelos Atenienses, ordenou-lhes que recolhessem os ossos de Teseu, lhes dessem sepultura perene em Atenas e lhe prestassem culto. Era, no entanto, impossível resgatá-los e encontrar o lugar onde estavam enterrados, devido ao trato insociável e rude dos Dólopes, que habitavam a ilha. 2. No entanto, quando Címon conquistou a ilha, conforme relatei na sua Vida, ${ }^{122}$ pôs todo o seu empenho na descoberta do túmulo. ${ }^{123}$ Apercebeu-se, um dia, segundo se conta, que uma águia, por casualidade providencial, golpeava com o seu bico uma elevação de terreno e a escavava com as suas presas. Címon compreendeu o sinal e aí escavou. Nesse lugar foi, então, encontrado o túmulo de um homem de grande estatura, com uma lança e uma espada de bronze a seu lado. 3 . Címon transportou para Atenas os restos mortais, na sua trirreme. Foi com júbilo que os Atenienses os receberam, com luzidos cortejos e esplêndidos sacrifícios,

${ }^{121} \mathrm{O}$ arcontado de Fédon, ao que parece, decorreu nos anos de 476-475 a. C.

122 8. 3-7

${ }^{123}$ Sobre a valorização da figura de Teseu no contexto da política de Címon vide WALKER (1995) 55-61. 
como se Teseu, em pessoa, estivesse de regresso à cidade. 4. Está sepultado no meio da cidade, junto ao actual Ginásio. O seu túmulo constitui um lugar de refúgio para os escravos, para todos os humildes e para os que temem os poderosos, já que também Teseu tinha desempenhado o papel de protector e defensor e acolhia com humanidade as súplicas dos mais desfavorecidos. A festa mais importante em sua honra tem lugar a oito do Pianépsion, data correspondente àquela em que regressou de Creta com os seus jovens companheiros. 5. Também se celebra, em sua honra, o dia oito de cada mês, seja porque ele chegou a Atenas, pela primeira vez, vindo de Trezena, no oitavo dia do Hecatombéon, consoante o relato de Diodoro o Periegeta, ${ }^{124}$ seja porque nenhum outro número combina melhor com ele, na sequência da tradição que o deu como filho de Poséidon. 6. É que, de facto, o culto de Poséidon tem lugar no dia oito de cada mês. Efectivamente, o número oito, por ser o cubo do primeiro par e o dobro do primeiro quadrado, contém a firmeza e a estabilidade própria deste deus, a quem chamam Asfálio ${ }^{125}$ e Géoco. ${ }^{126}$

${ }^{124}$ A sua obra data de cerca de 300 a. C.

${ }^{125}$ Lit. 'deus que dá segurança'.

${ }^{126}$ Lit. 'deus que tem a terra'. Sobre outra interpretação veja-se AMPOLO (1993) comm. ad 36. 6. 
VidA DE Rómulo 


\section{INTRODUÇÃO}

$\mathrm{Na}$ altura em que o biógrafo compunha as Vitae, os dados relativos à fundação de Roma estavam já perfeitamente cristalizados e, porque Plutarco não se desvia muito das grandes linhas da vulgata fixada pelo tempo, valerá a pena recordar os pontos essenciais da tradição, bem como os aspectos sujeitos a maior controvérsia, uma vez que os vamos reencontrar, regra geral, na Vida de Rómulo, embora filtrados pela sensibilidade ética e estética do autor e ainda pela preocupação de não hostilizar os Romanos, cuidado aliás facilmente compreensível na óptica de um grego que reconhecia e não deixava de apreciar o poder e capacidade de organização dos dominadores latinos.

Assim, a maioria das fontes antigas aceitava que Rómulo e Remo haviam nascido de Reia Sílvia, filha do rei Numitor, o legítimo herdeiro do trono albano, e que fora deposto pelo irmão Amúlio. Como forma de prevenir a eventual reivindicação do sólio por algum descendente de Numitor, Amúlio obrigou a sobrinha a fazer-se Vestal. Dado que as servidoras de Vesta tinham de permanecer virgens, o nascimento dos gémeos encontrava-se, de certa forma, envolto em polémica e infracção, o que teria facilitado a decisão de Amúlio de mandar lançar as crianças ao Tibre. Da piedade ou receio da pessoa encarregada de cumprir a sentença resultou que os dois irmãos foram colocados numa cesta que, ao ser arrastada rio abaixo pela correnteza, acabaria depositada no banco de areia de uma das margens. Uma 
vez aí, os gémeos começaram por ser amamentados por uma loba, até que uns pastores os recolheram e criaram. Rómulo e Remo cresceram nesse meio, ignaros da verdadeira identidade, embora as suas naturais qualidades de liderança os projectassem como chefes dos companheiros, que se envolviam em frequentes escaramuças e bravatas com outros pegureiros, piratas e ladróes que actuassem na região. Ao tomarem conhecimento da real ascendência, os gémeos atacaram Alba Longa e repuseram no trono o avô, Numitor, embora optassem por não permanecer na cidade, cujo governo lhes caberia mais tarde por direito. Em vez disso, decidiram fundar uma colónia de Alba Longa, no local onde haviam sido salvos. A nova urbe acabaria por chamar-se Roma, designação que derivaria de Rómulo, depois de ele ter assassinado o irmão numa querela fútil, por alturas da delimitação das muralhas da cidade. Roma conheceu um crescimento rápido, devido sobretudo à grande capacidade de integraçáo e acolhimento de outras pessoas, mesmo de elementos marginais e potencialmente perigosos, se bem que o futuro a médio prazo se visse comprometido pela falta de mulheres; daí o episódio do rapto das mulheres sabinas e posterior integração dos Sabinos, traduzida na partilha do governo entre Rómulo e Tito Tácio. Roma continuou a aumentar em poder e importância demográfica, numa expansão rápida, justificada essencialmente por dois factores: por um lado, a poderosa força bélica, que ora atraía e forçava a celebração de alianças com os vizinhos ora permitia infligir pesadas derrotas aos inimigos; por outro, a enorme capacidade para absorver 
elementos externos, fossem imigrantes, confederados ou mesmo as partes vencidas em conflito.

Apesar da concordância genérica em relação a estes elementos, as fontes não deixam, ainda assim, de comportar inúmeras disputas e variantes no respeitante a questóes de pormenor. Valerá a pena evocar, igualmente, os principais dados objecto de discussão. A controvérsia começava logo pela paternidade dos gémeos. A maioria das fontes apontava o deus Marte, solução que reunia evidentes vantagens: enobrecia as origens de Roma, ao misturar elementos humanos e divinos, além de que ter Marte como pai era um cenário muito conveniente a um povo que se afirmara pela capacidade bélica ou 'marcial'; para mais, esta solução ilibava Reia Sílvia da acusação de não ter observado voluntariamente a castidade. Ainda assim, havia outros candidatos à paternidade, como um espectro saído da terra (hipótese que salvaguardava a ideia de intervenção divina) ou simplesmente o próprio Amúlio, que se disfarçara de Marte para violentar a sobrinha. Objecto de especulação era ainda a identificação da loba que amamentara os gémeos. De facto, em Latim, o termo lupa é ambíguo, pois tanto pode significar 'loba' como 'prostituta', de modo que a racionalização do mito implicava táo-somente a diferença entre uma leitura enobrecedora ou, muito pelo contrário, aviltante. Idêntica discussão motivava o contexto em que ocorrera a morte de Remo, oscilando os juízos entre a recriminação aberta de Rómulo (que vinha enganando o irmão já desde a consulta do voo das aves, a propósito da decisão sobre o nome e localização 
da futura cidade) ou as tentativas de desculpabilização, assumindo que havia sido antes um companheiro de armas (Célere) a desferir o golpe mortal. Rómulo enfrentava a mesma ambivalência interpretativa relativamente às circunstâncias que levaram ao assassinato do sabino Tito Tácio ou à sua própria morte. No primeiro caso, era, no mínimo, acusado de alguma incúria na maneira como procurara fazer justiça à morte do colega de governo, chegando inclusive a enfrentar a suspeita de ele mesmo ter organizado o golpe, a fim de ficar sozinho à frente de Roma. Quanto ao desaparecimento do seu corpo, no termo de uma progressiva cedência aos vícios da tirania, especulava-se se teria ocorrido por conjura do senado se por intervenção divina: por outras palavras, se o homicídio fora politicamente motivado ou se se tratara antes da apoteose do herói fundador.

$\mathrm{Na}$ altura em que decidiu compor a Vita de Rómulo, Plutarco tinha à disposição este acervo de informaçóes, produto de um longo e intricado processo de transmissão, que combinava elementos do conto popular, mitologia e recriação literária, erudição histórica e especulação antiquária. Para seleccionar um tipo de material que remontava a um período muito distante e, conforme dissemos na "Introdução Geral", entrava mais no plano mítico do que no domínio da história, Plutarco serve-se do logos para efectuar um processo de racionalização mitigada que se traduz, sobretudo, em dar preferência a versóes com maior verosimilhança e mais atestadas pelas fontes. No entanto, o biógrafo nem sempre toma partido em relação às diferentes interpretaçóes 
racionalizantes, optando por vezes por enumerar simplesmente as distintas abordagens; é o que acontece, por exemplo, com o episódio de Aca Larência (Rom. 4.3-4). Mostra-se ainda, como acontecia já com a Vita de Teseu, particularmente céptico em relação a certas variantes literárias, que vão contra a probabilidade histórica, conforme ilustra o juízo acintoso relativamente ao poeta Símilo pela forma como tratou o episódio de Tarpeia (Rom. 17.6-7), ou ainda a retracçáo perante a maneira como Butas explica o ritual dos Lupercalia (Rom. 21.8). ${ }^{1}$ Já a grande renitência com que trata a hipótese de o corpo de Rómulo (Rom. 28) ascender aos céus juntamente com a alma parece entrar mais no domínio das convicçóes ético-filosóficas de Plutarco, uma vez que o biógrafo não se empenha propriamente em negar a apoteose do herói, mas antes a ideia de corpo e alma participarem em conjunto nesse processo, conforme argumenta, em termos que valerá a pena evocar (Rom. 28.10): ${ }^{2}$

Não é, portanto, necessário forçar a natureza para fazer subir aos céus o corpo das pessoas de bem, mas pode-se crer com segurança que as suas virtudes e almas, de acordo com

${ }^{1}$ Ainda assim, a tendência para aceitar como verdadeiros os relatos que vão ao encontro de práticas rituais inscreve-se numa longa tradição historiográfica, que Plutarco também não deixa de seguir como critério valorativo, pese embora o risco de as explicaçôes etiológicas poderem funcionar como argumentação circular: usam-se os cultos como forma de tornar plausíveis determinadas lendas e utilizam-se alguns relatos míticos (entendidos como repositório da memória colectiva e da identidade cultural) para explicar certos cerimoniais, ligando-os às raízes profundas do passado mais remoto.

${ }^{2}$ Cf. também Sobre o E de Delfos 390 d-f. 
a natureza e com a justiça divina, ascendam da condição humana à de heróis, de heróis a semi-deuses e, finalmente, que de semi-deuses - como na iniciação mistérica, depois de se purificarem e santificarem, libertando-se de todos os elementos mortais e sensíveis - sejam elevadas a deuses; contudo, isso não acontece por decreto da cidade, mas segundo a verdade e a lógica aceitável, desta forma atingindo o fim mais belo e mais ditoso.

A este conjunto de factores que actuaram sobre a forma de trabalhar as fontes, convém juntar um outro, não menos importante e cuja influência se estende às restantes Vitae; referimo-nos às regras específicas do género biográfico, que implicam uma estética própria de selecção e arranjo do material disponível. Isso mesmo nos recorda Plutarco na abertura de algumas biografias, a fim de prevenir eventuais críticas dos leitores, preocupação idêntica à que demonstra relativamente à explicação para a escolha do par Teseu-Rómulo, conforme se viu, e que torna os proémios deste tipo num espaço privilegiado para abordar algumas questóes de carácter teórico e metodológico. ${ }^{3}$ De facto, na abertura do prefácio às Vitae de Timoleonte e de Emílio Paulo (1.1), Plutarco informa que começou por se dedicar à elaboração de biografias a pedido de amigos, entre os quais se contavam personalidades importantes, tanto gregas como romanas. Contudo, a essa motivação cedo ele juntou o gosto e proveito pessoais decorrentes do convívio com o

${ }^{3}$ Neste ponto, retomámos alguns dos argumentos usados em LEÃo (2005a) 23-25. 
exemplo das grandes figuras do passado. Portanto, será de admitir que a elaboração de uma espécie de 'espelho de virtudes' é que constitui o objectivo principal da sua escrita biográfica. No entanto, a concomitância, no passo agora referido, do termo historia levou muitos investigadores a procurar descobrir em Plutarco as marcas da indagação histórica, com resultados nem sempre elogiosos para o autor das Vidas Paralelas. Ora na abertura da biografia de Alexandre Magno, ele responde precisamente a esta crítica (Alex. 1.1-2):

Ao escrevermos neste livrinho a biografia do rei Alexandre e de César (que derrubou Pompeio), não faremos outros preâmbulos, dada a grande quantidade de acontecimentos envolvidos, para além de formular um pedido aos leitores: de, no caso de não relatarmos em pormenor todo e cada um dos eventos célebres, mas antes abreviarmos a maior parte, nos não julgarem mal. Na verdade, nós não escrevemos histórias mas sim biografias, nem sequer é nos acontecimentos mais espectaculares que reside especialmente a demonstração da virtude ou do vício; pelo contrário, muitas vezes um pequeno gesto, uma palavra ou uma brincadeira reflectem melhor o carácter do que os combates com baixas incontáveis ou fileiras cerradas ou os maiores cercos a cidades.

Este preâmbulo, justamente célebre, não só define de maneira mais precisa a índole das Vitae como esclarece melhor os seus objectivos, que já se adivinhavam no passo da Vita de Timoleonte. Plutarco não pretende ser um historiador, mas antes um biógrafo. Por este motivo, pede aos leitores que lhe não censurem o facto de 
passar em branco acontecimentos que, pela sua importância, eram bem conhecidos e sobre os quais havia à disposição outros relatos de natureza histórica. Por conseguinte, Plutarco afirma-se um biógrafo, mas também não na forma plena em que hoje se entende o termo; as Vitae não pretendem descrever toda a carreira de determinado homem ou mesmo definir o lugar que ocupa na história, embora possam acabar por fazê-lo, até porque as personalidades retratadas correspondem geralmente a grandes estadistas do passado. Os feitos destes heróis, qualquer que fosse a sua natureza, só lhe interessavam na medida em que permitissem esclarecer a verdade sobre o carácter que possuíam essas personalidades de excepção, acentuando assim o seu valor exemplar.

Ora no caso de heróis fundadores (como acontece com o tratamento dado a Teseu e a Rómulo), o percurso biográfico escolhido assume ainda mais claramente o carácter de arquétipo, na medida em que essas figuras representam, de forma metonímica, uma espécie de 'genoma étnico’ (como atrás dizíamos) da civilização a que deram origem. Ainda assim, também neste processo de modelação os parâmetros da escrita de Plutarco estavam já praticamente definidos pela tradição anterior. Para ilustrar este facto, aliás bem conhecido, bastaria evocar o aproveitamento ideológico de Teseu na tragédia ática ou o de Rómulo na literatura imperial. Em boa verdade, do ponto de vista histórico, tanto a existência de Rómulo como os feitos que lhe vêm atribuídos são mais do que duvidosos. No entanto, ainda que se postule a 
hipótese teórica de ter vivido efectivamente alguém com o mesmo nome no séc. VIII a.C., essa pessoa não foi, seguramente, o 'fundador' de Roma, pois o lugar já era habitado havia bastante tempo e, além disso, as próprias lendas pressupóem que a construção da urbe se traduziu num processo gradual e lento, de forma que cada um dos reis teria sido, à sua maneira, também o fundador de uma parte da cidade. ${ }^{4} \mathrm{~A}$ ideia de um oikistes primordial que criasse o núcleo urbano a partir do nada afigura-se claramente influenciada pela historiografia grega e respectiva concepção do ritual de fundação (ktisis), acabando assim por gerar uma contradição dentro do cerne das lendas romanas.

Aliás, não é esta a única diferença clara e rica de consequências que encontramos entre o modelo helénico e romano. Os Gregos insistiam muito na noção de pureza originária, a ponto de os Atenienses, por exemplo, desenvolverem a crença de que os primeiros habitantes eram autochthones, isto é, haviam literalmente 'brotado do próprio solo' e, como tal, não tinham sido nunca estrangeiros ou colonos invasores. ${ }^{5}$ Pode parecer um pormenor sem importância, mas a verdade é que, de forma consciente ou não, acabava por ter importantes consequências a nível legal, sobretudo no que se referia ao direito de propriedade (enktesis) sobre terras e outros bens imóveis. Um estrangeiro com autorização de

${ }^{4}$ As palavras de Tito Lívio são, a este nível, de uma clareza meridiana (2.1.2: omnes deinceps conditores partium certe urbis). Cf. ainda Cícero, Rep. 2.37; Políbio, 6.10.12-14.

${ }^{5}$ Sobre esta questão, vide Leấ (2005b), esp. 53-68. 
residência oficializada e legal (como acontecia com um meteco) só obteria, mesmo assim, o direito à enktesis como sinal de reconhecimento e deferência especial e nunca em resultado das naturais expectativas de quem habitasse em território ático, ainda que o fizesse há muito tempo. ${ }^{6}$ Se avançarmos para o domínio dos direitos de cidadania, será fácil reconhecer que Atenas estabeleceu as noçôes básicas daquele estatuto, traduzidas no princípio da soberania popular e na igualdade de todos os cidadáos: perante a lei (isonomia), no acesso ao poder (isocracia) e na forma como gozavam da liberdade de expressão (isegoria). No entanto, da mesma forma que estabelecia a equivalência de todos os cidadãos perante a tutoria da lei, a democracia acentuava também os graus de exclusão, quer dentro do corpo cívico (no respeitante a mulheres e a menores) quer ainda e sobretudo fora dele (no tratamento dispensado a metecos, escravos e estrangeiros). No fundo, isto acaba por ser a expressão do próprio particularismo da pólis, cujos ideais de autonomia obrigavam à contenção demográfica dentro de certos limites e constituíram, de resto, o principal entrave à união política dos Gregos, embora os não impedisse de reconhecerem a partilha da mesma identidade cultural.

O padrão romano comporta diferenças significativas, que se podem encontrar precisamente nas lendas fundacionais em geral e na Vida de Rómulo em particular,

${ }^{6}$ Se quiséssemos encontrar um paralelo discutível mas ainda assim ilustrativo do alcance simbólico da interdição, quase poderíamos dizer que alienar uma parcela da terra nutriz seria quase como 'vender a própria mãe'. 
ajudando a identificar o tal 'genoma étnico' antes mencionado. A ambiguidade relativa ao termo lupa tanto acentua o carácter extraordinário dos proto-romanos como denota a capacidade para singrar na vida a partir de inícios muito prosaicos; em todo o caso, a mera hipótese de ser 'filho de uma prostituta' implica um padrão civilizacional distinto da preocupação em insistir na pureza étnica, como faziam os Ateniense. A morte de Remo, suscitada por uma querela fútil, bem como as dúvidas que acompanharam a morte de Tito Tácio e do próprio Rómulo, poderiam apontar para a relativa facilidade com que o assassínio político era usado em Roma, onde não faltam exemplos desta prática extrema, em particular na parte final na República e durante o Principado. Em todo o caso, é um expediente completamente distinto e muito menos humano que o mecanismo do ostracismo, desenvolvido pela experiência ática da democracia. $\mathrm{O}$ mesmo se pode afirmar relativamente à ideia de acolher marginais, ladróes e inimigos dentro do corpo de cidadáos, bem como quanto à generosidade na atribuição de asilo: desde a origem, Roma parece ter seguido o desígnio de integrar para poder crescer. $^{7}$ Aliás,

7 Também aqui havia curiosas analogias no campo legal; ao longo da sua história, os Romanos revelaram-se particularmente generosos na concessáo da cidadania e foi isso que lhes permitiu aumentar o corpo cívico para números impensáveis nas póleis gregas. No entanto e para nos mantermos dentro do paralelo com Atenas, enquanto a democracia era avara na concessão do direito de cidadania mas depois reconhecia igualdade perante a lei a todos os cidadãos, Roma seguia o processo contrário: concedia esse estatuto com relativa facilidade, criando porém um acentuado escalonamento no interior do corpo de cidadãos. 
Plutarco não deixou de registar este aspecto, ao comentar a forma como Rómulo lidou com o ataque de Ácron, rei de Cenina (Rom. 16.3):

Ora não só o dominou e abateu, como ainda pôs em fuga o exército, depois de entrar em combate, e conquistou também a cidade. Mesmo assim, não exerceu violência sobre os prisioneiros, mas ordenou-lhes que derrubassem as suas casas e o seguissem até Roma, onde se tornariam cidadãos com direitos iguais. Em boa verdade, foi esta atitude, mais do que qualquer outra razão, que permitiu a Roma tornar -se grande: conciliar consigo mesma e integrar sempre os povos que ia vencendo.

Surpreendem-se, portanto, nas atitudes do fundador algumas das marcas do 'código étnico' que haveria de caracterizar os herdeiros do mesmo património civilizacional. No termo desta breve análise, porém, temos de reconhecer que persiste a mesma dúvida programática: as lendas fundacionais foram recolhendo, ao longo do seu processo de formação, o essencial da Romanitas ou serão antes, pelo contrário, uma projecção no passado da forma como os Romanos se viam a si mesmos e gostavam de ser vistos pelos outros? A resposta para esta pergunta residirá, possivelmente, a meio caminho entre ambas as hipóteses formuladas. Em todo o caso, isso não altera - mas antes reforça - a dimensão paradigmática e simbólica da tradição reunida e tratada por Plutarco na Vida de Rómulo, a qual procurámos evocar ao longo deste estudo introdutório. 
VidA DE Rómulo 
1. 1. Sobre o grande nome de Roma, que a fama difundiu entre a humanidade inteira, sobre quem o teria dado e por que motivo o atribuiria à cidade, é matéria em relação à qual não há acordo entre os historiadores. De facto, uns sustentam que os Pelasgos, depois de andarem errantes pela maior parte da terra habitada e de terem vencido muitos povos, se fixaram aqui e deram este nome à cidade por causa da sua valentia em combate; ${ }^{1}$ outros afirmam que, por alturas da queda de Tróia, alguns dos habitantes fugiram em barcos que encontraram e, depois de serem arrastados pelos ventos até às costas da Etrúria, acabaram por aportar junto do rio Tibre. ${ }^{2}$ 2. As suas mulheres, porém, estavam já esgotadas e sem vontade de se fazerem novamente ao mar, pelo que uma delas, chamada Roma e que parecia distinguir-se pela nobreza de nascimento e em especial pelo bom senso, fez a sugestão de queimarem as naus. Depois de elas assim procederem, os homens começaram por ficar indignados, mas quando a necessidade os forçou a instalar-se nas faldas do Palatino, em breve se viram numa situação melhor do que tinham esperado, pois comprovaram a excelente qualidade da terra e foram bem acolhidos pelos vizinhos. Por isso, prestaram a

${ }^{1}$ A tese da origem grega da cidade de Roma, que Plutarco trata aqui em poucas linhas, conhece a versão mais amplificada em Dionísio de Halicarnasso (Antiguidades Romanas, 1.9.2 e 17-21). A natureza helénica dos Pelasgos é sublinhada com a explicação do nome de Roma a partir do termo grego rhome ('força'), que caracterizaria em particular os Romanos no campo de batalha.

${ }^{2} \mathrm{O}$ próprio Plutarco se refere a esta tradição mais duas vezes ( $S_{0}$ bre a Virtude das Mulheres, 243e-244a; Questóes Romanas, 265b-c). 
devida homenagem a Roma e pela mesma razão deram à cidade o nome dela. 3. Conta-se que daqui deriva o costume de as mulheres cumprimentarem os parentes e familiares do sexo masculino com um beijo na boca. $\mathrm{Na}$ verdade, depois de haverem lançado fogo aos barcos, foi assim que acolheram e acarinharam os maridos, enquanto lhes pediam, entre súplicas, para abandonarem o ressentimento.

2. 1. Na opiniáo de outros, a Roma que deu o nome à cidade era filha de Ítalo e de Leucária (ou, segundo outra versão, de Télefo, filho de Hércules), tendo-se casado com Eneias (ou com Ascânio, filho de Eneias). Há ainda os que sustentam que a cidade foi fundada por Romano, filho de Ulisses e de Circe, ou então por Romo, filho de Hemácion, enviado de Tróia por Diomedes, ou ainda por Rómis, soberano dos Latinos, depois de ter dominado os Etruscos, que da Tessália haviam passado para a Lídia e da Lídia para a Itália. ${ }^{3}$ 2. No entanto, nem mesmo os que, seguindo a tradição mais exacta, reconhecem em Rómulo o epónimo da cidade estão de acordo relativamente à sua genealogia. De facto, uns consideram-no filho de Eneias e de Dexítea, filha de Forbas, e acham que teria

${ }^{3}$ Estas várias hipóteses sobre as origens de Roma, que exploram diferentes conexóes com outros povos, mostram como a questão era controversa já entre os antigos, mas têm em comum o aspecto de procurarem explicar o nome da cidade a partir de um ancestral ilustre. O facto de Plutarco se concentrar em seguida na figura de Rómulo mostra que era esta a versão que colhia maior aceitação, se bem que também estivesse sujeita a disputa acalorada. 
vindo para Itália ainda criança, em companhia do irmão, Romo. Ora, todos os restantes barcos teriam sido destruídos pela forte correnteza do rio, enquanto aquele onde seguiam as crianças se encaminhara suavemente para um banco de areia na margem, salvando-se contra todas as expectativas, pelo que se deu a esse local o nome de Roma. 3. Outros sustentam que Roma, filha da troiana acima referida, se casou com Latino, filho de Telémaco, e dele teve Rómulo. Outros dizem ainda que Emília, filha de Eneias e de Lavínia, o gerou depois de unir-se a Marte. ${ }^{4} 4$. Há também os que tecem a propósito do nascimento dele um relato absolutamente fabuloso. Desta forma, Tarquécio, soberano dos Albanos, pessoa de uma injustiça e crueldade extremas, teria presenciado em casa uma visão fantástica: de facto, ergueu -se no interior da residência um falo e aí permaneceu erecto durante vários dias. Ora havia na Etrúria um oráculo de Tétis, o qual deu a Tarquécio a indicação de que uma virgem se deveria unir àquele espectro, pois dela iria nascer uma criança muito ilustre, que se distinguiria pelo valor, fortuna e força (rhome). 5. Ora Tarquécio falou do oráculo a uma das filhas e ordenou-lhe que se unisse ao falo. Ela, porém, considerou tal coisa indigna

${ }^{4}$ Plutarco está a escrever em grego sobre realidades romanas, pelo que, ao referir-se a divindades latinas, usa o termo grego correspondente. No entanto e para evitar confusóes ao leitor, demos na tradução o equivalente romano: assim acontece com Marte (Ares), Vesta (Héstia), Neptuno (Poséidon), Júpiter (Zeus), Juno (Hera), Ceres (Deméter), Vulcano (Hefestos), e ainda com o herói Hércules (Héracles). Só não adoptámos esta prática nos momentos em que o biógrafo invoca directamente o nome de Zeus, pois aí deve manter-se a versão grega. 
de si e enviou antes uma escrava. Ao tomar conhecimento do sucedido, Tarquécio acolheu muito mal a afronta e condenou ambas à morte. No entanto, Vesta apareceu -lhe em sonhos e proibiu aquele homicídio, ordenando às jovens que tecessem uma tela, com a promessa de que as daria em casamento, assim que terminassem a tarefa. 6. Portanto, estas iam tecendo durante o dia, mas à noite outras, seguindo instruçôes de Tarquécio, desfaziam a peça. Quando a serva que se tinha unido ao falo deu à luz dois gémeos, Tarquécio entregou-os a certo Terácio, com ordens para matar as crianças. 7 . Ele, porém, deixou-as abandonadas junto à margem do rio. Então, uma loba começou a vir ter com os gémeos para lhes dar de mamar, enquanto aves de todo o tipo traziam bocados de alimento e os depositavam na boca dos meninos, até que um pastor se apercebeu da situação (para grande maravilha sua!), teve a coragem de se aproximar e os levou para casa. 8. Foi, portanto, desta forma que conseguiram salvar-se e, depois de crescerem, atacaram Tarquécio e conseguiram vencê-lo. De facto, é esta a versão de certo Promátion, que compôs uma História da Itália. ${ }^{5}$

3. 1. Ainda assim, o relato mais digno de confiança, mais atestado e com maior autoridade foi publicado em primeiro lugar entre os Gregos por Díocles de

${ }^{5}$ Autor conhecido apenas por esta referência em Plutarco, pelo que não há outros elementos externos que permitam uma datação da obra em questão, que o biógrafo parecer ter, de resto, em muito má conta. 
Peparetos, que em boa parte dos casos é seguido também por Fábio Pictor. ${ }^{6}$ Ainda assim, também relativamente a estes pormenores há outras variantes, mas as linhas essenciais são as que passarei a narrar. 2. Entre os descendentes de Eneias que reinaram em Alba, a sucessão acabou por recair em dois irmãos, Numitor e Amúlio. Ora Amúlio dividiu a totalidade da herança em dois lotes, colocando num deles o reino e no outro a riqueza e o ouro que vieram de Tróia; Numitor optou pelo reino. 3. Obtida assim a riqueza, Amúlio tornou-se, graças a ela, mais forte do que Numitor e pôde facilmente usurpar-lhe o trono. Receoso, no entanto, de que a filha de Numitor viesse a ter filhos, levou-a a consagrar-se a Vesta, obrigando-a assim a ficar para sempre solteira e donzela. Uns chamam-lhe Ília, outros Reia, outros ainda Sílvia. 4. Descobriu-se, não muito tempo depois, que se encontrava grávida, contra os ditames estabelecidos para as Vestais, mas Anto, a filha do rei, conseguiu que náo sofresse a pena capital, depois de haver suplicado ao pai, sendo antes mantida em reclusão e isolamento, de forma a que o momento do parto não passasse despercebido a Amúlio. Deu pois à luz dois rapazes, que se distinguiam pelo tamanho e pela beleza. 5. Por este motivo, Amúlio ficou ainda mais receoso e ordenou a um servo que pegasse nas crianças e as levasse dali para fora. Segundo alguns, o nome dele era Fáustulo; outros,

${ }^{6}$ As referências a Díocles e a Fábio Pictor, embora muito discutidas, por causa do problema da antiguidade e cronologia relativa dos dois autores, quererão dizer apenas que Díocles publicou um relato em grego sobre a fundação de Roma, com a versão considerada mais fiel, e que Fábio Pictor a terá seguido. 
porém, defendem que Fáustulo seria não este servo mas antes a pessoa que os acolheu. Colocou, portanto, os bebés numa cesta e desceu até junto do rio, com intenção de lançá-los à água, mas ao constatar que a corrente era alterosa e muito forte, teve medo de aproximar-se em demasia e acabou por abandonar a cesta junto da margem, afastando-se em seguida. 6. Ao inundar as margens, a corrente do rio arrastou docemente a cesta a boiar e transportou-a até um lugar atapetado de erva, a que agora se dá o nome de Cérmalo, embora antigamente se chamasse Gérmalo, segundo parece, pelo facto de os irmáos se denominarem pelo termo 'germanos'.

4. 1. Nas imediaçóes, havia uma figueira-brava que designavam por Ruminal, seja por causa do nome de Rómulo, conforme pensa a maioria, seja por os rebanhos se deterem naquele local a ruminar, aproveitando a sombra para fazer uma sesta, seja ainda e mais provavelmente por as crianças lá terem sido amamentadas. De facto, os antigos chamavam ruma ao mamilo e há mesmo certa deusa, apelidada Rumina, que, segundo parece, zela pelo crescimento das crianças, e à qual se fazem sacrifícios e libações sobre as vítimas não com vinho, mas antes com leite. 2. Contam, portanto, que a loba vinha amamentar os bebés debaixo da figueira e que um picanço ajudava também a dar-lhes alimento e protecção. Ora acontece que estes animais são consagrados a Marte, dando-se o caso de os Latinos adorarem e honrarem em especial o picanço. Por este motivo, não foi difícil acreditar na progenitora, quando ela afirmou 
que as crianças haviam sido geradas por Marte. 3. No entanto, conta-se também que ela teria sido induzida em erro ao proceder desta forma, pois fora Amúlio quem a havia desflorado, ao aparecer-lhe revestido de armas e ao violentá-la. Todavia, outros pensam que foi a própria ambiguidade do nome da ama que permitiu transformar o relato numa fábula. 4. Na verdade, os Latinos usam o mesmo termo lupae não só para designar as lobas, mas também para se referirem às prostitutas: ora a esposa de Fáustulo seria uma dessas mulheres chamada Aca Larência - e teria sido ela a amamentar os meninos. 5. Em todo o caso, os Romanos também lhe dedicam sacrifícios e, no mês de Abril, o sacerdote de Marte faz libaçóes em sua honra, num festival chamado Larentalia.

5. 1. Todavia, prestam honras igualmente a uma outra Larência, pelo seguinte motivo: o guardiáo do templo de Hércules, que andava insatisfeito devido à falta de ocupação, segundo consta, terá proposto ao deus que jogassem aos dados, acordando que, se fosse ele a ganhar, receberia da divindade um qualquer favor, e que se o deus levasse a melhor ganharia um lauto banquete e uma bonita mulher para com ela se deitar. 2. Firmado este pacto, lançou primeiro os dados para o deus e em seguida para si mesmo, acabando por perder. Desejoso de cumprir a palavra e de respeitar os termos acordados, preparou um manjar para a divindade e contratou os serviços de Larência, que era uma bela mulher e não se dedicava abertamente à prostituição. Serviu-lhe 
a refeição no templo, onde havia disposto um leito e, depois do banquete, fechou-a no interior, para o deus a possuir. 3. E diz-se que a divindade se encontrou de facto com a mulher, ordenando-lhe para ir logo pela manhã ao Fórum, abraçar o primeiro homem que consigo viesse ter e dele fazer seu amante. Veio então ao seu encontro um dos cidadáos, já avançado em idade e dono de uma fortuna considerável, sem filhos e sem esposa com quem vivesse, de nome Tarrúcio. Este levou Larência para casa, dedicou-lhe o seu amor e, depois de morrer, fê-la herdeira de numerosas e boas propriedades, cuja maior parte ela doou ao povo por testamento. 4. Conta-se que, uma vez já famosa e considerada até protegida pelo deus, ela desapareceu no mesmo local onde aquela primeira Larência fora sepultada. Agora, o sítio é conhecido como Velabro, pois como o rio galgava as margens com frequência, tinham de atravessar de barca esta zona em direcçáo ao fórum, e a palavra deles para 'barca de transporte' é velatura. 5. Outros, porém, sustentam que os patrocinadores de espectáculos mandam cobrir com um teláo a estrada que vai desde o fórum até ao hipódromo, a qual começa neste ponto; ora a palavra latina para 'telão' é velum. É por estes motivos que os Romanos tributam honrarias à segunda Larência.

6. 1. Fáustulo, o porqueiro de Amúlio, tinha levado os bebés consigo, às escondidas de todos; ou então, conforme afirmam alguns, com maior probabilidade, Numitor estaria a par da situação e ajudava em segredo a manter quem se encarregara de tomar conta 
deles. 2. Diz-se ainda que as crianças foram levadas para Gábios, a fim de aprenderem as letras e outras matérias que convêm a pessoas de bom nascimento. Contam que lhes deram o nome de Rómulo e Remo a partir do 'mamilo', 7 pois tinham sido vistos a mamar na loba. 3 . Além disso, desde a mais tenra idade, a nobreza do seu físico deixava logo transparecer a verdadeira natureza que possuíam, pois eram de boa estatura e belos. Depois de crescerem, mostravam-se ambos corajosos e viris, exibindo um espírito disposto a enfrentar os perigos que surgissem e uma audácia a toda a prova. Rómulo, porém, parecia usar melhor o discernimento e a intuição política, pois no relacionamento com os vizinhos, a propósito de problemas com os prados e a caça, dava a impressão de possuir um espírito mais disposto por natureza a mandar do que a obedecer. 4. Por esta razão, eles eram bem vistos pelos companheiros de servidão e pelos mais humildes, ao mesmo tempo que desprezavam os intendentes, os emissários do rei e os chefes dos pastores (pois estes náo lhes eram superiores em valor), náo se preocupando com o facto de suscitarem ameaças e fúrias. 5. Dedicavam-se ainda a actividades e passatempos próprios de pessoas livres e não consideravam coisa enobrecedora a indolência e a falta de canseiras, mas antes o exercício físico, a caça, as corridas, o pôr em fuga piratas, capturar ladróes e livrar da violência os injustiçados. Por estes motivos, atraíam grande fama.

${ }^{7}$ Em latim, ruma; cf. supra 4.1. 
7. 1. Certa vez, gerou-se uma disputa entre os pastores de Numitor e os de Amúlio. Parte do rebanho deste último foi desviada, mas os dois irmãos não se ficaram com a ofensa, antes foram no encalço dos ladrôes, puseram-nos em fuga e recuperaram a maioria das reses. Náo fizeram grande caso da ira de Numitor, optando antes por reunir e acolher muitos indigentes e escravos, aos quais deram ânimo, alimentando as raízes do sentimento de revolta. ${ }^{8}$ 2. Mas numa altura em que Rómulo se apartou a fim de celebrar um sacrifício (pois gostava dos ritos sacrificiais e era dotado para a adivinhação), os pastores de Numitor encontraram Remo, que seguia com um punhado de companheiros, e pelejaram-se entre si. Embora houvesse golpes e feridos de ambos os lados, os homens de Numitor levaram a melhor e capturaram Remo com vida. 3. Foi então conduzido à presença de Numitor e acusado, mas este não o puniu, por receio do irmão, que era muito severo, optando por ir ter com Amúlio a fim de solicitar justiça, uma vez que era seu irmão e havia sido injuriado por servos dele, que era o rei. 4. Uma vez que os habitantes de Alba partilhavam a mesma indignação e achavam que

${ }^{8}$ A par da modesta existência pastoril e da contrastante apetência por uma educação aristocrática à maneira grega, junta-se agora um terceiro elemento, que também implica algumas contradiçóes: o facto de os gémeos reunirem à sua volta um grupo de servos e marginais com intuitos potencialmente revoltosos, quando eles mesmos haviam sido apresentados como defensores da ordem. Em todo o caso, esta imagem de uma juventude violenta - mas indiciadora da inclinaçáo para realizar grande feitos - é a que mais se aproxima de outros relatos de jovens heróis ou de futuros soberanos. 
ele havia sofrido um agravo indigno da sua condição, Amúlio viu-se forçado a entregar Remo a Numitor, para dele fazer o que entendesse. 5. Este levou-o consigo e, mal chegou a casa, ficou admirado com o aspecto físico do jovem, pois a todos suplantava em estatura e força. Notava-lhe ainda estampada na cara a confiança e ousadia de um espírito indómito e impassível diante dos perigos presentes; os seus feitos e empresas, de que ouvira já falar, correspondiam à imagem que tinha diante dos olhos. Porém, o mais importante - segundo parece, por intervenção de alguma divindade que estaria presente e dava impulso ao começo de grandes acontecimentos - foi o facto de Numitor, movido pelo pressentimento e pela acaso da verdade, lhe perguntar quem era e em que circunstâncias nascera. A doçura da voz e o olhar prazenteiro inspiraram no jovem arrojo e esperança. 6 . Confiante, respondeu pois nestes modos: «Não te irei esconder nada; na verdade, pareces mais digno de ser rei do que Amúlio, pois escutas e interrogas antes de punir, enquanto ele entrega as pessoas mesmo sem julgamento. No início, nós julgávamos (eu e o meu irmão gémeo) ser filhos de Fáustulo e Larência, servos do rei. Mas depois de sermos acusados e sujeitos a calúnias diante de ti, e com a nossa vida em jogo, escutámos imensas coisas a nosso respeito: se possuem ou não fundamento, é o que irá decidir - ao que parece - a presente aflição. 7 . Contam, na verdade, que o nosso nascimento está envolvido em mistério, além de que a maneira como nos alimentaram e mantiveram é ainda mais estranha para uns recém-nascidos: na realidade, tinham-nos lançado 
às aves e às feras e acabámos sendo alimentados por elas, com o leite de uma loba e as migalhas de um picanço, depois de andarmos à deriva numa cesta, arrastados pela correnteza do rio. 8. Esta cesta existe ainda e foi conservada; sobre os seus aros de bronze encontravam-se gravadas letras agora quase apagadas, mas que poderiam servir, mais tarde, de inúteis sinais de reconhecimento para os nossos pais, se entretanto morrêssemos.» 9. Quanto a Numitor, ao escutar estas palavras e conjecturando sobre o tempo decorrido a partir da aparência do jovem, não deixou fugir a esperança que lhe assaltava o espírito; antes meditava na forma como poderia encontrar-se em segredo com a filha para com ela trocar impressóes sobre estes problemas. De facto, ela continuava a ser fortemente vigiada.

8. 1. Ora Fáustulo, ao saber da captura e entrega de Remo, pensou que seria conveniente Rómulo acudir em sua ajuda, depois de o esclarecer claramente sobre as circunstâncias do nascimento. Antes disso, havia apenas sugerido e insinuado o bastante para eles não se terem por pessoas de baixa condição. Ele mesmo foi ter com Numitor, levando consigo a cesta, cheio de pressa e de receio por causa das circunstâncias. 2. Levantou, contudo, suspeitas nos guardas do rei que se encontravam junto das portas e, ao ver-se alvo de desconfiança e de perguntas, pôs-se a tremer e não foi capaz de esconder a cesta que trazia embrulhada no manto. Por sorte, dava-se o caso de encontrar-se entre os guardas um dos homens que tinham apanhado as crianças para lançá-las 
ao rio e haviam acompanhado a sua exposição. 3. Portanto, ao dar com os olhos na cesta, ele reconheceu-a pelo formato e pela inscrição, logo intuiu o que se passava e, sem mais detença, pôs o rei ao corrente da situação, trazendo o homem à sua presença para o submeterem a interrogatório. 4. Depois de se ver sujeito a muitas e penosas torturas, Fáustulo não conseguiu resistir e guardar o segredo para si, mas também não lograram forçá-lo a revelar tudo. De facto, confirmou que as crianças se tinham salvado, mas disse que se dedicavam à pastorícia longe de Alba. Aliás ele vinha em pessoa trazer a cesta a Ília, que muitas vezes desejara ardentemente vê-la e tocá-la, para reforçar a esperança no destino dos filhos. 5. Ora precisamente a sensação que experimentam as pessoas ansiosas e que agem movidas pelo receio ou pela ira, também Amúlio a experimentou. E porque estava noutro ponto da cidade, mandou a toda a pressa um homem, amigo de Numitor e uma excelente pessoa, com instruçôes para se informar junto do irmão sobre se lhe teria chegado notícia de que as crianças haviam sobrevivido. 6. Portanto, o homem chegou a tempo de ver ainda Remo nos braços de Numitor, entre manifestaçóes de afecto, e logo a sua esperança se volveu em vigorosa certeza. Exortou-os a passarem rapidamente à acção e, além disso, pôs-se do seu lado, pronto a colaborar com eles. 7. As circunstâncias não permitiam mais delongas, mesmo que o tivessem desejado. De facto, Rómulo já se encontrava nas redondezas e ao seu encontro vinham náo poucos cidadãos, fosse por ódio fosse por receio de Amúlio. Para mais, trazia consigo 
uma grande força de homens, organizados em grupos de cem. À cabeça de cada um dos grupos vinha um indivíduo, erguendo uma haste encimada por um braçado de feno e de ramos, a que os Latinos dão o nome de manipulus; por este motivo, ainda agora, nos seus exércitos, chamam a estas pessoas manipulares. ${ }^{9} 8$. Enquanto Remo procurava sublevar os que se encontravam no interior da cidade, Rómulo avançava a partir de fora. $\mathrm{O}$ tirano não conseguiu tomar qualquer medida nem zelar pela própria salvação, por incapacidade e perturbação, pelo que acabou sendo capturado e morto. 9. A maior parte destes eventos é narrada por Fábio e por Díocles de Peparetos, o qual - segundo consta - havia sido o primeiro a publicar uma Fundação de Roma; ${ }^{10}$ alguns, porém, mostram-se renitentes, por causa da presença de elementos farsescos e fictícios. Em todo o caso, não se justifica a desconfiança, ao constatarmos de que tipo de obras foi artífice a fortuna e ao enumerarmos as façanhas dos Romanos: de facto, não teriam chegado a uma tamanha força, se não houvessem tido uma origem divina, magnífica e extraordinária.

9. 1. Com a morte de Amúlio e o restabelecimento da ordem, os gémeos não queriam permanecer em

9 A explicação etimológica do termo 'manípulo' deriva, provavelmente, da tradição antiquária, mas a sua aplicação a um período tão recuado é pura especulação sem fundamento histórico. Para mais, a interpretação de um manipulus como equivalente a uma centúria está errada, pois comportava, na verdade, duzentos homens (ou duas centúrias).

${ }^{10}$ Sobre estes dois historiadores, vide supra nota a 3.1. 
Alba sem reinar, nem desejavam fazê-lo enquanto o avô materno fosse vivo. Por isso, uma vez devolvida a soberania a Numitor e prestadas as honras devidas à mãe, decidiram tratar da vida por conta própria, fundando uma cidade na regiáo onde tinham começado por ser criados. Esta é, de facto, a explicação mais provável. 2. Mas seria igualmente uma opção necessária, pois escravos e fugitivos tinham-se juntado a eles em grande número, pelo que ou se dispersavam e eram inteiramente aniquilados ou passavam a viver com eles noutras paragens. $\mathrm{Na}$ verdade, os habitantes de Alba não achavam conveniente misturar a população com os fugitivos, nem acolhê-los como cidadãos. Mostra-o, antes de mais, o rapto das mulheres, devido não à insolência ou audácia, mas antes à necessidade, motivada pela falta de casamentos espontâneos; na verdade, a seguir ao rapto, respeitaram-nas para além do usual. ${ }^{11} 3$. Depois, uma vez lançadas as primeiras fundaçóes da cidade, estabeleceram um santuário de acolhimento para os foragidos, dedicado ao deu Asilo: recebiam toda a gente e não entregavam nem o escravo aos senhores, nem o devedor aos credores, nem o homicida aos magistrados, pois argumentavam que um oráculo de Delfos os autorizava a garantir asilo a toda a gente, de tal forma que a cidade rapidamente se encheu de pessoas, quando, ao que se diz, os lares originários não seriam mais de mil. Mas disso falarei depois. 4. Ora quando se preparavam para criar uma única cidade, surgiu entre eles um diferendo relativamente

${ }^{11}$ Refere-se ao conhecido episódio do rapto das Sabinas, abordado a partir do capítulo 14 . 
ao local. De facto, Rómulo fundou a chamada Roma Quadrada (pois tinha uma forma quadrangular) e queria transformar esse local numa cidade; Remo, porém, escolheu antes uma zona sólida no Aventino, à qual deu o nome de Remória e hoje é conhecida por Rignário. ${ }^{12} 5$. Acordaram entre si resolver a disputa através da observação das aves de bom augúrio. Tomaram entáo assento em lugares distintos e conta-se que Remo terá avistado seis abutres e Rómulo o dobro desse número. Alguns defendem que Remo avistou realmente as aves e que Rómulo mentiu, pois só ao chegar junto de Remo teria visto os doze abutres. É por este motivo que, ainda hoje, quando os Romanos pretendem consultar o voo das aves, observam sobretudo os abutres. 6. Herodoro Pôntico conta que Hércules também ficava contente, se lhe aparecesse um abutre antes de iniciar um trabalho. ${ }^{13} \mathrm{Na}$ verdade, é o menos prejudicial de todos os seres vivos, dado que náo faz mal algum ao que os homens semeiam, plantam ou apascentam, pois alimenta-se de corpos já mortos; não mata nem prejudica nada que tenha vida e nem sequer se aproxima do cadáver de outras aves, pois são da mesma espécie. Contudo, as águias, corujas e falcôes atacam

${ }^{12}$ A designação de Roma quadrata ocorre com frequência para designar, sobretudo, uma parte do monte Palatino em sentido restrito, portanto um local distinto da restante cidade. Plutarco parece aplicar analogicamente o termo Remoria (ou Remorium) para referir-se também a uma parcela do Aventino.

${ }^{13}$ Herodoro Pôntico foi um autor que esteve activo à volta do ano 400 a.C.; esta referência à sua obra justifica-se pelo facto de ele ter abordado profundamente o mito de Hércules. 
os próprios semelhantes enquanto estão vivos e matam -nos. De facto, tal como afirmava Ésquilo: ${ }^{14}$

"Como pode ser pura uma ave que se alimenta da carne de outra ave?»

7. Para mais, os restantes pássaros passeiam-se, por assim dizer, debaixo dos nossos olhos e deixam-se ver todo o tempo; o abutre, porém, raramente aparece e sabemos que não é nada fácil encontrar as suas crias. Por isso, alguns aventaram a estranha suposição de eles virem ter connosco de longe, de um qualquer outro país, e ainda assim raramente e de forma irregular, de maneira que os adivinhos pensam que isso acontece não por causas naturais ou por espontânea vontade, mas antes por uma divindade os enviar.

10. 1. Quando Remo tomou conhecimento do ludíbrio, ficou enfurecido e, à medida que Rómulo ia traçando o sulco onde implantaria a cintura de muralhas, punha-se a desdenhar dos trabalhos e a criar entraves. 2. Por último, ao saltar a vala foi atingido (segundo uns por Rómulo e segundo outros por Célere, um dos seus companheiros) e ali mesmo tombou morto. ${ }^{15} \mathrm{Nes}$ sa escaramuça, caíram também Fáustulo e Plistino, o qual - segundo se conta - era irmão de Fáustulo e tinha

${ }^{14}$ Suplicantes, 226.

$15 \mathrm{O}$ engano e morte de Remo são dois dos aspectos menos edificantes das lendas fundacionais e, além de ajudarem a caracterizar Rómulo (e, por extensão, o próprio povo romano), simbolizam também o carácter inviolável das muralhas. 
ajudado a criar Rómulo e Remo. 3. Quanto a Célere, fugiu para a Etrúria e, depois dele, os Romanos passaram a designar por celeres as pessoas rápidas e cortantes. Chamaram Célere também a Quinto Metelo, surpreendidos pela sua rapidez de organização, pois conseguiu preparar em poucos dias um combate de gladiadores, por ocasiáo da morte do pai. ${ }^{16}$

11. 1. Quanto a Rómulo, assim que, em Remória, deu sepultura tanto a Remo como às pessoas que os tinham criado a ambos, tratou da fundação da cidade, depois de mandar vir da Etrúria homens que acompanhassem todos os pormenores, de acordo com certas normas e textos sagrados, e os instruíssem, como acontece na iniciação mistérica. 2. Escavou um fosso em forma circular junto da zona onde fica agora o Comício, para nele serem depositadas as primícias de tudo quanto era considerado bom segundo o costume ou necessário por natureza. Por fim, cada pessoa trouxe uma pequena porçáo de terra do seu país de origem e atirou-a para o buraco, misturando-a com as restantes coisas. Designam este fosso pelo mesmo nome que dão ao céu: mundus. ${ }^{17}$ Em seguida, tomando este círculo como o ponto central, desenharam à volta os limites de toda a cidade.

${ }^{16}$ Quinto Cecílio Metelo Célere foi um tribuno da plebe em 90 a.C. Célere é apresentado aqui como a pessoa de cujo nome derivaria o termo para designar alguém que é rápido. Cf. infra 26.2.

${ }^{17} \mathrm{O}$ mundus representa o centro augural da cidade, cujo ritual de fundação se baseia, essencialmente, em Varrão (Sobre a Língua Latina, 5.143), combinado embora com informação proveniente de outras fontes. 
3. O fundador prendeu uma relha de bronze no arado, ao qual aparelhou um boi e uma vaca, e pôs-se a fazer ele mesmo um sulco profundo ao longo dos limites da cidade. A tarefa de quem vinha atrás dele consistia em deitar para dentro do perímetro os torróes que o arado fazia saltar para fora, de modo a que nenhum ficasse no exterior. 4. Foi, portanto, com este traçado que delimitaram a muralha e atribuíram-lhe a designação sincopada de pomerium, ou seja, 'o que está por detrás ou junto do muro'. Quando pretendiam abrir uma porta, tiravam a relha do solo, levantando o arado, e deixavam um intervalo. 5. Daqui deriva a convicção de considerar sagrada toda a muralha, com excepção das portas, pois se as julgassem também sagradas não seria possível deixar entrar e sair, sem escrúpulo religioso, tanto as coisas necessárias como as impuras. ${ }^{18}$

12. 1. Ora os autores estáo de acordo em que a fundação se deu no décimo primeiro dia antes das calendas de Maio, data festejada pelos Romanos como sendo o nascimento da pátria. Ao que se conta, no início não se sacrificava nenhum ser vivo, pois achavam que a festa dedicada ao nascimento da pátria deveria manter-se pura e sem derramamento de sangue. 2. Em todo o caso, já antes da fundação se celebrava entre eles, naquele mesmo dia, uma festa pastoril, chamada Parilia. ${ }^{19} \mathrm{Na}$ actualidade, porém, o começo dos meses ro-

${ }^{18}$ Nas Questóes Romanas (271), Plutarco esclarece que as 'coisas impuras' eram os cadáveres.

${ }^{19}$ As Parílias ou Palílias eram festejadas no dia 21 de Abril. 
manos náo corresponde ao dos gregos. Sustenta-se que Rómulo fundou a cidade exactamente no trigésimo dia e que a conjugação, nessa mesma altura, da lua com o sol provocou um eclipse, que eles julgam equivaler ao observado pelo poeta épico Antímaco de Teos, ocorrido no terceiro ano da sexta olimpíada. ${ }^{20} 3$. Nos tempos do sábio Varrão - a pessoa mais erudita entre os Romanos no que a conhecimentos históricos diz respeito -, vivia também o seu amigo Tarúcio, estudioso igualmente sábio e astrónomo, que se interessava pela astrologia por simples especulação teórica, embora fosse considerado um especialista na matéria. 4. Varráo lançou-lhe o desafio de calcular o dia e a hora do nascimento de Rómulo, fazendo o cálculo a partir do influxo dos astros sobre determinada pessoa, da mesma forma como se demonstra a solução para problemas de geometria. Segundo ele, de facto, o procedimento seria o mesmo: tomar a data do nascimento de uma pessoa e prever-lhe a vida ou então, conhecendo-lhe a vida, ir em busca do seu nascimento. 5. Tarúcio cumpriu, por conseguinte, o que lhe fora solicitado: depois de analisar as vivências e feitos de Rómulo, de ligar entre si a duração da vida, a forma como pereceu e outros elementos semelhantes,

${ }^{20}$ A ligação da fundação da cidade à ocorrência de fenómenos astrológicos invulgares visa reforçar o carácter igualmente excepcional de Roma. A referência a Antímaco remete para a data de 754/3 (o ano ático fixado por Varrão para a fundação de Roma), mas nesse período náo houve eclipses da lua visíveis na zona do Mediterrâneo, pelo que talvez o poeta aludisse antes ao eclipse que ocorrera uns anos antes ( 4 de Abril de 778 a.C.) e fora visível também em Teos. 
foi de maneira bastante confiante e audaz que declarou que Rómulo havia sido concebido no ventre da mãe no primeiro ano da segunda olimpíada, ${ }^{21}$ no dia vinte e três do mês Choiak no calendário egípcio, na hora terceira, durante um eclipse total do sol, e ainda que tinha vindo ao mundo no vigésimo primeiro dia do mês de Thouth, ao nascer do sol. 6. Roma teria sido fundada por ele ao nono dia do mês Pharmouthi, entre a segunda e a terceira hora. De facto, os astrólogos crêem que a fortuna de uma cidade, tal como a de uma pessoa, tem um tempo fatídico, que pode ser calculado a partir da posição dos astros no dia do nascimento. Em todo o caso, estas especulaçôes e outras da mesma natureza poderão talvez atrair leitores pela estranheza e extravagância, e não tanto perturbá-los pelo seu carácter fabuloso.

13. 1. Uma vez fundada a cidade, Rómulo começou por dividir o conjunto das pessoas em idade de pegar em armas por contingentes militares. Cada contingente contava com três mil soldados de infantaria e trezentos cavaleiros; foi-lhe dado o nome de legiáo, por os combatentes serem escolhidos entre todos. ${ }^{22}$ 2. Em seguida, considerou os outros habitantes como a massa do povo e a essa multidão atribuiu a designação de populus. ${ }^{23}$ Aos cem de melhor nascimento atribuiu o con-

21772 a.C.

${ }^{22} \mathrm{O}$ termo latino para referir a legião (legio) designava, antes de mais, o processo de recrutamento; a etimologia apresentada por Plutarco está correcta, uma vez que a palavra tem a mesma raiz que legere 'escolher'.

${ }^{23}$ Populus designa, neste contexto, a massa da população livre, 
selho, passando a designá-los por patrícios e por senado o órgão que constituíam. ${ }^{24} 3$. Na verdade, o senado significa exactamente um 'conselho de anciáos' e os seus membros chamavam-se patrícios, devido ao facto - segundo afirmam alguns - de serem pais de filhos legítimos; outros sustentam que é antes por serem capazes de indicar o respectivo pai, coisa que não estavam em condiçóes de fazer muitos dos que começaram por afluir à cidade; outros ainda fazem derivar o termo da instituição do patronato. 4. De facto, era e continua a ser também agora esta a forma como designavam o protector pessoal, convictos de que o nome deriva de certo Pátron, um dos companheiros de Evandro, conhecido por ser uma pessoa solícita e protectora dos mais fracos, cujo nome ficou para designar esta prática. ${ }^{25} 5$. Ainda assim, a razão mais verosímil a sustentar é a seguinte: parecia correcto a Rómulo que os primeiros e mais fortes dos

distinguindo-se, portanto, do corpo armado e da elite senatorial. $\mathrm{Na}$ verdade, esta concepção acusa a influência de concepçóes posteriores, que tendem a identificar o povo com a plebs, pois inicialmente populus deveria englobar o plenário dos cidadáos.

${ }^{24}$ Nas fontes, há uma certa tendência para sustentar que o senado originário comportaria cem membros e para se entender o número de trezentos patres conscripti (à letra, 'os patrícios registados em listagem') como resultado de alargamentos sucessivos. $\mathrm{Na}$ Vida de Numa (2.6), o próprio Plutarco aponta antes o número inicial de cento e cinquenta senadores (talvez como resultado do uso de fontes diversas), enquanto na biografia de Rómulo fala de cem membros, aumentados para o dobro no seguimento do acordo com Tácio (cf. infra 20.1 e 5).

${ }^{25}$ As relaçóes de interdependência entre patrono e cliente ( $p a$ tronus/cliens) constituem um dos traços mais característicos e importantes da sociedade romana, desde a época arcaica. 
cidadãos zelassem, com solicitude e empenho paternais, pela protecção dois mais humildes. Pretendia, ainda, ensinar estes últimos a náo recear os poderosos nem a ficar incomodados com as honrarias deles, mas antes a tratá-los com benevolência e considerá-los como pais, apelidando-os precisamente dessa maneira. 6. Na verdade, mesmo agora, as pessoas de fora chamam chefes aos membros do senado; os próprios Romanos os apelidam de patres conscripti, título com o qual pretendem exprimir o máximo respeito e deferência, não manifestando qualquer inveja em relação a quem usa este nome. De facto, no início designavam-se apenas como patres, mas depois, à medida que se juntaram outros, passaram a chamar-se patres conscripti. 7. Na realidade, através desta designação especial, Rómulo fixava melhor a diferença entre o povo e o senado. Estabeleceu ainda, por outras vias, distinção entre os poderosos e a multidão, ao designar aqueles por patronos (ou seja protectores) e estes por clientes (ou seja dependentes). ${ }^{26}$ Ao mesmo tempo, criou uma espantosa boa disposição de uns em relação aos outros, que constituiu a base de importantes direitos legais. 8. De facto, os patronos eram os intérpretes dos costumes tradicionais, protectores dos clientes sujeitos a julgamento, garantindo-lhes conselho e assistência em todos os assuntos; os clientes, por outro lado, estavam ao serviço deles, não só para prestar honras, mas

${ }^{26}$ Plutarco compara aqui a situação grega e romana, fazendo equivaler prostates a patronus e pelates a cliens. Esta leitura, que encontrou algum eco em estudiosos modernos, é, no entanto, demasiado redutora e simplista, pois a relação pessoal estabelecida entre este par de conceitos é distinta nas duas culturas. 
ainda, no caso de aqueles tombarem na pobreza, para lhes garantir dote às filhas e assumir solidariamente o pagamento de dívidas. Nenhuma lei e magistrado algum podiam obrigar um patrono a testemunhar contra o cliente ou um cliente a depor contra o patrono. 9. Em tempos posteriores, embora se mantivessem as mesmas obrigaçôes mútuas, acabou por ser considerado vergonhoso e ignóbil que os poderosos aceitassem dinheiro dos mais humildes. No entanto, sobre esta questão é já quanto basta.

14. 1. No quarto mês a seguir à fundação, como narra Fábio, ocorreu o ousado rapto das mulheres. Ora alguns sustentam que teria sido Rómulo a provocar à força os Sabinos, pois era por natureza amante da guerra e estava convencido, por influência de alguns oráculos, de que Roma tinha um destino marcado por guerras, que a fariam crescer e a tornariam majestosa. De facto, ele teria raptado não muitas donzelas (somente umas trinta), com a intenção de, através delas, atingir mais depressa a guerra do que o casamento. 2. No entanto, esta leitura não se afigura verosímil. $\mathrm{Na}$ verdade, ele havia constatado que a cidade se tinha enchido rapidamente de estrangeiros, que poucos tinham mulheres e que, na sua maioria, constituíam uma mistura de pessoas sem recursos e de origem obscura, vistas com sobranceria pelos outros e de quem não se esperava grande coesão. E assim, porque alimentava a esperança de que a afronta contra os Sabinos pudesse, de certa maneira, fornecer o pretexto e o impulso para se fundirem em comunidade 
com eles, ao manterem as suas mulheres como reféns, meteu mãos ao projecto da maneira a seguir descrita. ${ }^{27}$ 3. Antes de mais, começou por espalhar a notícia de que havia encontrado um altar dedicado a certa divindade, que se descobrira oculto debaixo da terra. Chamaram Conso a esse deus, o qual, para alguns, seria uma divindade conselheira (na verdade, ainda hoje designam o 'conselho' por consilium e os magistrados supremos por consules, ou seja 'conselheiros'); para outros, seria antes uma estátua equestre de Neptuno. 4. $\mathrm{Na}$ realidade, o altar está situado no meio do hipódromo ${ }^{28}$ e encontra-se coberto por um véu todo o tempo, pois destapam-no apenas quando se disputam provas hípicas. Outros, no entanto, dizem apenas que, tendo a decisão sido tomada em segredo e às ocultas, não seria ilógico que o altar dedicado ao deus também se achasse encoberto debaixo da terra. 5. Uma vez posto à vista, Rómulo fez proclamar que realizaria sobre ele um sacrifício esplêndido, promovendo ainda jogos e um espectáculo solene. Muita gente acorreu ao convite. Aliás, Rómulo em pessoa tomou assento junto dos cidadãos mais ilustres, adornado com um manto de púrpura. $\mathrm{O}$ sinal combinado para dar início à empresa consistia em Rómulo levantar -se, dobrar o manto e voltar depois a colocá-lo. 6. Ora muitos homens havia, armados de espada, que estavam

27 Depois de explicar as motivaçóes que terão justificado o plano de Rómulo (mais políticas do que demográficas), Plutarco descreve a instituição dos Consualia, em combinação com o rapto das Sabinas, onde se nota o motivo popular do entendimento do matrimónio como rapto da esposa.

${ }^{28}$ O Circo Máximo. 
com os olhos postos nele; assim que o sinal foi dado, desembainharam as espadas, lançaram-se aos gritos sobre as filhas dos Sabinos e raptaram-nas; aos varóes, porém, deixaram-nos fugir e ir-se embora. 7. Alguns dizem que foram raptadas apenas trinta donzelas, sendo a partir delas que se deu o nome às tribos; porém, Valério Antias fala em quinhentas e vinte e sete, e Juba em seiscentas e oitenta e três. Um aspecto muito importante abona em defesa de Rómulo: de facto, não tomaram nenhuma mulher casada a não ser Hersília, e esta por engano, o que mostra que eles avançaram para o rapto náo por violência ou injustiça, mas antes para fundirem e juntarem os dois povos - e ainda assim movidos por imperiosas necessidades. 8. Uns dizem que a tal Hersília se casou com Hostílio, um dos cidadãos romanos mais ilustres, outros que ficara como esposa do próprio Rómulo, de quem viria a ter descendência: uma filha chamada Prima, devido à ordem do seu nascimento, e um filho ao qual deu o nome de Aólio, pelo facto de ele haver reunido os cidadãos; outros sustentam que, mais tarde, ficou conhecido por Abílio. Em todo o caso, Zenódoto de Trezena, responsável por esta versão dos acontecimentos, entra em contradição com muitos outros autores. ${ }^{29}$

15. 1. Entre os raptores das raparigas, diz-se que se encontravam alguns de nascimento pouco ilustre que

${ }^{29}$ Zenódoto de Trezena é um autor pouco conhecido, do qual possuímos apenas mais três fragmentos, para além do passo em questão, que sugerem uma abordagem sistemática da história de Roma e de Itália. O estabelecimento da sua cronologia é incerto, embora haja indícios de que deva ser anterior a Varrão. 
teriam conseguido agarrar uma jovem de beleza e porte muito superiores. 2. Ora alguns dos poderosos que se cruzaram com eles tentaram retirá-la das suas mãos, mas estes gritavam que a levavam a Talássio, um homem ainda bastante jovem, mas de reputação e carácter excelentes. Ao ouvirem esta explicação, os outros louvaram e aplaudiram a decisão; alguns voltaram mesmo para trás e acompanharam-nos em sinal de boa vontade e para agradarem a Talássio, cujo nome iam repetindo em alta voz. $^{30}$ 3. Daqui deriva o costume, ainda em uso, de os Romanos invocarem Talássio durante os cantos nupciais, tal como os Gregos invocam Himeneu. De facto, conta-se que o relacionamento de Talássio com a esposa decorreu num clima de boa harmonia. Séxtio Sula de Cartago, pessoa a quem não faltam estudos nem fineza de espírito, disse-me que Rómulo deu este nome como senha para o rapto. ${ }^{31} 4$. Assim, todos gritavam "Talássio" ao levarem uma jovem e, por isso, manteve-se este costume nas núpcias. A maioria dos autores, porém, entre os quais se conta Juba, acha que se trata de um convite e de um incitamento a dedicar-se ao trabalho e a fiar a lá, tal a proximidade que, naquela altura, havia entre

${ }^{30}$ Este pormenor do relato constitui uma das variantes da explicação etiológica do grito nupcial $T(h)$ alassio ou Talasse, que, entre outras interpretaçóes, tem sido relacionado também com os termos gregos thalamos ('tálamo'), talaros ('cesto para a lâ') ou talasia ('trabalho de fiar a lä). A última possibilidade vai ser desenvolvida por Plutarco.

${ }^{31}$ Séxtio Sula era um amigo de Plutarco, com quem privara em Roma, e vem referido repetidas vezes na obra do biógrafo. Plutarco sugere que ele deveria ser especialista em questóes de antiquária e sobretudo uma pessoa de grande cultura. 
os termos gregos e latinos. Se isto não for mentira e se, portanto, os Romanos usavam essa palavra para referirem o trabalho de fiar a lã, tal como nós fazemos, então seria possível encontrar outra explicação ainda mais convincente. 5. De facto, depois de os Sabinos se reconciliarem com os Romanos quanto ao diferendo, firmaram com eles um acordo relativo às mulheres, segundo o qual estas não se ocupariam de nenhuma outra tarefa para os maridos a não ser do trabalho de fiar a lã. Portanto, ainda se usa agora que as pessoas que entregam uma mulher em casamento, ou acompanham o cortejo ou simplesmente assistem à boda, gritem por brincadeira "Talássio", como testemunhas de que a esposa não será obrigada a nenhuma outra canseira a não ser a de fiar a lá. 6. Conservou -se ainda até ao nosso tempo o costume de a noiva não atravessar pelo seu pé a porta do quarto, mas ser antes levada para dentro ao colo, porque no passado as Sabinas entraram em casa à força e não de espontânea vontade. 7 . Alguns afirmam também que o acto de separar os cabelos da noiva com a ponta de uma lança simboliza a circunstância de o primeiro casamento ter ocorrido depois de um combate e envolto em polémica. Sobre este problema, já falei com mais pormenor nas Questóes Romanas. ${ }^{32} \mathrm{~A}$ aventura do rapto ocorreu, portanto, no décimo oitavo dia do mês que se chamava então Sextil e corresponde agora a Agosto, durante o qual se celebra a festa dos Consualia.

${ }^{32}$ Moralia, 285b. Esta informação ajuda a reforçar a ideia de que a prática de remeter para outros trabalhos seus estaria na escrita original de Plutarco, além de mostrar que as Questóes Romanas são anteriores às biografias de Teseu e de Rómulo. 
16. 1. Os Sabinos eram muito numerosos e aguerridos, embora vivessem em povoações desprovidas de muralhas, por acharem que infundiam respeito e nada teriam a recear pelo facto de serem colonos lacedemónios. Em todo o caso, ao verem-se vinculados por reféns tão preciosos e receando ainda pela sorte das filhas, optaram por enviar embaixadores com exigências benevolentes e ponderadas: que Rómulo lhes devolvesse as jovens e desagravasse aquele acto de violência; depois disso, usariam da persuasáo e da legalidade para firmarem entre os dois povos laços de amizade e de boa vizinhança. 2. Rómulo, porém, não devolvia as raparigas e exortava antes os Sabinos a acolherem a união com Roma. Entretanto, uns e outros iam-se alongando em deliberaçóes e em preparativos para a guerra. Todavia, Ácron, rei de Cenina, homem de carácter resoluto e temível em combate, ficou desconfiado a seguir às primeiras bravatas de Rómulo, achando que, depois do procedimento com as mulheres, ele se tornaria um perigo para todos e intolerável, a menos que fosse devidamente punido. Passou, por conseguinte, ao ataque, à cabeça de um poderoso exército, e Rómulo agiu de igual forma. 3. Assim que ficaram à vista e puseram os olhos um no outro, desafiaram-se para um combate singular, enquanto os exércitos de ambos assistiam imóveis, de armas aparelhadas. Então, Rómulo formulou o voto de que, se o vencesse e derrubasse, tomaria as armas do adversário e iria dedicá-las ele mesmo a Júpiter. ${ }^{33}$ Ora

${ }^{33}$ Este relato pretende explicar também a origem do costume de dedicar os spolia opima a Júpiter Ferétrio e, de alguma forma 
não só o dominou e abateu, como ainda pôs em fuga o exército, depois de entrar em combate, e conquistou também a cidade. Mesmo assim, não exerceu violência sobre os prisioneiros, mas ordenou-lhes que derrubassem as suas casas e o seguissem até Roma, onde se tornariam cidadãos com direitos iguais. Em boa verdade, foi esta atitude, mais do que qualquer outra razão, que permitiu a Roma tornar-se grande: conciliar consigo mesma e integrar sempre os povos que ia vencendo. 4. Rómulo, porém, depois de reflectir sobre a maneira como poderia cumprir melhor o voto feito a Júpiter e facultar aos cidadãos um espectáculo agradável, mandou cortar um carvalho colossal no sítio onde o exército estava acampado, deu-lhe a forma de um troféu e suspendeu à volta dele as armas de Ácron, dispostas no devido lugar. Em seguida, envergou o uniforme e cingiu com louro a farta cabeleira. 5. Pegou então no troféu, que mantinha ao alto apoiando-se no ombro direito, e deu início à marcha triunfal, entoando um péan de vitória, acompanhado pelo exército que o seguia revestido de armas e acolhido pelos cidadáos, entre manifestaçóes de satisfação e de espanto. Este cortejo representou, por conseguinte, a origem e o modelo dos triunfos posteriores. 6. O troféu foi dedicado a Júpiter Ferétrio, assim chamado porque os Romanos usam a palavra ferire para dizer 'golpear', e fora esse o voto formulado por Rómulo - ferir e abater o adversário. Segundo Varrão, estes despojos referem-se com o termo 'opimos', pois a noção de

também, a criação do cerimonial do triunfo romano, tal como irá registar o próprio Plutarco. 
abundância designa-se com o vocábulo ops. No entanto, um qualquer autor seria mais preciso se afirmasse que o nome deriva antes da acção realizada: na verdade, um 'feito' designa-se com o termo opus e o comandante que, pelas próprias máos e com denodo, houver abatido o inimigo é que está em condiçôes de consagrar despojos opimos. 7. De resto, apenas a três chefes romanos foi concedida esta honra: em primeiro lugar, a Rómulo, por ter matado Ácron de Cenina; em segundo, a Cornélio Cosso, por haver abatido o etrusco Tolúmnio; por último, a Cláudio Marcelo, por ter vencido o chefe gaulês Britomarto. Na verdade, Cosso e Marcelo celebraram o triunfo montados numa quadriga, transportando pessoalmente os troféus, mas Dionísio está errado quando afirma que Rómulo usou também um carro. 8. Conta-se ainda que Tarquínio, filho de Demarato, foi o primeiro soberano a elevar a cerimónia do triunfo a esta pompa e circunstância; outros, ainda, sustentam que o primeiro a festejar o triunfo sobre um carro teria sido Publícola. As representaçôes de Rómulo que se podem observar em Roma mostram-no todas a levar os troféus a pé.

17. 1. Depois da tomada de Cenina e numa altura em que os restantes Sabinos se encontravam ainda em preparativos, os habitantes de Fidena, Crustumério e Antemna aliaram-se contra os Romanos. ${ }^{34}$ Po-

${ }^{34}$ Fidena, Crustumério e Antemna são as três cidades vizinhas de Roma que, segundo a tradição, Rómulo teria derrotado e que Plutarco apresenta erradamente como sendo também urbes sabinas. 
rém, uma vez travada a batalha, foram também vencidos, não conseguindo impedir que as cidades caíssem nas mãos de Rómulo, o território fosse dividido e eles próprios acabassem deportados para Roma. 2. Em boa verdade, Rómulo distribuiu pelos cidadáos estas terras, mas permitiu que os pais das jovens raptadas mantivessem as respectivas propriedades. Incapazes de suportar tamanha afronta, os restantes Sabinos entregaram o comando a Tácio e marcharam sobre Roma. No entanto, a cidade era de difícil acesso, pois tinha a defendê-la a colina do actual Capitólio, onde se encontrava uma guarnição comandada por Tarpeio - e não pela jovem Tarpeia, conforme sustentam alguns, querendo fazer de Rómulo um simplório. Em todo o caso, Tarpeia, que era filha do comandante, veio a entregar a cidade aos Sabinos, seduzida pelas braceletes de ouro que os vira a usar, pedindo em troca da traição o que eles traziam no braço esquerdo. 3. Tácio aceitou o acordo e, durante a noite, ela abriu uma das portas e deixou entrar os Sabinos. Ora segundo parece, Antígono ${ }^{35}$ não teria sido o único a dizer que apreciava os que eram capazes de trair e que os detestava depois de traírem; nem tampouco César, o qual comentara, a propósito do trácio Remetalces, que era capaz de amar a traiçáo e odiar o traidor. ${ }^{36} \mathrm{Na}$ verdade, este é um sentimento comum en-

35 Trata-se possivelmente de Antígono Gónatas (c. 320-239 a.C.), que reinou sobre a Macedónia, onde desenvolveu uma política de protecção de poetas, filósofos e historiadores, sendo ele próprio também filósofo.

${ }^{36}$ Esta afirmação vem atribuída a Octávio César Augusto, a respeito de Remetalces, rei da Trácia, que, de inicial aliado de Marco 
tre os que necessitam dos serviços de gente baixa, da mesma forma que se pode precisar do veneno ou do fel de certos animais: apreciam-nos quando a necessidade os obriga a tomá-los, mas abominam a sua vileza depois de atingirem os objectivos. 4. Era este, portanto, o sentimento de Tácio relativamente a Tarpeia, ao ordenar aos Sabinos que tivessem em conta os termos do tratado e nada recusassem à jovem do que traziam no braço esquerdo: de resto, foi ele o primeiro a tirar a bracelete e arremessá-la para cima dela, juntamente com o escudo. Todos os outros procederam de igual modo, pelo que Tarpeia, ao ser atingida pelas jóias e coberta pelos escudos, acabou por sucumbir ao seu elevado número e ao peso. 5. Tarpeio teria sido igualmente condenado, ao ver-se acusado de traição por Rómulo, tal como relata Sulpício Galba, segundo Juba. ${ }^{37}$ Não são convincentes outros relatos sobre Tarpeia, segundo os quais ela seria filha de Tácio, o chefe das tropas sabinas, e viveria à força com Rómulo, tendo sido coagida pelo pai a actuar e a ser punida daquela forma. Entre estes autores encontra-se Antígono. ${ }^{38}$ 6. O poeta Símilo mostra-se

António no contexto da guerra civil, se passara para o lado de Octávio.

${ }^{37}$ Sulpício Galba (do qual se conhece apenas um outro fragmento) era avô do imperador Galba e escreveu um relato histórico que Plutarco conhecia através da obra de Juba.

${ }^{38}$ Não é o mesmo Antígono antes referido (17.3), mas provavelmente Antígono de Caristos, que viveu na corte de Átalo I, rei de Pérgamo, na segunda metade do séc. III a.C.; a ser assim, estamos perante um curioso exemplo da reescrita de importantes lendas romanas em ambiente grego, num período ainda bastante recuado. 
totalmente incoerente ao afirmar que Tarpeia entregou o Capitólio não aos Sabinos, mas antes aos Gauleses, depois de apaixonar-se pelo seu rei. Expóe as coisas desta maneira: ${ }^{39}$

Tarpeia, que junto do escarpado Capitólio morava, tornou-se a ruína das muralhas de Roma; por desejar intensamente o leito nupcial do Gaulês, senhor do ceptro, não protegeu a casa paterna.

7. E, pouco depois, a propósito da morte da jovem:

A ela, nem os Béos nem a raça imensa dos Gauleses exultantes a lançaram às correntes do Pó; preferiram antes atirar as armas com as belicosas mãos e sobre a execranda jovem lançar um adorno de morte.

18. 1. Por conseguinte, Tarpeia foi sepultada naquele local e a colina passou a chamar-se Tarpeia, até o rei Tarquínio consagrar o sítio a Júpiter e transladar os restos mortais. E assim desapareceu o nome de Tarpeia, com excepção da rocha existente no Capitólio, à qual ainda hoje chamam Tarpeia e de onde se lançam os malfeitores. 2. O promontório estava, portanto, nas mãos dos Sabinos; então, Rómulo, movido pela ira, desafiou-os para o combate e Tácio aceitou corajosamente, ao constatar que tinham à disposição um refúgio seguro, no caso de serem forçados a recuar. 3. $\mathrm{Na}$

${ }^{39}$ Símilo, cuja identificação continua envolta em dificuldades, é um poeta elegíaco, que viveu possivelmente no séc. III a.C. 
verdade, o lugar que mediava os dois exércitos e onde iriam defrontar-se ficava encaixado entre várias colinas, de modo que parecia oferecer a ambos os lados uma luta árdua e difícil, por causa do carácter acidentado do terreno, onde a fuga e a perseguição estavam confinadas a um espaço estreito. 4. Por casualidade, não muitos dias antes, o rio tinha transvazado as margens, deixando um lodaçal profundo e sem saída na planura onde fica agora o Fórum, o qual nem se notava à primeira vista nem facilmente se evitava, além de ser perigoso e cheio de armadilhas. Era para este ponto que os Sabinos se dirigiam, por ignorância, quando se presenciou um golpe da sorte. 5. De facto, Cúrcio, pessoa notável pela fama e de espírito orgulhoso, avançava a cavalo muito à frente dos restantes, quando o animal caiu num poço fundo. De início, ainda procurou tirá-lo para fora, com açoites e gritos de incitamento, até que, ao ver-se incapaz, abandonou o cavalo e conseguiu salvar-se. 6. À conta dele, este lugar é conhecido ainda hoje como lacus Curtius. Ora depois de contornarem o perigo, os Sabinos envolveram-se num duro combate, que se mantinha indeciso, apesar de muitos tombarem. Entre os mortos encontrava-se Hostílio; ${ }^{40}$ dizem que era o esposo de Hersília e avô do Hostílio que foi rei a seguir a Numa. 7. Entretanto, suscitaram-se em pouco tempo muitas escaramuças, como seria de prever, mas uma - a última - tornou-se particularmente memorável, pois durante

${ }^{40}$ Trata-se de Hosto Hostílio, antepassado da gens Hostilia e do rei Tulo Hostílio, cuja presença nas lendas fundacionais era bastante explorada pelos historiadores deste período inicial da cidade. 
ela Rómulo foi ferido com uma pedra na cabeça e esteve a ponto de desfalecer, abandonando a luta. Entáo, os Romanos recuaram perante os Sabinos e retiraram para o Palatino, depois de se verem acossados na planície. 8. Entrementes, Rómulo recuperara já do golpe e queria retomar as armas, a fim de travar a fuga dos companheiros, a quem exortava, com grandes berros, a permanecer firmes e retomar o combate. Todavia, as vagas de fugitivos rodeavam-no e ninguém tinha coragem para resistir, pelo que ele ergueu as mãos em direcção ao céu e suplicou a Júpiter que detivesse o exército e náo assistisse com indiferença à ruína da causa romana, mas antes restabelecesse o seu ardor. 9. Uma vez terminada a prece, muitos foram assaltados pela vergonha diante do rei e a coragem regressou novamente aos fugitivos. Por conseguinte, começaram por deter-se no lugar onde fica agora o templo de Júpiter Stator, cujo apelido pode ser interpretado como 'o que detém'. E assim, depois de cerrarem fileiras, obrigaram os Sabinos a recuar de novo até ao lugar conhecido presentemente por Régia e até ao templo de Vesta.

19. 1. Uma vez nesse local, enquanto se preparavam para retomar a batalha, apareceu-lhes diante dos olhos uma imagem impressionante de se contemplar e um espectáculo superior a qualquer relato. ${ }^{41} 2$. De facto, as filhas dos Sabinos que haviam sido raptadas

${ }^{41}$ Plutarco vai descrever agora o célebre episódio em que a intervenção das jovens raptadas irá estabelecer a paz e promover a união entre Romanos e Sabinos. 
podiam avistar-se a surgir de todos os lados, lançando gritos e lamentaçóes, por entre armas e cadáveres, como se estivessem possuídas por algum génio divino. Umas dirigiam-se aos maridos e aos pais, outras levavam nos braços os filhos ainda crianças, outras ainda escondiam o rosto com os cabelos desgrenhados, mas todas chamavam, com os nomes mais queridos, ora os Sabinos ora os Romanos. 3. Apiedaram-se, portanto, ambos os lados e afastaram-se, para dar às mulheres espaço entre as fileiras. A comoção alastrou a todos os presentes e um grande lamento surgiu ao vê-las e mais ainda ao escutar-lhes as palavras, que, embora justas e francas, terminavam com súplicas e pedidos. 4. E diziam: «Pois que mal ou aflição vos causámos nós, para termos já sofrido no passado e continuarmos ainda a sofrer tão cruéis desventuras? Raptaram-nos, à força e contra a lei, aqueles a quem agora pertencemos. Mas uma vez raptadas, fomos votadas ao esquecimento por irmãos, pais e familiares, a ponto de o tempo nos ter unido, com os laços mais fortes, aos nossos piores inimigos e de presentemente nos fazer recear pelos que ilegalmente nos forçaram, quando se dirigem para o combate, e de os chorarmos quando perecem na batalha. 5. Pois vocês não vieram atacar os agressores, para lavar a nossa honra enquanto éramos virgens, mas querem agora separar esposas e maridos, mães e filhos. A ajuda que nos vêm dar, pobres de nós, é mais penosa que o esquecimento e abandono do passado. 6. Tal como estes nos deram o seu amor, dêem-nos agora a vossa compaixão! $\mathrm{Na}$ verdade, mesmo que combatam 
por outros motivos, necessário é pôr cobro à refrega, uma vez que, por nosso intermédio, vocês se tornaram sogros, avôs e parentes. 7. E se a guerra for por nossa causa, levem-nos juntamente com os vossos genros e os nossos filhos, devolvam-nos os pais e familiares, não nos privem de maridos e descendência. Nós vos suplicamos: não façam de nós prisioneiras outra vez!» Hersília disse muitas outras coisas deste teor, sendo acompanhada pelas súplicas das restantes, até se celebrarem umas tréguas e os chefes se encontrarem para conversaçóes. 8. Entretanto, as mulheres davam a conhecer os maridos e os filhos aos pais e irmãos, traziam alimento e bebida aos que deles precisassem, cuidavam dos feridos e levavam-nos para casa. Deixavam ainda bem à vista que eram elas as senhoras do lar e que os maridos as tratavam com deferência, procurando respeitá-las com toda a honra e boa disposiçáo. 9. Por estas razóes, fizeram o seguinte acordo: que continuassem a viver com os maridos as mulheres que assim o desejassem e, como já antes se disse, ${ }^{42}$ estivessem dispensadas de todas as tarefas e canseiras para além de fiar a lá; que os Romanos e os Sabinos habitassem em comum a mesma cidade; que a cidade se chamasse Roma, a partir de Rómulo, mas que os Romanos fossem conhecidos por Quirites, a partir da pátria de Tácio; ${ }^{43}$ que reinas-

42 Supra, 15.5 .

${ }^{43}$ Como fundador, Rómulo daria o nome à cidade, enquanto Tito Tácio conseguia que os cidadáos fossem referidos a partir do nome da sua pátria de origem (Cures). Esta distinção, contudo, tem mais a ver com a prática helénica de estabelecer novas colónias com populaçóes mistas do que com a tradição romana. 
sem em conjunto e ambos comandassem o exército. 10. O lugar onde firmaram este acordo chama-se ainda hoje Comício, pois os Romanos usam o termo comire para designar o acto de 'reunir'.

20. 1. A cidade duplicou, assim, a população: uma centena de novos patrícios foi escolhida entre os Sabinos, as legióes passaram a contar com seis mil soldados de infantaria e seiscentos cavaleiros. ${ }^{44} 2$. Instituíram ainda as três tribos e chamaram a uma Ramnenses (a partir de Rómulo), a outra Tatienses (a partir de Tácio) e a outra ainda Lucerenses (a partir do bosque para onde muitos haviam fugido, ao abrigo do direito de asilo, vindo a receber depois a cidadania); de facto, chamam luci aos bosques sagrados. ${ }^{45}$ Que as tribos eram três, mostra-o o próprio nome: de facto, ainda hoje se designam por tribos e os chefes por tribunos. ${ }^{46} 3$. Cada uma das tribos englobava dez cúrias, cuja identificação, segundo alguns, deriva do nome das mulheres sabinas. No entanto, isto parece-me errado, pois muitas têm a denominação de regióes. ${ }^{47} 4$. Em todo o caso, concederam

${ }^{44} \mathrm{~A}$ respeito do número de senadores e do tamanho das legióes, vide supra 13.1-2.

${ }^{45}$ Vide supra 9.3. A criaçáo das tribos romanas era geralmente colocada no período posterior à integração dos Sabinos comandados por Tácio; no entanto, as fontes não são unânimes quanto à nomenclatura e respectiva justificação etimológica.

${ }^{46}$ A explicação é mais necessária na óptica de Plutarco (que escrevia em Grego) do que na do leitor, na medida em que, em Português, é mais evidente a proximidade entre tribus/tribunus e o numeral latino tres.

47 As trinta cúrias representam a mais antiga organização 
às mulheres muitas outras demonstraçóes de respeito, entre as quais podem contar-se as seguintes: ceder-lhes passagem, quando andam pela rua; não dizer nada de indecente na presença de uma senhora, nem se mostrar nu, sob pena de vir a ser acusado junto do tribunal responsável pelos homicídios; permitir aos filhos delas o uso da chamada bulla (por causa do formato), acessório parecido com uma bolha que usam à volta do pescoço, e um vestido bordado a púrpura. 5. Os dois reis não deliberavam à partida logo um com o outro, pois cada um o fazia antes em privado com os seus cem conselheiros e depois reuniam todos em conjunto num só corpo. Tácio morava no local onde fica agora o templo de Moneta; ${ }^{48}$ Rómulo habitava junto das escadas conhecidas por Scalae Caci, que ficam próximas da descida do Palatino a caminho do Circo Máximo. ${ }^{49} 6$. Segundo se conta, foi aí também que brotou o cornizo sagrado. De facto, diz a lenda que Rómulo, a fim de meter à prova a sua força, arremessou do Aventino uma lança feita de madeira de cornizo. A ponta da lança enterrou-se bem fundo, de forma que ninguém teve força bastante para a retirar, embora muitos tentassem. A terra, que era fértil, acabou por cobrir a haste e dela brotaram rebentos, que deram origem a um grosso tronco de cornizo. 7. Os

política romana e, embora fossem tradicionalmente relacionadas com as tribos originárias, estas, ao contrário das primeiras, deixaram poucos traços na linguagem posterior (e concentrados sobretudo no campo militar).

${ }^{48}$ Santuário dedicado a Juno, onde se fabricava a moeda.

49 Trata-se da famosa casa Romuli, situada junto da chamada Roma quadrata e das Scalae Caci, náo longe da casa de Augusto. 
descendentes de Rómulo preservaram e veneraram este arbusto como um dos objectos sagrados mais preciosos, cercando-o com um muro de protecção. Se alguém passasse por lá e o arbusto náo aparentasse estar forte nem verdejante, mas antes a definhar e a morrer, dava imediatamente o alerta em altos brados a quem encontrasse. Logo todos vinham em socorro e gritavam "água", como se de um incêndio se tratasse, ao mesmo tempo que acorriam de todos os lados para o local, com baldes cheios. 8. Segundo consta, Gaio César deu instruçôes para restaurar a escadaria, mas os operários escavaram demasiado as fundaçóes e danificaram irremediavelmente as raízes, pelo que a planta acabou por secar.

21. 1. Ora os Sabinos adoptaram os meses dos Romanos e sobre esta questão escrevi já o bastante, na Vida de Numa. ${ }^{50}$ Deles, Rómulo recebeu os escudos, substituindo o seu armamento e o dos outros Romanos, pois até aí usavam o escudo argivo. ${ }^{51}$ As festividades e sacrifícios foram partilhados uns pelos outros, sem eliminarem os que antes eram celebrados por cada um deles, e instituíram ainda outros novos, entre os quais se contam os Matronalia (celebrados em honra das mulheres por terem posto cobro à guerra) e os Carmentalia. 2. Alguns acham que Carmenta seria uma Parca que presidia ao nascimento dos homens e que, por isso, as

${ }^{50}$ Capítulo 19.

${ }^{51}$ A tradiçãa, seguida por Plutarco, fazia recuar a Rómulo, de forma anacrónica, a substituição dos escudos redondos (à maneira dos soldados de infantaria grega - os hoplitas) pelos escudos oblongos, usados pelos Sabinos. 
mães a veneram; segundo outros, seria antes a esposa do árcade Evandro, uma profetisa inspirada capaz de proferir oráculos em verso, à qual foi dado o apelido de Carmenta (pois eles designam os 'poemas' por Carmina), embora o seu nome real fosse Nicóstrate. 3. Quanto ao nome próprio, há geral acordo, mas alguns explicam o termo Carmenta de maneira mais provável, como sendo uma espécie de 'falta de juízo', devida aos delírios provocados pela possessão divina; de facto, os Latinos usam o termo carere para dizer 'ter falta' e mens para designar o 'juízo'. Relativamente aos Parilia, já antes se falou. ${ }^{52}$ 4. Quanto aos Lupercalia deveriam ser ritos de purificação, a avaliar pela época do ano; de facto, celebram-se nos dias nefastos do mês de Fevereiro (que pode ser interpretado como 'o mês das purificaçóes') e antigamente aqueles dias designavam-se por febrata. $\mathrm{O}$ nome desta festividade em Grego significa 'festa dos lobos' (Lykaia) e, por tal motivo, parece ser muito antiga e remontar ao tempo dos Arcádios que acompanharam Evandro. 5. Seja como for, esta opiniáo é geralmente aceite. Afigura-se provável que o nome derive de loba, pois constatamos que os $\operatorname{Lupercos}^{53}$ iniciam a sua corrida à volta da cidade no ponto onde se diz que Rómulo teria sido exposto. 6. Aliás, os rituais do festival tornam a sua origem ainda mais difícil de conjecturar: de facto, começam por degolar umas cabras e depois trazem à sua presença dois jovens de nascimento nobre; em seguida,

${ }^{52}$ Supra, 12.2. A etimologia apresentada para explicar Carmenta não tem fundamento filológico.

${ }^{53}$ Sacerdotes do deus Pá. 
tocam-lhes na testa com um cutelo ensanguentado, enquanto outros logo os limpam com uma toalha de lã embebida em leite; depois de serem limpos, os jovens devem soltar uma gargalhada. 7. Posteriormente, talham às tiras a pele das cabras e desatam a correr em pelo, cingidos apenas por um cinto e batendo com as tiras de couro nas pessoas que encontram; as jovens em idade de ter filhos não fogem aos açoites, pois acreditam que ajudam à gravidez e ao parto. 8. Um pormenor típico deste festival reside no facto de os Lupercos sacrificarem também um cão. Certo Butas, que escreveu em verso elegíaco sobre as origens míticas dos costumes romanos, afirma que, depois de vencerem Amúlio, os companheiros de Rómulo foram a correr, muito contentes, até ao lugar onde a loba havia amamentado os dois bebés. Dizia ainda que a festa seria uma imitação dessa corrida e que os jovens de nascimento nobre corriam

batendo nos que encontravam, como outrora, de espada em punho, de Alba vieram a correr Rómulo e Remo. ${ }^{54}$

9. Defende ainda que o cutelo banhado em sangue é aplicado na testa deles como símbolo do morticínio e do perigo então vividos, e que a purificação através do leite se faz em memória da forma como as crianças haviam sido alimentadas. Gaio Acílio, porém, narra que, antes da fundação da cidade, os rebanhos dos companheiros de Rómulo tinham desaparecido;

${ }^{54}$ Butas costuma ser identificado, com bastante probabilidade, com um liberto de Catáo, que tinha o mesmo nome. 
fizeram, então, um voto a Fauno e puseram-se a correr em busca dos rebanhos, nus, a fim de não serem molestados pelo suor. ${ }^{55}$ Será por este motivo que os Lupercos correm em pelota. 10. Se o sacrifício pretende ser uma purificação, nesse caso o cão afigura-se uma vítima adequada para servir um tal fim: de facto, os Helenos levam cachorros para os rituais de purificação e, em muitos sítios, praticam o chamado periskylakismos. ${ }^{56}$ No entanto, se tributarem antes à loba estes rituais como acção de graças por ter garantido o alimento e a sobrevivência de Rómulo, também não seria despropositado imolar um cão: na realidade, este é inimigo dos lobos. A não ser que, por Zeus, o animal se veja punido desta forma só porque incomoda os Lupercos na corrida!

22. 1. Diz-se ainda que Rómulo instituiu, pela primeira vez, o culto ao fogo, designando virgens sagradas, conhecidas por Vestais. Outros, porém, atribuem a medida a Numa, embora admitam que Rómulo fosse, de outras formas, uma pessoa extremamente religiosa e contam que seria especialista em adivinhação, a ponto de introduzir na prática divinatória o ritual do lituus; trata-se de um bastáo recurvo, com o qual os áugures delimitam as regiôes celestes, quando estão sentados a observar o voo das aves. ${ }^{57} 2$. Este objecto, que se encon-

${ }^{55}$ Gaio Acílio seria um senador romano, que se dedicou a escrever em grego sobre a história da cidade; terá dado especial atenção à origem das festividades romanas, uma vez que dois dos sete fragmentos que chegaram até nós tratam esse assunto.

${ }^{56}$ Ou seja, a imolação de cachorros como vítimas expiatórias.

${ }^{57}$ A forma do lituus faz lembrar o bastão dos pastores. 
trava guardado no Palatino, terá desaparecido quando a cidade foi tomada pelos Gauleses. Ora depois de os bárbaros haverem sido expulsos, encontrou-se o bastão, debaixo de uma grossa camada de cinza, sem nada ter sofrido com o fogo, apesar de tudo o mais ficar queimado e completamente destruído. 3. Rómulo criou também algumas leis, sendo uma delas bastante dura, pois não permite à mulher abandonar o marido, embora conceda a este repudiá-la, sob a acusação de envenenar os filhos, de falsificar as chaves ou de praticar adultério. Mas no caso de a mulher se ver rejeitada por qualquer outro motivo, dispôs então que o património do marido fosse dado em parte à mulher e em parte consagrado a Ceres. Quem repudiasse a mulher deveria oferecer sacrifícios às divindades infernais. 4. Outro aspecto peculiar consiste no facto de não ter fixado nenhuma pena para o parricida, pois definiu todo o homicídio como parricídio, classificando um como sacrilégio e o outro como um acto impossível de praticar. ${ }^{58}$ 5. E continuou a afigurar-se correcto, durante muito tempo, não reconhecer a existência deste tipo de crime. De facto, ninguém incorreu em tamanha falta em Roma durante cerca de seiscentos anos; na verdade, conta-se que o primeiro parricida foi Lúcio Hóstio, depois da guerra contra Aníbal..$^{59}$ No entanto, sobre este assunto já se discorreu o bastante.

58 Esta afirmação entende-se à luz da tradição que fazia de Numa Pompílio o criador da lei relativa ao parricídio. O facto de, na Lei das XII tábuas (9.4), o parricídio aparecer definido como assassínio de um homem em geral, talvez tenha dado a Plutarco a ideia de Rómulo não ter previsto punição para este tipo de crime.

${ }^{59}$ Por conseguinte, a seguir a 202 a.C. 
23. 1. Durante o quinto ano do reinado de Tácio, alguns familiares e parentes seus encontraram por acaso a caminho de Roma uns embaixadores de Laurento e tentaram arrancar-lhes à força os bens; porém, como eles não cediam e ofereciam resistência, acabaram por assassiná-los. 2. Ora por tratar-se de uma violência e de um crime tão grave, Rómulo era de opinião que deveriam punir imediatamente os culpados, mas Tácio andava com rodeios e procurava ganhar tempo. Na verdade, foi este o único momento em que existiu, entre eles, um claro motivo de discórdia. Em relação aos outros domínios, sempre actuaram de forma concertada entre si e, na medida do possível, tratavam dos assuntos de comum acordo e em harmonia. 3. Os familiares das vítimas, que estavam arredados de todo o processo de obter justiça por via legal, por causa da ingerência de Tácio, caíram sobre ele, numa altura em que fazia sacrifícios em Lavínio na companhia de Rómulo, e mataram-no. A Rómulo, porém, escoltaram-no entre manifestaçôes de apreço, por o terem na conta de pessoa justa. Este fez transportar ainda o corpo de Tácio e deu-lhe sepultura com todas as honras fúnebres; jaz agora no Aventino, junto do chamado Armilustrium. ${ }^{60}$ No entanto, Rómulo não fez qualquer esforço a fim de levar à justiça o homicídio. 4. E alguns historiadores contam mesmo que a cidade de Laurento entregou, por receio, os responsáveis

${ }^{60} \mathrm{O}$ Armilustrium é o nome do lugar, mas também a designação dada à festividade durante a qual se procedia à purificação do exército, pelo que o culto pode ter facultado a motivação para que se formasse a lenda relativa à morte e sepultura de Tácio. 
pelo assassínio de Tácio, mas Rómulo deixou-os partir, argumentando que a culpa do homicídio havia sido expiada com outro homicídio. 5. Isto deu origem a alguns boatos e à suspeita de que ele teria ficado contente com o afastamento do colega de governo. No entanto, estes eventos não perturbaram os Sabinos nem os fizeram revoltar-se: pelo contrário, continuaram a dar-lhe mostras de admiração, uns por benevolência para com ele, outros por receio do seu poder e outros ainda por acharem que ele gozava em tudo do favor dos deuses. 6. Rómulo era objecto de reverência também pela parte de muitos estrangeiros e os antigos Latinos enviaram-lhe embaixadores, com a proposta de firmarem um pacto de amizade e uma aliança. Tomou Fidenas, uma cidade vizinha de Roma, ao enviar de improviso - segundo sustentam alguns - os cavaleiros com ordens para cortar os gonzos às portas e aparecendo depois em pessoa, sem ninguém contar. Outros dizem que os habitantes de Fidenas foram os primeiros a lançar uma ofensiva, em caça de despojos, e a devastar a região e os arredores de Roma; Rómulo armou-lhes entâo uma emboscada, chacinou um bom número e tomou a cidade. 7. No entanto, não a arrasou nem destruiu; antes fez dela uma colónia romana, ao enviar para lá dois mil e quinhentos colonos, nos idos de Abril.

24. 1. Depois disto, abateu-se uma peste sobre a cidade, que atacava os homens de morte súbita, sem chegarem sequer a ficar doentes, e tornava as colheitas infrutíferas e os rebanhos estéreis. Caiu ainda sobre a 
cidade uma chuva de sangue, de modo que, aos males inelutáveis, se veio juntar um enorme receio supersticioso. 2. E quando idênticas calamidades atacaram também os habitantes de Laurento, todos concordaram em que fora o desrespeito pela justiça no tratamento do assassínio de Tácio e dos embaixadores que atraíra a cólera divina sobre as duas cidades. Uma vez entregues e punidos os homicidas de ambas as partes, os males cessaram de forma clara. Rómulo purificou ainda as cidades com sacrifícios expiatórios, os quais - segundo se conta - continuam a ser celebrados junto da porta Ferentina. 3. Antes de a peste se dissipar, os Camerinos atacaram os Romanos e fizeram uma razia na região, julgando-os incapazes de oferecer resistência por causa da aflição. 4. No entanto, Rómulo organizou rapidamente uma expedição contra eles e, depois de vencer o combate, deu a morte a seis mil. Tomou ainda a cidade, instalou em Roma metade dos sobreviventes e deslocou de Roma para Caméria o dobro das pessoas que lá haviam permanecido, nas calendas de Agosto. 5. Tantos eram os cidadãos que podia dispensar, passados cerca de dezasseis anos depois da fundação de Roma. Entre outros despojos, trouxe também de Caméria uma quadriga de bronze, que dedicou ao templo de Vulcano; para si, mandou fazer uma estátua com a imagem da Vitória a colocar uma coroa.

25. 1. Ao verem Roma reforçar o poderio com estas campanhas, os vizinhos mais fracos optaram por colocar-se na sua dependência e ficaram satisfeitos por 
se encontrarem em segurança, enquanto os mais fortes, por receio e inveja, achavam que não deviam tolerar tal coisa, mas antes opor-se a esse engrandecimento e humilhar Rómulo. 2. Entre os Etruscos, foram os habitantes de Veios, que ocupavam um vasto território e habitavam numa grande cidade, os primeiros a dar início às hostilidades, ao reivindicarem a entrega de Fidenas, que consideravam pertencer-lhes. $\mathrm{Na}$ verdade, isto era não só injusto como até ridículo, pois não tinham socorrido a cidade quando estava em perigo e em guerra, antes haviam permitido a chacina dos habitantes, para agora virem exigir casas e terra que pertenciam a outros. 3. Espicaçados, portanto, com os termos da resposta de Rómulo, dividiram-se em duas frentes e, enquanto uma atacava o exército estacionado em Fidenas, a outra foi ao encontro de Rómulo. Ora junto de Fidenas venceram e mataram dois mil Romanos, mas foram derrotados por Rómulo e sofreram cerca de oito mil baixas. 4. Combateu-se novamente em Fidenas e aqui todos concordam em que o mérito da vitória coube essencialmente ao próprio Rómulo, por dar mostras de grande habilidade táctica e de coragem, exibindo uma força e agilidade muito superiores ao comum mortal. Ainda assim, o relato de alguns é pela certa lendário e além do mais incrível, ao sustentar que, dos catorze mil abatidos, mais de metade havia sido morta pela mão de Rómulo em pessoa. De facto, até os Messénios deram uma certa imagem de fanfarronice, ao sustentarem que Aristómenes havia, por três vezes, oferecido sacrifícios 
por ter morto cem soldados lacedemónios. ${ }^{61}$ 5. Depois de infligir esta derrota, Rómulo deixou fugir os sobreviventes e avançou contra a própria cidade. No entanto, os habitantes não estavam em condiçôes de resistir, depois de um tão grande revés, e pediram antes a celebração de um acordo de amizade com a duração de cem anos, dando em troca uma boa parte do seu território, ao qual se atribui o nome de Septempagium, isto é a 'sétima parte', cedendo ainda as salinas existentes ao longo do rio e entregando cinquenta aristocratas como reféns. 6. Rómulo celebrou este triunfo nos idos de Outubro, exibindo, entre outros prisioneiros, também o chefe de Veios, um homem já velho, que parece ter conduzido a campanha de forma incauta e sem a experiência que se esperaria da sua idade. 7. Por este motivo, ainda hoje, ao celebrar-se uma vitória, conduzem um velho através do Fórum até ao Capitólio, envolto numa toga bordada de púrpura e com uma bola de criança presa ao pescoço, enquanto o arauto vai anunciando: «Sardianos para venda!» De facto, diz-se que os Etruscos eram antigos colonos de Sardes, e Veios é uma cidade etrusca.

26. 1. Foi esta a última batalha combatida por Rómulo. Em seguida, não conseguiu evitar o que acontece também a muitos, ou melhor, a quase todos os que se viram projectados, através de grandes e inesperados

${ }^{61}$ Aristómenes é o tradicional herói da resistência de Messénia à invasão espartana, sendo geralmente colocado na Segunda Guerra Messénica (c. 650 a.C.). Além de outros autores, também Plutarco se refere aos sacrifícios de Aristómenes em mais dois pontos da sua obra (Questóes Convivais, 660f; Banquete dos Sete Sábios, 159e). 
sucessos, para o poder e a glória. Orgulhoso dos seus feitos e tomando-se em demasiada consideração, começou a afastar-se da soberania popular e a assumir um governo monárquico, que se tornou odioso e insuportável, devido ao comportamento que ele foi o primeiro a adoptar. $^{62}$ 2. Na verdade, passou a usar um manto púrpura e uma toga bordada também a púrpura e ainda a conceder audiências recostado num trono de espaldar recurvo. À volta dele havia sempre uns jovens chamados Celeres, devido à celeridade com que desempenhavam as respectivas funçóes. ${ }^{63} 3$. Outros caminhavam à sua frente, munidos de bastóes para afastarem a multidáo, e tinham ainda correias à cintura, a fim de prenderem imediatamente quem ele designasse. Em latim mais antigo 'prender' diz-se ligare, mas agora usa-se antes o termo alligare. Daqui provém a designação de lictores para os 'portadores de varas', pois chamavam às 'varas' bacula e então serviam-se de bastôes (bakteria). 4. No entanto, afigura-se mais provável que se chamem lictores por se haver juntado um $k$ à palavra e que de início tivessem antes o nome de litores, correspondendo assim ao Grego leiturgoi. Na verdade, em Grego usa-se leiton para dizer 'público' e laos para referir o 'povo'.

${ }^{62}$ A transformação do governo de Rómulo numa tirania segue um esquema tipicamente grego de degradação progressiva, visível em sinais como a adopção de roupas luxuosas e de uma escolta pessoal, necessária por causa do carácter cada vez mais odioso do comportamento do monarca. O relato prepara, também, o contexto que conduzirá à morte de Rómulo.

${ }^{63}$ Plutarco entende este corpo como uma guarda pessoal, baseado na falsa etimologia do termo Celeres; na realidade, era antes uma antiga forma de cavalaria. 
27. 1. Quando, em Alba, morreu o seu avô $\mathrm{Nu}-$ mitor, cabia a Rómulo o reino, mas ele procurou atrair o favor do povo, ao colocar o governo nas suas mãos, designando todos os anos um magistrado para os Albanos. ${ }^{64}$ Desta forma, mostrava aos poderosos de Roma como poderiam buscar uma forma de governo autónoma e sem rei, onde fossem governados e governassem à vez. 2. Na verdade, os chamados patrícios não participavam sequer na administração dos assuntos do Estado, pois haviam ficado apenas com o título e uma situação honrosa, continuando a reunir-se em conselho mais por hábito do que para emitirem opinião. Por conseguinte, escutavam em silêncio as ordens de Rómulo e iam-se embora com a única vantagem de serem informados a respeito das suas decisóes antes da multidão. 3. As suas restantes funçóes eram ainda menos importantes. Por livre iniciativa, Rómulo decidiu repartir entre os soldados a terra conquistada pelas armas e devolver os reféns de Veios, sem procurar a anuência ou o conselho dos patrícios, dando a impressão de querer ultrajar abertamente o senado. Por isso, recaiu sobre este órgão a suspeita e a calúnia, quando Rómulo desapareceu inexplicavelmente algum tempo depois. 4. Desapareceu nas nonas do mês de Julho, como agora se designa o mês, embora

${ }^{64}$ Plutarco atribui a Rómulo a criação da dictatura, que representava uma magistratura muito importante dentro da sociedade albana. A imagem de Rómulo a antecipar um regime republicano (em contradição, de resto, com as tendências tirânicas da última fase do governo) justifica-se talvez pela sua preocupaçáo em limitar os poderes do senado. 
antes se chamasse Quintílis. ${ }^{65}$ Sobre a sua morte, nada ficou que se possa considerar seguro e seja aceite por todos, a não ser a data, sobre a qual já falei. De facto, ainda agora se realizam muitas celebraçóes naquele dia, que evocam o que então aconteceu. 5. Aliás, não há necessidade de estranhar esta incerteza. De facto, embora Cipiáo Africano tenha morrido em casa depois do jantar, não há prova nem indício claro sobre a forma como pereceu: uns dizem que foi de morte natural, pois tinha uma saúde débil; outros, que se teria suicidado com veneno; outros ainda, que os inimigos caíram sobre ele durante a noite e o sufocaram. ${ }^{66} \mathrm{E}$ no entanto, o cadáver de Cipiáo ficou à vista de todos e os que observavam o corpo podiam formular alguma suposiçáo e conjectura sobre o que teria acontecido. 6. Quanto a Rómulo, uma vez perdido o seu paradeiro, não foram mais avistados nem partes do corpo nem bocados da roupa. Ainda assim, alguns imaginaram que os senadores armaram contra ele uma conjura no templo de Vulcano e o mataram, cortando depois o corpo em pedaços, e que cada um levou um bocado para fora, ocultado nas pregas da roupa. Outros, porém, sustentam que o sumiço do corpo náo ocorreu nem no tempo de Vulcano nem na presença dos senadores, mas antes no exterior, junto do chamado Pântano da Cabra, numa altura em que Rómulo estava a presidir a uma reuniáo da assembleia,

65 Isto é, o 'quinto', fazendo o cálculo a partir de Março.

66 A morte de Cipiáo Emiliano (ou Africano menor) ocorreu de forma imprevista em 129 a.C. e sobre ela se geraram desde logo muitas especulaçóes. 
quando subitamente se observaram no céu espantosos e inefáveis fenómenos, acompanhados de incríveis transfiguraçôes. 7. De facto, a luz do sol deixou de brilhar e abateu-se uma noite - não agradável nem calma, mas antes sacudida por relâmpagos medonhos e rajadas de vento que traziam chuva de todos os lados. Entretanto, a numerosa multidão logo se dispersou em fuga, embora os nobres se mantivessem junto uns dos outros. 8. Quando cessou a agitação e a luz voltou a brilhar, o povo reuniu-se novamente no mesmo lugar e pôs-se a procurar o rei com grande ansiedade. Os nobres, porém, não permitiram que continuassem as buscas nem que se ocupassem demasiado com o ocorrido, mas antes os aconselharam a todos a honrarem e venerarem Rómulo, pois havia sido arrebatado para junto dos deuses e, de um rei excelente, tinha-se transformado em divindade benfazeja. 9. Portanto, a multidão acreditou e deu graças pelo sucedido, indo-se embora a fim de adorar o novo deus, com grandes esperanças no seu favor. Alguns, porém, avaliando a situação com acrimónia e hostilidade, confrontaram os patrícios com a acusação de enganarem o povo com histórias estúpidas e de terem morto o rei com as próprias mãos.

28. 1. Foi então que certo homem, o primeiro por nascimento entre os patrícios e o mais conceituado pelo carácter, pessoa de confiança e íntimo do próprio Rómulo, que era um dos colonos provenientes de Alba, 
Júlio Próculo de nome, ${ }^{67}$ avançou para o Fórum e, depois de jurar solenemente pelos símbolos mais sagrados, afirmou diante de todos que, numa altura em que viajava pela estrada, tinha visto Rómulo a caminhar ao seu encontro. Exibia uma aparência bela e majestosa, como não tivera nunca antes, e vinha guarnecido com armas resplandecentes e fulgurantes. E ele, deslumbrado com tal aparição, exclamou: 2. "Ó rei, que te aconteceu e que desígnio era o teu, para nos abandonares a braços com acusaçóes injustas e malévolas, e deixares toda a cidade órfẫ e mergulhada numa dor imensa?» Rómulo deu a seguinte resposta: «Aos deuses aprouve, Próculo, que eu passasse este período em companhia dos humanos e viesse a fundar uma cidade destinada a ser a maior pelo poder e pela glória, e tornasse a viver nos céus, de onde provim. 3. Mas agora adeus; vai contar aos Romanos que, se eles observarem o bom senso juntamente com a coragem, hão-de atingir o cume da valentia humana. E para vós ficarei como Quirino, uma divindade benfazeja.» Estas palavras pareceram aos Romanos dignas de confiança, devido à reputação de quem as proferira e ao julgamento feito; além disso, foram invadidos por um sentimento sagrado, idêntico à inspiração divina. E assim, ninguém contradisse Próculo e todos puseram de lado a desconfiança e a calúnia, optando antes por rezar a Quirino e venerá-lo como um deus. 4. Na verdade, estes eventos assemelham-se aos relatos míticos dos Gregos relativos a Arísteas do Proconeso e a Cleomedes de

${ }^{67}$ A figura de Júlio Próculo ajuda a reforçar a ligação entre os primeiros Romanos e as mais antigas e ilustres famílias albanas. 
Astipaleia. ${ }^{68}$ De facto, conta-se de Arísteas que morreu numa lavandaria e que o seu corpo, quando os amigos foram procurá-lo, tinha desaparecido sem deixar rasto; entretanto, certas pessoas que regressavam de viagem afirmavam tê-lo visto a caminho de Crotona. 5. Quanto a Cleomedes, uma pessoa que se distinguia pela força e estatura gigantesca, e também pela estupidez de um carácter dado a excessos, diz-se que tinha praticado já muitos actos de violência até que, finalmente, numa escola para crianças, bateu com o punho na coluna que sustentava o tecto, partiu-a ao meio e fez desabar o edifício. 6. As crianças morreram e ele, vendo-se perseguido, refugiou-se numa grande caixa e fechou a tampa, segurando-a por dentro com tamanho alento que, mesmo com muitos a puxar com toda a força e à uma, não foram capazes de abri-la. Quando, finalmente, desfizeram a caixa, não conseguiram encontrar o homem, nem vivo nem morto. Então, aturdidos pelo espanto, enviaram mensageiros a Delfos, aos quais a Pítia deu a seguinte resposta:

O derradeiro herói, Cleomedes de Astipaleia.

7. Conta-se ainda que o cadáver de Alcmena também se tornara invisível, durante o cortejo fúnebre, e

${ }^{68}$ Arísteas é apresentado pela tradição como sendo um taumaturgo, a quem se atribuía uma obra poética, na qual apareciam misturados elementos fantásticos e etnográficos. Em geral, as fontes situam-no durante o tempo de Creso (séc. VI a.C.). Quanto a Cleomedes, aparece registado como vencedor na prova de pugilato, nas Olimpíadas de 492 a.C. 
que aparecera uma pedra no esquife. Em suma, relatam -se muitas lendas com o mesmo teor, que, contra toda a probabilidade, procuram elevar a natureza humana à estatura divina. ${ }^{69}$ Em todo o caso, seria ímpio e ignóbil rejeitar inteiramente o carácter divino da virtude humana, da mesma forma que seria insensato misturar céu e terra. 8. Por conseguinte, quem quiser ficar pelo seguro, deve dizer com Píndaro: ${ }^{70}$

O corpo de todo o homem segue a morte inelutável, mas deixa ainda a viver uma imagem da vida, pois ela somente dos deuses provém.

De facto, deles provém e a eles retorna, não com o corpo, mas quando se separa dele e se liberta, tornando-se totalmente pura, sem carne e imaculada. 9. Na verdade, segundo Heraclito, «a alma seca é a mais perfeita, pois evola-se do corpo tal como o relâmpago da nuvem $»^{71}$. Mas a alma embebida no corpo e por ele circundada é como uma exalação pesada e obscura, lenta a desembaraçar-se e lenta a elevar-se. 10. Não é, portanto, necessário forçar a natureza para fazer subir aos céus o corpo das pessoas de bem, mas pode-se crer com segurança que as suas virtudes e almas, de acordo com a

${ }^{69}$ Plutarco mostra-se bastante céptico em relação ao costume grego e romano de registar a apoteose de heróis, reduzindo, assim, as possibilidades de contactos directos entre deuses e humanos a uma ascensão gradativa autorizada pela verdade dos factos e pelo bom senso.

${ }^{70}$ Frg. 131 b Snell.

${ }^{71}$ Frg. 118 Diels-Kranz. 
natureza e com a justiça divina, ascendam da condição humana à de heróis, de heróis a semi-deuses e, finalmente, que de semi-deuses - como na iniciação mistérica, depois de se purificarem e santificarem, libertando-se de todos os elementos mortais e sensíveis - sejam elevadas a deuses. Contudo, isso não acontece por decreto da cidade, mas segundo a verdade e a lógica aceitável, desta forma atingindo o fim mais belo e mais ditoso.

29. 1. Quanto ao sobrenome de Quirino, atribuído a Rómulo, alguns explicam-no como sendo equivalente a Eniálio, ${ }^{72}$ outros por os cidadãos se chamarem Quirites; segundo outros ainda, deriva do facto de os antigos designarem por quiris a ponta da haste ou mesmo a lança inteira: por isso, deram o epíteto de Quiritis à estátua de Juno apoiada sobre uma lança e a designação de Marte à haste consagrada na Régia, ${ }^{73}$ além de que recompensam com uma lança a pessoa que se distinguir em combate. Por conseguinte, Rómulo ficou conhecido por Quirino, devido ao facto de ser uma divindade "marcial" ou "equipada com lança". 2. Em todo o caso, foi-lhe dedicado um templo no monte Quirinal, cujo nome deriva a partir dele. $\mathrm{O}$ dia em que desapareceu chama-se 'fuga do povo' (Poplifugium) e Nonae Capratinae, pois nesta altura o povo sai da cidade para fazer um

72 À letra 'belicoso'; constitui um dos epítetos específicos de Marte.

${ }^{73}$ Antigo palácio atribuído a Numa Pompílio, que passou depois a ser a residência do Pontifex Maximus; a hasta Martis encontrava-se no sacrarium Martis aí existente. Também sobre a Régia, vide supra 18.9. 
sacrifício no Pântano da Cabra; de facto, a palavra latina para 'cabra' é capra. ${ }^{74} 3$. Enquanto se dirigem para o sacrifício, vão gritando em alta voz muitos nomes locais, como Marco, Lúcio, Gaio, em memória do que acontecera naquele dia, e clamando uns pelos outros com receio e apreensão. 4. Contudo, alguns acham que se trata não da representação de uma fuga, mas antes da pressa e urgência, que explicam da maneira seguinte. Depois de os Gauleses tomarem Roma e de serem rechaçados por Camilo, a cidade encontrava-se fragilizada e incapaz de facilmente se levantar por si mesma, pelo que muitos Latinos aproveitaram para fazer uma expedição contra ela, com Líbio Postúmio no comando. 5. Depois de estacionar o exército não muito longe de Roma, este enviou um arauto com a proposta de que os Latinos desejavam reanimar o antigo acordo de boa vizinhança e parentesco, que se tinha entretanto deixado cair, através de um reforço de novos casamentos entre os dois povos. 6. Portanto, se lhes enviassem bastantes donzelas e as mulheres sem marido, haveria paz e amizade entre si, como acontecera já com os Sabinos, em termos idênticos. Depois de escutarem a mensagem, os Romanos ficaram com receio da guerra, mas eram de opiniáo que a entrega das mulheres não constituía uma pena mais leve que o cativeiro. 7. Enquanto estavam com estas hesitações, uma escrava de nome Filótis (a que alguns dão

${ }^{74}$ As duas festas agora referidas celebravam-se a 5 e a 7 de Julho, respectivamente, e embora Plutarco as apresente unidas, tinham uma origem diversa, se bem que já sujeita a discussão na antiguidade, como o próprio biógrafo também regista. 
antes o nome de Tútola) aconselhou-os a não fazerem nenhuma das duas coisas, mas a servirem-se antes do dolo para fugir tanto à guerra como à entrega de reféns. $\mathrm{O}$ plano consistia no seguinte: enviar aos inimigos a própria Filótis, juntamente com outras servas de bela figura, arranjadas como se mulheres livres fossem. Depois, durante a noite, Filótis daria sinal com uma tocha e os Romanos avançariam armados, surpreendendo os adversários durante o sono. 8. Assim procederam e os Latinos de nada desconfiaram. Filótis fez então sinal do alto de uma figueira-brava, mas encobrindo a tocha com véus e mantos, de maneira a que a luz não ficasse à vista dos oponentes, mas fosse bem visível para os Romanos. Mal avistaram a chama, saíram logo a toda a pressa e, por causa da urgência, iam-se chamando uns aos outros repetidas vezes, junto das portas. 9. Caíram, entáo, de surpresa sobre os inimigos e levaram-nos de vencida. Celebram agora uma festa para comemorar a vitória, à qual chamam Nonae Capratinae, por causa da figueira-brava, a que os Romanos dão o nome de caprificus, e durante a qual as mulheres comem ao ar livre, à sombra de ramos de figueira. 10. Quanto às escravas, passeiam-se em grupos pela cidade, enquanto se divertem, e depois trocam sapatadas entre si e atiram pedras umas às outras, em memória do facto de outrora haverem ajudado os Romanos e com eles partilhado os perigos do combate. 11. Contudo, entre os historiadores não muitos aceitam este relato; na verdade, o facto de se chamarem uns aos outros pelo nome durante o dia e de se dirigirem ao Pântano da Cabra a fim de celebrarem 
um banquete parece estar mais de acordo com a primeira versáo dos acontecimentos, a não ser que - por Zeus - estes eventos hajam ocorrido no mesmo dia, mas em épocas distintas. 12. Conta-se que, ao desaparecer de entre os homens, Rómulo teria cinquenta e quatro anos de idade e trinta e oito de reinado. 


\section{Comparação entre Teseu e Rómulo}

1. 1. São estas, portanto, as notícias dignas de memória que me foi possível reunir, relativamente a Rómulo e a Teseu. Ora torna-se evidente, em primeiro lugar, que, por espontânea vontade e sem ninguém o forçar a isso, já que poderia ter permanecido calmamente a reinar em Trezena como herdeiro de um trono nada inglorioso, Teseu preferiu realizar grande feitos por iniciativa própria. Quanto a Rómulo, foi para escapar à servidão efectiva e à vingança iminente que, para dizer como Platão, ${ }^{75}$ "se tornou corajoso simplesmente por medo", e foi também por receio de sofrer o suplício extremo que se viu compelido a realizar obras notáveis. 2. Em seguida, a sua maior empresa consistiu em eliminar um único tirano, o de Alba; todavia, para Teseu, banir Círon, Sínis, Procrustes e Corinetes foi apenas uma tarefa acessória e preliminar: ao derrubar e punir estas pessoas, livrou a Hélade de terríveis tiranos, antes mesmo de ser reconhecido pelos que tinha salvado. 3. Para mais, este poderia viajar por mar sem incómodos e sem temer ataques de piratas, ao passo que Rómulo não conseguia evitar o perigo enquanto Amúlio fosse vivo. E há fortes provas disso mesmo: de facto, Teseu, embora não fosse pessoalmente vítima de nenhuma injustiça, lançou-se contra os malfeitores em defesa dos outros; Rómulo e Remo, pelo contrário, enquanto nada sofreram do tirano, suportaram vê-lo a ser injusto com toda a gente. 4. E se, por um lado, foi gran-

${ }^{75}$ Fédon, 68d. A citação é feita de memória e não reproduz o texto platónico, embora se mantenha fiel ao sentido geral. 
de a proeza de Rómulo, ao ser ferido em combate com os Sabinos, ao matar Ácron e ao vencer na batalha muitos outros inimigos, também se torna necessário comparar estes feitos com as lutas de Teseu contra os Centauros e as Amazonas. 5. E quanto à coragem evidenciada a propósito do tributo a Creta - quer consistisse em tornar-se alimento para uma fera, quer em ser sacrificado sobre o túmulo de Andrógeo, quer ainda (e esta é a mais leve das variantes da história) em servir como escravo homens insolentes e cruéis, entregando-se a uma dependência inglória e humilhante -, foi ainda assim por vontade própria que embarcou com as donzelas e os jovens rapazes. Não há palavras para traduzir tamanha audácia, magnanimidade e sentido de justiça em relação à comunidade ou ainda um tal apreço pela glória e pela virtude. 6. Desta forma, não me parece que os filósofos errem, quando definem o amor como «um auxílio dos deuses, para o cuidado e salvação dos jovens». ${ }^{76} \mathrm{Na}$ verdade, o amor de Ariadne afigura-se, mais do que outra coisa qualquer, obra divina e um expediente para garantir a salvação de Teseu. 7. E não é caso para censurá-la por estar enamorada, mas antes para admirar que todos os homens e todas as mulheres não fossem tomados por igual sentimento: se foi ela a única a experimentar esta paixão, então parece-me que foi também absolutamente merecedora do amor de um deus, pois amava o belo, o bom e as melhores qualidades de um homem.

${ }^{76}$ Afirmação de Pólemon, segundo a citação que dele faz o mesmo Plutarco nos Moralia (780d). Este estudioso esteve à frente da Academia platónica entre 314 e 265 a.C. 
2. 1. Embora ambos fossem, por natureza, pessoas talhadas para o governo, nenhum manteve até ao fim o regime monárquico, acabando por fazer desvios e alteraçóes: um para a democracia, o outro para a tirania, cometendo assim o mesmo erro, ainda que por vias opostas. 2. Na verdade, quem governa tem de salvaguardar, em primeiro lugar, o próprio governo: ora isso consegue-se tanto a afastar o que é inconveniente como a proteger o que convém. 3. Quem diminui ou expande o poder, não continua rei nem governante, pois torna-se num demagogo ou num déspota, assim despertando ou o ódio ou o desprezo dos governados. Em todo o caso, o primeiro erro parece derivar da bondade e da filantropia, enquanto o segundo resulta do egoísmo e da severidade.

3. 1. Ora se as desgraças humanas não podem ser consideradas apenas responsabilidade divina, mas a sua causa deve buscar-se também nos diferentes caracteres e paixôes de cada um, então nenhum deles poderá ser absolvido por haver agido com ânimo irreflectido e com ira apressada e imprudente, um em relação ao irmão e o outro em relação ao filho. No entanto, ao analisarmos o motivo que lhes alterou o ânimo, tem maior desculpa o que sofreu maior provocação, como acontece com a pessoa que é derrubada por um golpe mais forte. 2 . De facto, no caso de Rómulo a desavença gerou-se no momento em que se discutia e analisava o bem comum, pelo que não houve motivo razoável para passar da razão a um tal impulso. Quanto ao comportamento de 
Teseu em relação ao filho, foi induzido a errar por amor, por ciúme e pelas insídias de uma mulher, às quais poucas pessoas conseguem escapar totalmente. 3. E o factor mais importante é que a exaltação de Rómulo o fez incorrer num acto e num gesto de que náo resultou nenhum final feliz; quanto à ira de Teseu, não foi além de palavras, afrontas e imprecaçóes ditadas pela velhice, uma vez que as outras desgraças parecem ter acontecido por acaso ao jovem. Por esta ordem de razóes, seria caso para se dar a Teseu os votos de preferência.

4. 1. Rómulo tem, contudo, em primeiro lugar, o mérito de haver atingido a notoriedade a partir de inícios muito modestos. 2. De facto, embora Rómulo e Remo fossem considerados escravos e filhos de porqueiros antes de se tornarem livres, libertaram da servidão quase todos os Latinos e, de uma só vez, granjearam muitos dos mais belos títulos de glória: serem matadores de inimigos, salvadores de familiares, reis de povos e fundadores de cidades - e não propriamente transferidores de residências como foi o caso de Teseu, que juntou e fundiu diferentes povoaçóes numa única, destruindo muitas cidades cuja designação derivava do nome de reis e antigos heróis. 3. Rómulo tomou essas medidas mais tarde, ao forçar os inimigos a abater e destruir as próprias casas, a fim de irem viver com os conquistadores. No início, porém, não transferiu nem alargou uma cidade já existente, antes a construiu a partir do nada, sendo obrigado a lutar ele mesmo e de uma só vez por conseguir uma terra, uma pátria, um reino, 
estirpes, casamentos e relaçóes de parentesco; não abateu nem eliminou ninguém, mas de bom grado acolheu os que não tinham casa nem lar e desejavam ser contados entre o povo e os cidadáos. 4. Não matou ladróes nem malfeitores, mas submeteu naçóes pela guerra, aniquilou cidades e triunfou sobre reis e comandantes.

5. 1. Para mais, quanto à desventura de Remo, discute-se sobre quem terá sido o autor material do crime e grande parte da responsabilidade vem atribuída a outros. Em todo o caso, foi claramente ele quem salvou a mãe da completa destruição e colocou no trono de Eneias o avô, que levava uma existência de sujeição inglória e desonrosa, além de lhe ter prestado bons serviços de espontânea vontade e de nunca o haver prejudicado, mesmo sem querer. 2. Creio, no entanto, que o esquecimento e negligência de Teseu relativamente à ordem de desfraldar a vela dificilmente o poderiam livrar da acusação de parricídio, por mais hábil que fosse a defesa e maior a clemência dos juízes. Ao constatar que seria extremamente penosa a tarefa dos eventuais defensores de Teseu, certo autor ático pôs-se a especular que Egeu, na ânsia de correr para a acrópole a fim de ver o navio que se aproximava, terá tropeçado e caído, como se fosse de admitir que ele andasse sem escolta ou consigo náo tivesse um servo enquanto se apressava em direcção ao mar.

6. 1. Quanto ao rapto das mulheres, as transgressóes necessitariam de uma justificação mais digna no 
caso de Teseu. Antes de mais, porque ocorreram muitas vezes: de facto, raptou Ariadne, Antíope, Anaxo de Trezena e ainda por cima Helena, numa altura em que ele tinha passado já os melhores anos e ela ainda os não havia atingido, pois continuava a ser uma rapariguita de verdes anos, enquanto ele passara já a idade de casar, mesmo segundo a lei. Em segundo lugar, devido aos pretextos aduzidos: na verdade, as atenienses que descendiam de Erecteu e de Cécrops não eram menos dignas de lhe gerar descendência do que as filhas dos Trezénios, dos Lacónios e das Amazonas, tomadas aliás sem matrimónio legítimo. 2. Surge, por conseguinte, a suspeita de que ele terá procedido assim movido por prepotência e por luxúria. Contudo, Rómulo, antes de mais, apesar de ter raptado quase oitocentas mulheres, ${ }^{77}$ não as guardou a todas para si mas apenas Hersília, segundo se conta, repartindo as restantes pelos cidadáos que náo estavam casados. Mais tarde e na sequência destes acontecimentos, o respeito, amor e correcção que observaram no trato com as mulheres transformaram aquela violência e injustiça no acto mais belo e politicamente mais proveitoso para a comunidade. 3. E assim, misturou-os uns com os outros e fundiu os dois povos, preparando o Estado para a torrente futura de abundância e poder. E quanto ao pudor, amizade e firmeza que logrou incutir nos matrimónios, pode servir de testemunha o tempo. 4. De facto, em duzentos e trinta anos, nenhum homem ousou abandonar a esposa, nem mulher alguma deixou

${ }^{77} \mathrm{Na}$ biografia de Rómulo (supra, 14.7), Plutarco apresenta números um pouco inferiores. 
o convívio com o marido; e tal como, entre os Helenos, os mais cultos sabem dizer quem foi a primeira pessoa a cometer parricídio e matricídio, também todos os Romanos estáo conscientes de que Carvílio Espúrio foi o primeiro a repudiar a esposa, sob a alegação de esterilidade. $^{78} 5$. E para além deste alargado espaço temporal, aduzem um testemunho favorável também os próprios factos. Na verdade, graças à prática dos casamentos mistos, os reis partilharam um mesmo governo e as estirpes uma única cidadania. Pelo contrário, os esponsais de Teseu não trouxeram aos Atenienses nem amizades nem pactos de aliança com ninguém, mas antes ressentimentos e guerras, assassínios de cidadãos e, por último, a perda de Afidnas. Aliás, só devido à compaixão dos inimigos - quando perante eles se prostraram e os invocaram como deuses - é que não sofreram o mesmo castigo que os Troianos por causa de Alexandre. 6. Ainda assim, a mãe de Teseu não só ficou exposta ao perigo, como ainda sofreu as penas de Hécuba, ao ver-se abandonada e esquecida pelo filho - a menos que a história do cativeiro seja uma invenção, e pode muito bem ser falso tanto este elemento como boa parte dos restantes. 7. Por exemplo, as lendas relativas à intervenção divina

78 Trata-se de um cidadáo romano, que foi cônsul em 234 e 228, tendo morrido em 211 a.C. Na verdade, há aqui um erro cronológico, pois contando duzentos e trinta anos a partir de Rómulo, chega-se apenas ao reinado de Tarquínio Soberbo. A falha deve ter resultado da confusão entre dois episódios distintos: um relativo ao primeiro divórcio de esposos e outro referente ao primeiro conflito entre nora e sogra; este último deu-se no tempo de Tarquínio e o anterior no tempo de Carvílio. Plutarco refere-se a ambos os eventos na Comparação entre Licurgo e Numa (3.7). 
nas suas vidas apresentam enormes diferenças: de facto, a salvação de Rómulo aconteceu por favor expresso dos deuses; já o oráculo dado a Egeu, que o proibia de aproximar-se de uma mulher enquanto estivesse em terra estrangeira, parece demonstrar que o nascimento de Teseu se verificou contra os desígnios divinos. 


\section{BibLIOGRAFIA}

\section{EDiçÓES, TRADUÇÓES E COMENTÁRIOS}

Ampolo, Carmine \& Manfredini, Mario: Plutarco. Le Vite di Teseo e di Romulo (Milano, Fondazione Lorenzo Valla, $\left.{ }^{2} 1993\right)$.

Bettalli, Marco \& Vanotti, Gabriella: Plutarco. Vite Paralelle. Teseo - Romolo (Milano, Biblioteca Universale Rizzoli, 2003).

Flacelière, R., Chambry, É. \& Juneaux, M.: Plutarque. Vies I. Thésée - Rumulus, Lycurgue - Numa (Paris, Coll. G. Budé, 1957).

Pérez Jiménez, Aurelio: Plutarco. Vidas Paralelas. I. TeseoRómulo, Licurgo - Numa (Madrid, Gredos, 1985).

Perrin, Bernadotte: Plutarch's Lives. Theseus and Romulus, Lycurgus and Numa, Solon and Publicola (Harvard, University Press, 1967).

Ziegler, K.: Plutarchi Vitae Parallelae (Leipzig, Teubner, I959-I97I).

\section{Estudos}

Ampolo, Carmine, "La paideia degli eroi fondatori Leducazione e la giovinezza nelle Vite di Teseo e di Romolo", in J. R. Ferreira (coord.), Plutarco educador da Europa (Porto, Fundação Eng. António de Almeida, 2002) 281-292. 
BRIQUeL, D.: "Perspectives comparatives sur la tradition relative à la disparition de Romulus", Latomus 36 (1977) 253-282.

Cornell, T. J.: The Beginnings of Rome (London, Routledge, 1995).

Duff, T.: Plutarch's Lives. Exploring Virtue and Vice (Oxford, University Press, 1998) cap. 8.

Edlund, I. E. M.: "Must a king die? The death and disappearance of Romulus”, PP 39 (1984) 401-408.

Erbse, H.: "Die Bedeutung der Synkrisis in den Parallelbiographien Plutarchs", Hermes 84 (1956) 398-424.

Fialho, Maria do Céu: "Teseu em Plutarco à luz da tradição”, in J. R. Ferreira (coord.), Plutarco educador da Europa (Porto, Fundação Eng. António de Almeida, 2002) 67-79.

- "Philanthrôpia and Philautia in Plutarch's Theseus", Hermathena, 182 (2007) 71-83.

Flacelière, R.: "Sur quelques passages des Vies de Plutarque. I. Thésée - Romulus”, REG 61 (1948) 67 -103 .

Larmour, David H. J.: "Plutarch's compositional methods in the Theseus and Romulus", TAPhA 118 (1988) 361-375.

LEÃo, Delfim F.: "Alexandre Magno: da estratégia pan -helénica ao cosmopolitismo", in A. Casanova 
(coord.), Atti del convegno internazionale di studi "Plutarco e l'età ellenistica" (Firenze, Università degli Studi di Firenze, 2005a) 23-37.

— "Cidadania e exclusão: mecanismos de gradação identitária”, in M. C. Fialho, M. F. Sousa e Silva $\&$ M. H. da Rocha Pereira (coords.), O desenvolvimento da ideia de Europa. Vol. I De Homero ao fim da Época Clássica (Coimbra, Imprensa da Universidade, 2005b) 43-75.

Jones, C. P.: Plutarch in Rome (Oxford, University Press, 1971).

Pelling, Christopher B. R.: " "Making myth look like history»: Plato in Plutarch's Theseus-Romulus", in A. Pérez Jiménez, J. García López \& R. M. Aguilar (eds.), Plutarco, Platón y Aristóteles. Actas del V Congreso Internacional de la I.P.S. (Madrid, Ediciones Clásicas, 1999) 431-443.

PÉrez Jiménez, Aurelio: "Actitudes del hombre frente a la Tyche en las Vidas Paralelas de Plutarco", BIEH 7 (1973) 101-110.

Portela, J.: As Amazonas no Mundo Grego (Coimbra, Fac. Letras, diss. Mestrado, 2002).

Rodrigues, Nuno Simóes: Mitos e lendas - Roma antiga (Lisboa, LivroseLivros, 2005).

Titchener, F. B.: "Critical trends in Plutarch's Roman Lives, 1975-1990", ANRW II. 33.6 (1992) 4128 -4153 , esp. 4131-4133. 

OBRA PUBLICADA

COM A COORDENAÇÁO

CIENTÍFICA

0

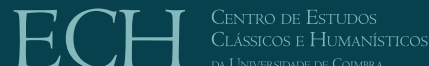

DA UNIVERSTIDAD DE COIMBRA

- $\mathbf{U}$

C •

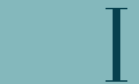

IMPRE VSA DA UNIVERSIDADE DE COINPRA 